NUREG/CR-6390

PNL-10806

\title{
Radiological Characterization of Spent Control Rod Assemblies
}

\author{
RECEIVED \\ NOV -71995 \\ OSTI
}

Prepared by

E. A. Lepel, D. E. Robertson, C. W. Thomas, S. L. Pratt, D. L. Haggard

Pacific Northwest Laboratory

Operated by

Battelle Memorial Institute

Prepared for

U.S. Nuclear Regulatory Commission 


\section{AVAILABILITY NOTICE}

Availability of Reference Materials Cited in NRC Publications

Most documents cited in NRC publications will be available from one of the following sources:

1. The NRC Public Document Room, 2120 L Street, NW., Lower Level, Washington, DC 20555-0001

2. The Superintendent of Documents, U.S. Government Printing Office, P. O. Box 37082 , Washington, DC 20402-9328

3. The National Technical Information Service, Springfield, VA 22161-0002

Although the listing that follows represents the majority of documents cited in NRC publications, it is not intended to be exhaustive.

Referenced documents available for inspection and copying for a fee from the NRC Public Document Room include NRC correspondence and internal NRC memoranda: NRC bulletins, circulars, information notices, inspection and investigation notices; licensee event reports; vendor reports and correspondence; Commission papers; and applicant and licensee documents and correspondence.

The following documents in the NUREG series are available for purchase from the Government Printing Office: formal NRC staff and contractor reports, NRC-sponsored conference proceedings, international agreement reports, grantee reports, and NRC booklets and brochures. Also available are regulatory guides, NRC regulations in the Code of Federal Regulations, and Nuclear Regulatory Commission Issuances.

Documents available from the National Technlcal Information Service include NUREG-series reports and technical reports prepared by other Federal agencies and reports prepared by the Atomic Energy Commission, forerunner agency to the Nuclear Regulatory Commission.

Documents available from public and special technical libraries include all open literature items, such as books. Journal articles, and transactions Federal Register notices, Federal and State legislation, and congressional reports can usually be obtained from these libraries.

Documents such as theses, dissertations, foreign reports and translations, and non-NRC conference proceedings are available for purchase from the organization sponsoring the publication cited.

Single copies of NRC draft reports are available free, to the extent of supply. upon written request to the Office of Administration, Distribution and Mall Services Section, U.S. Nuclear Regulatory Commission, Washington, DC 20555-0001.

Copies of industry codes and standards used in a substantive manner in the NRC regulatory process are maintained at the NRC Library, Two White Flint North, 11545 Rockville Pike, Rockville, MD 20852-2738, for use by the public. Codes and standards are usually copyrighted and may be purchased from the originating organization or, if they are American National Standards, from the American National Standards Institute. 1430 Broadway, New York, NY 10018-3308.

\section{DISCLAIMER NOTICE}

This report was prepared as an account of work sponsored by an agency of the United States Government. Neither the United States Government nor any agency thereof, nor any of their employees, makes any warranty, expressed or implied, or assumes any legal liability or responsibility for any third party's use, or the results of such use, of any information, apparatus, product, or process disclosed in this report, or represents that its use by such third party would not infringe privately owned rights. 
NUREG/CR-6390

PNL-10806

\section{Radiological Characterization of Spent Control Rod Assemblies}

Manuscript Completed: September 1995

Date Published: October 1995

Prepared by

E. A. Lepel, D. E. Robertson, C. W. Thomas, S. L. Pratt, D. L. Haggard

Pacific Northwest Laboratory

Richland, WA 99352

C. Feldman, NRC Project Manager

Prepared for

Division of Regulatory Applications

Office of Nuclear Regulatory Research

U.S. Nuclear Regulatory Commission

Washington, DC 20555-0001

NRC Job Code B2880 


\section{DISCLAIMER}

Portions of this document may be illegible electronic image products. Images are produced from the best available original document. 


\begin{abstract}
This document represents the final report of an ongoing study to provide radiological characterizations, classifications, and assessments in support of the decommissioning of nuclear power stations. Earlier studies addressed the characterization of residual radionuclide contamination deposited throughout nuclear power stations (Abel, et al., 1986; Robertson, et al., 1991; Rohertson, et al., 1993). Later work included the detailed analyses of neutron-activated metal waste (e.g., spent fuel assembly hardware and reactor pressure vessel steel) removed from reactor pressure vessels (Robertson, et al., 1991;

Robertson, et al., 1993). This report describes the results of non-destructive and laboratory radionuclide measurements, as well as waste classification assessments, of BWR and PWR spent control rod assemblies which are typical of those being shipped to commercial low-level waste disposal facilities. The BWR spent Control Rod Blade (CRB) was a General Electric cruciform control rod from Duane Arnold Energy Center. The two types of PWR spent control rods were a Westinghouse Rod Cluster Control Assembly (RCCA) and a Bumable Poison Rod Assembly (BPRA), both from Point Beach 1 Nuclear Station. The radionuclide inventories of these spent control rods were determined by three separate methodologies, including I) direct assay techniques, 2) calculational techniques, and 3 ) by sampling and laboratory radiochemical analyses. For the CRB and the BPRA, ${ }^{60} \mathrm{Co}$ and ${ }^{63} \mathrm{Ni}$, present in the stainless steel cladding, were the most abundant neutron activation products. The boron carbide and the borosilicate glass neutron absorption materials contained insignificant radionuclide inventories compared to the stainless steel. The most abundant radionuclide in the RCCA was ${ }^{108 m} \mathrm{Ag}$ ( 130 year halflife) produced in the $\mathrm{Ag}$-In-Cd alloy used as the neutron poison. This radionuclide will be the dominant contributor to the gamma dose rate for many hundreds of years. The results of the direct assay methods, utilizing gamma spectrometry/TLD dosimetry/dose-to-Curie conversions, agreed very well $( \pm 10 \%)$ with the sampling/radiochemical measurements, thus lending confidence to the presently employed direct assay methodology used by the utilities and vendors for determining Curie contents of neutron-activated metal waste components. The results of the calculational methods agreed fairly well with the empirical measurements for the BPRA, but often varied by a factor of 5 to 10 for the CRB and the RCCA assemblies. Because of the large quantities of neutron poison material in the control rods and the uncertainties in their exact locations relative to the reactor core over their operating histories, it is difficult to accurately calculate the radionuclide inventories in these components. If concentration averaging and encapsulation, as allowed by 10CFR61.55, is performed, then each of the entire control assemblies would be classified as Class $\mathrm{C}$

low-level radioactive waste. These studies have provided important information and data relative to the waste disposal considerations associated with nuclear power station decommissioning.
\end{abstract}





\section{Contents}

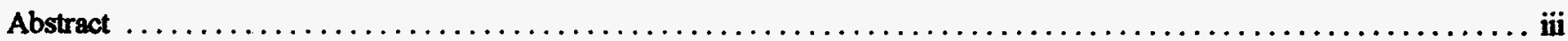

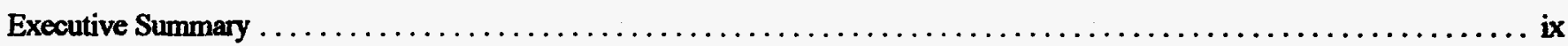

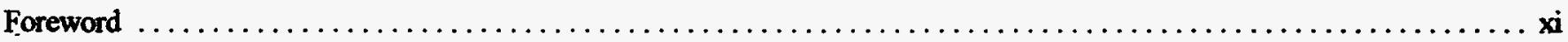

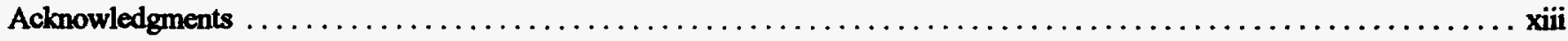

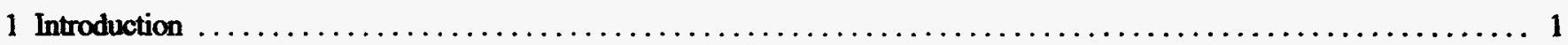

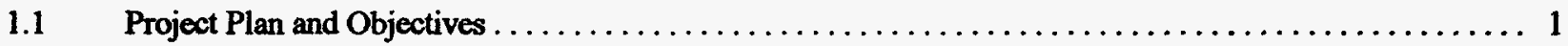

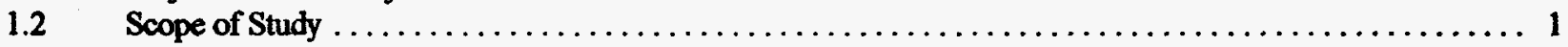

1.3 Waste Disposal Options for Neutron Irradiated Components Associated with Reactor Decommissioning ... 1

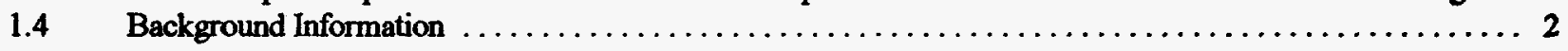

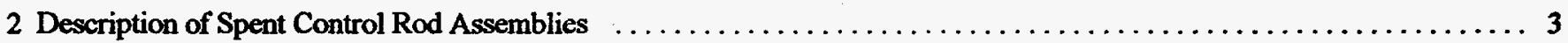

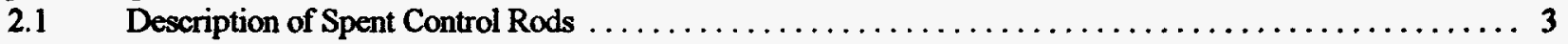

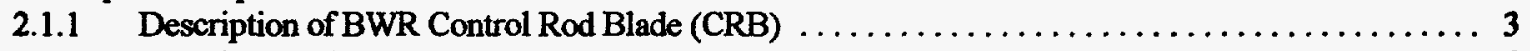

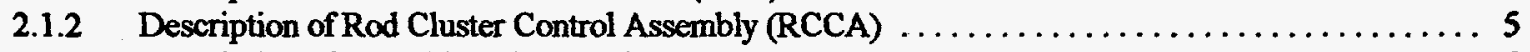

2.1.3 Description of Burnable Poison Rod Assembly (BPRA) $\ldots \ldots \ldots \ldots \ldots \ldots \ldots \ldots \ldots$

3 Description of Direct-Assay Methods to Determine Curie Content $\ldots \ldots \ldots \ldots \ldots \ldots \ldots \ldots \ldots \ldots \ldots \ldots \ldots \ldots \ldots$

3.1 Gamma Spectrometry and Dose- to-Curie Conversions $\ldots \ldots \ldots \ldots \ldots \ldots \ldots \ldots \ldots \ldots \ldots, \ldots$

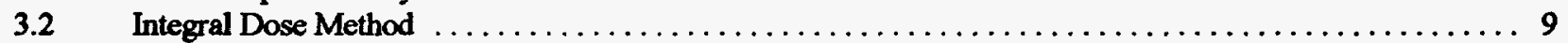

3.3 Results of the Two Direct Assay Methods $\ldots \ldots \ldots \ldots \ldots \ldots \ldots \ldots \ldots \ldots \ldots \ldots \ldots$

4 Radiological and Stable Element Characterization of Control Rod Samples $\ldots \ldots \ldots \ldots \ldots \ldots \ldots \ldots \ldots \ldots \ldots \ldots, 13$

4.1 Description of Samples Obtained for Radiochemical Analysis $\ldots \ldots \ldots \ldots \ldots \ldots \ldots \ldots \ldots \ldots \ldots 13$

4.2 Description of Sample Preparation for Radiochemical and Stable Element Analysis $\ldots \ldots \ldots \ldots \ldots \ldots \ldots$

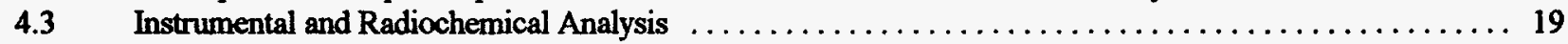

4.3.1 Analysis of Metal Samples from the Control Rods $\ldots \ldots \ldots \ldots \ldots \ldots \ldots \ldots \ldots \ldots$

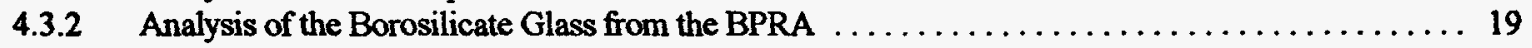

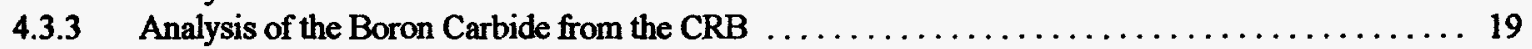

4.4 Radioanalytical Results from Three Spent Control Rods $\ldots \ldots \ldots \ldots \ldots \ldots \ldots \ldots \ldots \ldots \ldots \ldots \ldots$

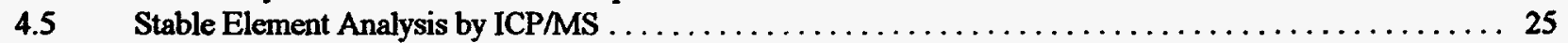

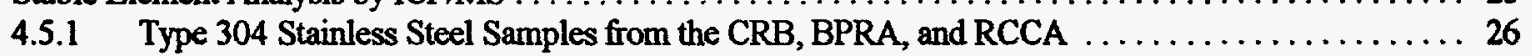

4.5.2 Ag-In-Cd Metal Sample from the RCCA ............................... 26

4.5.3 Boron Carbide from the Control Rod Blade (CRB) Samples $\ldots \ldots \ldots \ldots \ldots \ldots \ldots \ldots \ldots \ldots$

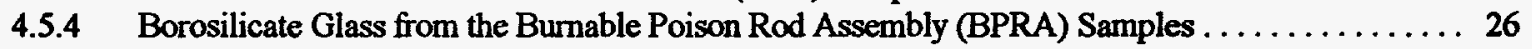

4.6 Comparison to Other Reported Radioanalytical Measurements . . . . . . . . . . . . . . . . . . . . 26

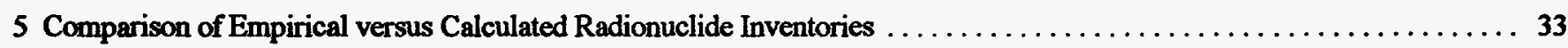

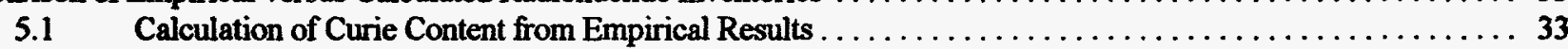

5.2 Comparison of Empirical vs. Calculated Radionuclide Concentrations in Control Rods ........... 34

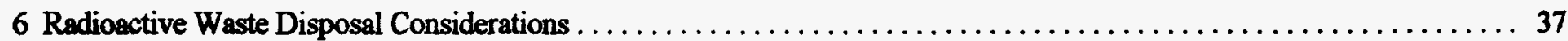

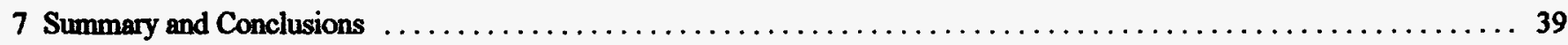

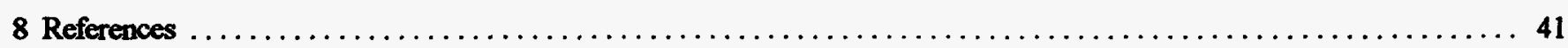

Appendix A: Summary of PNL Radiochemical Procedures for

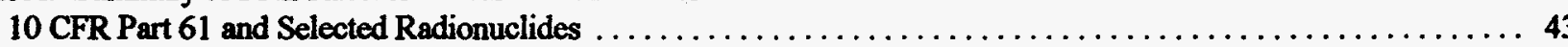




\section{Figures}

2.1 Schematic of BWR Cruciform Control Rod Showing Sampling Locations DER-1, DER-2, and DER-3

2.2 Schematic of PWR Rod Cluster Control Assembly (RCCA) Showing Sampling Locations DER-7, DER-8, DER-9, and DER-10

2.3 Schematic of Burnable Poison Rod Assembly (BPRA) Showing Sampling Locations for DER-4, DER-5, and DER- 6

3.1 Schematic Elevation View of Collimator System for Direct Gamma-Ray Spectromety of Spent Control Rods 10

4.1 Photo of Sample DER-2 from the CRB

4.2 Photo of Sample DER-3 from the CRB

4.3 Photo of Stainless Steel Cladding for Sample RCCA-5 (similar to DER-8) from the RCCA

6.1 Decrease of Concentration with Time for Dominant Isotopes in RCCA 


\section{Tables}

3.1 Curies of 60Co Measured by Two Direct Assay Techniques in Spent Control Rods

4.1 Radionuclide Concentration Observed in Cruciform Control Rod Blade Samples .

4.3 Radionuclide Concentration Observed in Reactor Rod Cluster Control Assembly (RCCA) Samples

4.4 Radionuclide Concentration in Boron Carbide Material from Cruciform Control Rod Blade (CRB) Samples

Radionuclide Concentrations Observed in Borosilicate Glass Specimens from the Burnable Poison Rod Assembly (BPRA) Samples

4.7 Selected Major, Minor, and Trace Elements in Boron Carbide and Borosilicate Glass Samples

4.8 Comparison of Our Data to Reported Data for the Metal Cladding on the Control Rod Assemblies

5.1 Comparison of Radionuclide Contents in Spent Control Rods by Direct Assay and Sampling/Analysis Methods (Inventories in Curies)

5.2 Comparison of Empirical and Calculated Curie Contents for ${ }^{60} \mathrm{Co}$

5.3 Comparison of Empirical and Calculated Curie Contents for ${ }^{59} \mathrm{Ni}$

5.4 Comparison of Empirical and Calculated Curie Contents for ${ }^{63} \mathrm{Ni}$ 


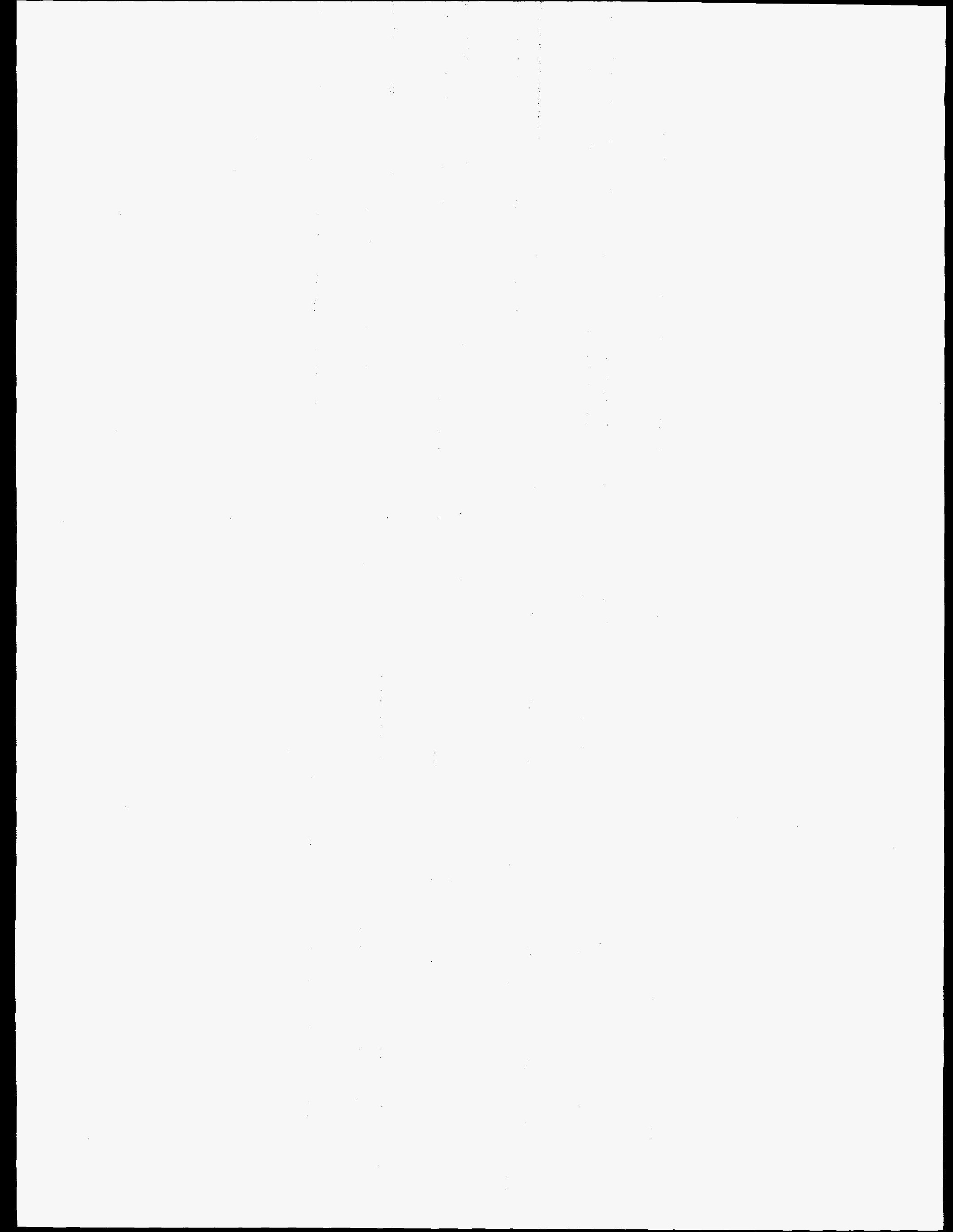




\section{Executive Summary}

This study has been conducted by Pacific Northwest Laboratory (PNL) to provide the U. S. Nuclear Regulatory Commission (NRC) and licensees with a more comprehensive data base and regulatory assessment of the radiological factors associated with the decommissioning of nuclear power stations and the disposal of wastes generated during such activities. This report is the final of a series of NUREG/CR documents which have extended the state of knowledge of the radiological source term conditions existing at nuclear power stations at the initiation of decommissioning operations. Earlier studies addressed the characterization of residual radionuclide contamination deposited throughout nuclear power stations (Abel, et al., 1986; Robertson, et al., 1991; Robertson, et al., 1993). Later work included the detailed analyses of neutronactivated metal waste (e.g., spent fuel assembly hardware and reactor pressure vessel steel) removed from reactor pressure vessels (Robertson, et al., 1991; Robertson, et al., 1993). This report describes the results of non-destructive and laboratory radionuclide measurements, as well as waste classification assessments, of BWR and PWR spent control rod assemblies which are typical of those being shipped to commercial low-level waste disposal facilities. The primary objectives of these characterization studies were: 1) to determine the spectrum of radionuclides produced in various types of spent control rods, 2) assess the accuracy of various direct and indirect methods commonly in use for determining the radionuclide inventories in the control rods, 3) evaluate the waste disposal options for these highly radioactive components, and 4) provide a more comprehensive data base for conducting further decommissioning assessments of nuclear power stations.

During 1992 a unique opportunity became available through the DOE Office of Civilian Waste Programs to obtain samples of spent control rod assemblies for conducting detailed radiological characterization, classification, and assessment of waste disposal options. The radionuclide composition, distributions, and inventories for three types of spent control rod assemblies were determined by both direct assay techniques and by sampling and laboratory radiochemical analyses. These empirical measurements were then compared with the results of calculational methods to determine the accuracy of the calculations.

The three types of spent control rod assemblies, having well-documented irradiation histories, examined in this study included a General Electric BWR Control Rod Blade (CRB) from Duane Arnold Energy Center, a Westinghouse PWR Rod Cluster Control Assembly (RCCA) from Point Beach I Nuclear Station, and a Westinghouse PWR
Burnable Poison Rod Assembly (BPRA) also from Point Beach I Nuclear Station.

The BWR Control Rod Blade, composed of stainless steel cladding tubes with with boron carbide poison, contained predominantly ${ }^{60} \mathrm{Co}$, which was produced by neutron activation of the nominally $2800 \mathrm{ppm}$ of stable cobalt present in the steel. Nickel-63, ${ }^{93 \mathrm{~m}} \mathrm{Nb}$, and ${ }^{59} \mathrm{Ni}$ were the next most abundant long-lived activation products, being about 10-fold, 300-fold, and 1000-fold lower, respectively, in concentration compared to ${ }^{60} \mathrm{Co}$. The ${ }^{94} \mathrm{Nb}$ concentrations averaged about 50 -fold lower than those for ${ }^{93 \mathrm{~m}} \mathrm{Nb}$. The concentrations of the activation products decreased approximately 50-fold from the insert end to the tail end of the neutron-absorbing section of the CRB. The gamma dose rate at the insertion end of the CRB peaked at about $2900 \mathrm{R} / \mathrm{h}$ at contact in August, 1990 approximately two years after removal from service. The boron carbide neutron absorber material in the CRB contained relatively low concentrations of all radionuclides, and this material contributed insignificantly to the total radionuclide inventory for the CRB.

The PWR Rod Control Cluster Assembly, composed of stainless steel-clad borosilicate glass, likewise contained predominantly ${ }^{60} \mathrm{Co}$, produced from the $1600 \mathrm{ppm}$ of cobalt present in the steel. This steel likewise contained similiar amounts of ${ }^{63} \mathrm{Ni},{ }^{93 \mathrm{~m}} \mathrm{Nb},{ }^{59} \mathrm{Ni}$, and ${ }^{94} \mathrm{Nb}$, relative to the ${ }^{60} \mathrm{Co}$, as observed in the CRB. The concentrations of the activation products were rather uniformly distributed over the length of the neutron-absorbing section of the BPRA. The gamma dose rate over this section was about $120 \mathrm{R} / \mathrm{h}$ at contact in August, 1990, approximately 15 years after removal from service.

The PWR Rod Control Cluster Assembly is composed of stainless steel-clad rods of an alloy made of $80 \% \mathrm{Ag}, 15 \%$ In, and $5 \% \mathrm{Cd}$ for absorbing neutrons. The radionuclide composition of this assembly is unique, in that the most abundant long-lived radionuclide was ${ }^{108 \mathrm{~m}} \mathrm{Ag}$. Silver- $108 \mathrm{~m}$ has a half-life of 130 years and decays mainly by electron capture accompanied by the emission of three relatively high energy coincident gamma rays $(439,614$, and 722 $\mathrm{keV}$ ) each of $91 \%$ relative intensity. On a per gram basis, the concentration of ${ }^{108 \mathrm{~m}} \mathrm{Ag}$ in this alloy is comparable to the ${ }^{60} \mathrm{Co}$ concentrations in the stainless steel cladding, but the mass of the $\mathrm{Ag} / \mathrm{In} / \mathrm{Cd}$ alloy greatly exceeds that of the stainless steel cladding. Therefore, the ${ }^{108 m} \mathrm{Ag}$ will be the dominant gamma dose-contributing radionuclide in this type of control rod assembly for many hundreds of years. Silver$108 \mathrm{~m}$ is not addressed in 10CFR61, so it cannot be considered in waste classification assessments for this assembly. The RCCA was fully withdrawn at all times 
during full power operations and only the first few tens of $\mathrm{cm}$ on the insertion end of the RCCA were highly neutron activated. The gamma dose rate at the insertion end peaked at about $290 \mathrm{R} / \mathrm{h}$ at contact in August, 1990, approximately 10 years after removal from service.

It was possible to directly compare radionuclide measurements for several activation products $\left({ }^{60} \mathrm{Co},{ }^{63} \mathrm{Ni}\right.$, ${ }^{59} \mathrm{Ni}$, and ${ }^{94} \mathrm{Nb}$ ) with samples taken from approximately the same locations on the rod assemblies by another group at PNL (Migliori, et al., 1994). The results of this intercomparison were very good, with general agreement being in the range of $1-25 \%$, except for ${ }^{94} \mathrm{Nb}$ where our results averaged about 23 times higher.

Direct assay measurements of the three spent control rod assemblies were conducted in the hot cell facilities at PNL. This technique, which was described in detail in Robertson, et al. (1993), consists of: 1) direct gamma ray spectrometry to identify those radionuclides contributing to the gamma dose rate, 2) thermoluminescent dosimetry (TLD) to measure the gamma dose rate along the length of the control $\mathrm{rod}, 3)$ dose-to-Curie conversion using appropriate shielding/geometry codes, and 4) correlations (scaling) to the ${ }^{60} \mathrm{Co}$ to estimate the concentrations of other 10CFR61 radionuclides in the assemblies. The results of the direct assay measurements were only $10 \%$ lower than the empirical measurements for the CRB and the BPRA. The laboratory value for ${ }^{108 \mathrm{~m}} \mathrm{Ag}$, which was the most abundant radionuclide in the RCCA and contributed to most of the gamma dose, was only $2 \%$ higher than the direct assay results, but the ${ }^{60} \mathrm{Co}$ and ${ }^{110 \mathrm{~m}} \mathrm{Ag}$ laboratory values for the RCCA were a factor of 2.8 higher than the direct assay results. This generally good agreement between the laboratory versus the direct assay measurements of the radionuclide contents of spent control rod assemblies lends confidence that the direct assay methodologies can provide very accurate determinations of the radionuclide inventories of spent control rod assemblies and other types of highly neutron-activated metal wastes.

Calculated radionuclide inventories for these spent control rod assemblies were also determined by a reactor physics group at PNL using both ORIGEN2 and MCNP modeling, and their results were compared with our laboratory measurements. Neutronics modeling calculations are especially difficult to perform for spent control rod assemblies because of the large quantities of neutron absorbing materials in the rods and the uncertainties in their exact position relative to the reactor core over their operational history. The objective of this comparison was to determine how accurate the calculations were relative to the laboratory measurements (assumed to be the more accurate of the two methods). This comparison showed that for the CRB our laboratory values for ${ }^{60} \mathrm{Co},{ }^{63} \mathrm{Ni}$, and ${ }^{59} \mathrm{Ni}$ were about 3 to 5 times higher than the calculated values at the insert ("hot") end of the assembly, and at the "cold" end of the assembly our laboratory values were 0.15 to 0.68 times the calculated values. For the BPRA, our laboratory ${ }^{60} \mathrm{Co}$ values were 3.9 times higher than the calculated values, and the laboratory ${ }^{63} \mathrm{Ni}$ and ${ }^{59} \mathrm{Ni}$ values were 0.78 and 0.73 times the calculated values. For the insert end of the RCCA, our laboratory ${ }^{60} \mathrm{Co}$, ${ }^{63} \mathrm{Ni}$, and ${ }^{59} \mathrm{Ni}$ values were $3.6,12.7$, and 12.6 times higher, respectively, than the calculated values. These comparisons confirm the difficulty in calculating the radionuclide inventories in spent control rod assemblies. It appears that generally it is possible to perform radionuclide inventory calculations that are within a factor of about 5 of the true values, but occasionally, differences exceeding a factor of ten were observed. Obviously, the direct assay techniques are preferable to the calculational methods for estimating radionuclide inventories of spent control rod assemblies.

The radionuclide inventories of the three spent control rod assemblies were assessed to provide a 10CFR6I waste classification of these materials. If concentration averaging over the entire assemblies is performed, as allowed in 10CFR61.55, then each of the assemblies would be classified as Class C low-level waste, even though the "hot" ends of the CRB and BPRA approached or slightly exceeded the Class $\mathrm{C}$ limit. Nickel- 63 , followed by ${ }^{94} \mathrm{Nb}$, were the classification-controlling radionuclides. Since the concentrations of these radionuclides are so close to the Class $\mathrm{C}$ limit for the these types of activated-metal waste it is important that the determination of their radionuclide contents be determined as accurately as possible.

The information and data bases that have been generated during these radionuclide characterization studies have provided a more comprehensive and reliable assessment of the radiological factors associated with the decommissioning of nuclear reactor power stations. 


\section{Foreword}

This document is the final report of a study to provide radiological characterizations, classifications, and assessments in support of the decommissioning of nuclear power stations. This document describes the results of non-destructive and laboratory

radionuclide measurements, as well as waste classification assessments, of BWR and PWR spent control rod assemblies which are typical of those being shipped to commercial low-level waste disposal facilities. The information contained in this report is used by the NRC to help develop rules and guidance relative to radioactive waste disposal and reactor decommissioning.

This report is not a substitute for NRC regulations, and compliance is not required. The approaches and/or methods described in this report does not necessarily constitute NRC approval or agreement with the information cited herein.

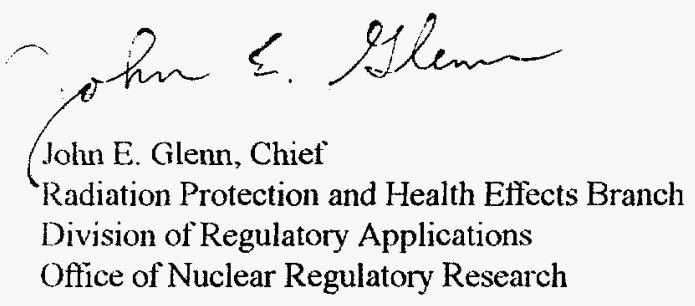




\section{Acknowledgments}

The authors wish to thank the staff of the 324 Building Shielded Hot Cell and the staff of the 325 Building Shielded Hot Cell at PNL for their help in obtaining the samples from each of the spent control rod assemblies. The authors also wish to thank

R. J. Migliore for his help in obtaining physical dimensions of the control rods. The ICPMS analytical work was performed by E. J. Wyse and J. T. Bramson.

In addition, the authors wish to thank Dr. Carl Feldman of the Office of Nuclear Reactor Regulation, U.S. NRC, for his longstanding interest and support of this program which was sponsored by the U.S. Nuclear Regulatory Commission. 


\section{Introduction}

\subsection{Project Plan and Objectives}

The U.S. Nuclear Regulatory Commission (NRC) has enacted rules setting forth technical, safety, and financial criteria for decommissioning of licensed nuclear facilities, including commercial nuclear power stations ( $53 \mathrm{FR}$ 24018-56). These rules have addressed five major issues; decommissioning alternatives, timing, planning, financial assurance, and environmental review. Also, the rules governing disposal of low-level radioactive wastes in commercial shallow land burial facilities will be applicable to most of the wastes generated during reactor decommissioning (10 CFR 61). The appropriate response to each of these issues by the licensee and the NRC depends greatly on an accurate and reliable assessment of the residual radiological conditions existing at the nuclear power stations at the time of decommissioning. Large volumes of data exist which describe the radionuclide concentrations associated with active waste streams generated at nuclear power stations. However, comparatively little information has been available that documents the residual radionuclide concentrations, distributions, and inventories residing in contaminated piping, components, and materials of nuclear power plant systems, and in neutron-activated materials associated with the reactor pressure vessel and biological shield. Especially lacking was a detailed radiological characterization of the numerous types of wastes encountered during an actual reactor decommissioning and a characterization of the highly neutron-activated metal components associated with pressure vessel hardware, spent fuel assembly hardware, and spent control rods and control assemblies.

Pacific Northwest Laboratory (PNL) $)^{1}$ has conducted this study to provide the NRC and licensees with a more comprehensive data base for regulatory assessment of the radiological factors associated with reactor decommissioning and disposal of wastes generated during these activities. This final phase of the study has focused on the radionuclide characterization of dismantled neutronactivated components from commercial power reactors, e.g. spent control rod assemblies from a BWR and a PWR station. This work has addressed the following objectives:

- radiological characterization and classification of intensely radioactive materials removed from the reactor pressure vessel, including spent control rod assemblies from commercial nuclear power plants

'Pacific Northwex Laboratory is operated for the U.S. Department of Energy under Contract DE-AC06-76RLO 1830.
- evaluation of the accuracy of direct assay techniques and computer code calculations for estimating/predicting radionuclide inventories in retired reactors and neutron-activated components

- $\quad$ assessment of waste disposal options associated with reactor decommissioning.

\subsection{Scope of Study}

This final phase of the study has focused on the characterization and classification of in-core reactor components which will be part of the intensely radioactive waste materials derived from nuclear reactor decommissioning. Earlier studies in this work addressed the characterization of residual radionuclide contamination deposited throughout nuclear power stations (Abel, et al., 1986; Robertson, et al., 1991; Robertson, et al., 1993). Later work included the detailed analyses of neutronactivated metal waste (e.g., spent fuel assembly hardware and reactor pressure vessel steel) removed from reactor pressure vessels (Robertson, et al., 1991; Robertson, et al., 1993). This final phase involved non-destructive and laboratory radionuclide measurements, as well as waste classificaton assessments, of one BWR and two PWR spent control rod assemblies which are typical of those being shipped to commercial low-level waste disposal facilities. The scope of these characterization studies involved: 1) determination of the spectrum of radionuclides produced in the three types of control rod assemblies, 2) assessment of the accuracy of various direct and indirect methods commonly in use for determining the radionuclide inventories in the control rods, 3) evaluation of the waste disposal options for these highly radioactive waste components, and 4) providing a more comprehensive database for conducting further decommissioning assessments of nuclear power stations.

\subsection{Waste Disposal Options for Neutron Irradiated Components Associated with Reactor Decommissioning}

The rule governing disposal of low-level radioactive wastes in shallow land burial facilities (10 CFR 61) will have direct impact on the options available for disposal of highly radioactive components of decommissioning wastes. Previous studies by Smith et al. (1978) and Oak et al. (1980) have indicated that all primary, secondary, and auxiliary systems in a nuclear power plant would probably have residual radionuclide contamination levels sufficiently low 
to permit disposal as Class A waste. The Shippingport Station decommissioning provided an excellent opportunity to test and confirm these previous observations (Robertson, et al., 1991).

The waste disposal options for highly radioactive neutronactivated metal components associated with spent fuel assembly hardware from PWR and BWR stations were previously evaluated (Robertson, et al., 1991; Robertson; et al., 1993). It was demonstrated that the ${ }^{59} \mathrm{Ni}$, ${ }^{63} \mathrm{Ni}$, and ${ }^{94} \mathrm{Nb}$ concentrations in these materials classified them in the greater-than-Class $\mathrm{C}$ category.

This present study has provided, for the first time, detailed measurements and classification of the long-lived neutron activation products in a spent BWR control rod blade and in two PWR control rod assemblies. These control rods were sampled and detailed radiochemical analyses of both cladding and neutron absorber materials were performed. The waste classification of these materials was then determined and disposal options considered.

\subsection{Background Information}

During the late 1970s and early 1980s, Pacific Northwest Laboratory conducted a number of studies for the NRC to assess the technology, safety, and costs associated with reactor decommissioning (Smith, et al ., 1978; Oak, et al., 1980; Wittenbrock, 1982; Murphy and Holter, 1982;

Konzek, et al., 1982). These studies were based on extremely limited radionuclide source terms for residual radioactivity within a retired nuclear power plant. To fill this data gap, the NRC sponsored two research projects to provide a detailed database describing the residual radionuclide concentrations, distributions, and inventories within retired nuclear power stations (Abel, et al., 1986; Robertson, et al., 1984; Evans, et al., 1984; Evans, et al., 1988). These projects characterized the neutron activation products formed in reactor pressure vessels and their internal components, and the residual surface contamination spread to all other systems and areas of the station. Although these studies greatly strengthened the radionuclide source term information on residual radioactivity in nuclear power stations, several major data gaps were further identified. These consisted of a lack of detailed radiological characterization data during an actual reactor decommissioning and a lack of radionuclide contents of neutron activated metal components from within reactor pressure vessels.

This program has conducted research to address these important areas of reactor decommissioning. The Shippingport Station decommissioning provided a detailed radiological characterization during the dismantlement and decommissioning of a nuclear power station (Robertson, et al., 1991, Robertson, et al., 1993). In addition, specimens of spent fuel assembly hardware and pressure vessel components were analyzed to determine their radionuclide contents for waste disposal considerations.

This present report discusses the results of detailed radiological characterization of spent control rod assemblies. The spent control rod assemblies were analyzed to determine radionuclide contents, waste classification, disposal options, and the degree of accuracy of calculational methodology for predicting the concentrations of neutron-activated products in irradiated metal components. The results of this source term characterization work will provide for more accurate and reliable assessments of the technology, safety, and costs of reactor decommissioning. 


\section{Description of Spent Control Rod Assemblies}

A wide variety of neutron-activated metal wastes, including spent control rods and assemblies, are being generated in increasing quantities at both operating and decommissioned nuclear power stations throughout the world. These wastes, which originate from within the reactor pressure vessel, have normally been exposed to very high neutron fluences and subsequently have extremely high dose rates (thousands of $\mathrm{R} / \mathrm{h}$ ). Before disposal, the radionuclide contents of these wastes must be measured to determine the waste classification, packaging requirements, and shipping regulations. The very high dose rates associated with these components greatly complicate the sampling and radionuclide analyses that must be performed. Usually activation modeling calculations or remote, direct assay techniques have been employed to determine the Curie contents of these wastes (Cline, et al., 1987). The reliability and accuracy of these calculational and direct assay methods need to be further demonstrated. This verification can only be accomplished by careful sampling and laboratory analysis of the radionuclides of interest and their stable parent elements in the waste metal components, and by comparing these measurements with the results of the calculations and direct assays performed on the same activated metal waste components.

\subsection{Description of Spent Control Rods}

Three types of spent control rod assemblies with welldocumented irradiation histories (see Migliore, et al., 1994) have been made available for sampling and radiological characterization at PNL through the U.S. Department of Energy's Office of Civilian Radioactive Waste Management. These components are also being utilized in this NRC project to compare and assess the three main methods of characterizing the radionuclide contents of highly neutronactivated metal wastes: 1) sampling and laboratory analyses, 2) direct assays, and, 3) calculational methods. In addition, these measurements will provide important information concerning waste classification and disposal requirements. The three different types of spent control rods examined in this study are listed in Table 2.1, and include a BWR Control Rod Blade (CRB), a PWR Rod Cluster Control Assembly (RCCA), and a PWR Burnable Poison Rod Assembly (BPRA).

\subsubsection{Description of BWR Control Rod Blade (CRB)}

The CRB was obtained from a General Electric BWR station operated by Iowa Light and Power Company at the Duane Arnold Energy Center. The CRB is predominantly stainless steel, and inside each blade are stainless steel tubes that are filled with boron carbide $\left(\mathrm{B}_{4} \mathrm{C}\right)$ powder which acts as a neutron absorbing material. The absorbing section of the blade is cruciform shaped. At the bottom of the blade is a circular velocity limiter and the overall length is about 14 feet. Figure 2.1 is a schematic representation of the BWR CRB, showing the sampling locations, DER-1, DER-2, and DER-3. Details of the sampling are given in Section 4.

The irradiation history of this control rod is described by Migliore, et al., (1994). This CRB was exposed to 10 operating cycles and discharged in October 1988. It was inserted to various levels in the core during its exposure, but the exposure of the blade during full power was very low since the reactor would be either coasting down or at zero

Table 2.1 Spent Control Rod Assemblies for Radiological Characterization

\begin{tabular}{|c|c|c|c|}
\hline Assembly Type & $\begin{array}{l}\text { Discharge } \\
\text { Date }\end{array}$ & Reactor Station & Materials Sampled \\
\hline $\begin{array}{l}\text { BWR Control Rod Blade } \\
\text { (CRB) ID No. AR-0054R }\end{array}$ & $10 / 88$ & Duane Arnold Energy Center ${ }^{\circ}$ & Stainless steel, $\mathrm{B}_{4} \mathrm{C}$ \\
\hline $\begin{array}{l}\text { PWR Rod Cluster Control } \\
\text { Assembly (RCCA) } \\
\text { ID No. R03 }\end{array}$ & $4 / 85$ & Point Beach I Nuclear Station & Stainless steel, $\mathrm{Ag} / \mathrm{Cd} / \mathrm{In}$ alloy \\
\hline $\begin{array}{l}\text { PWR Burnable Poison } \\
\text { Rod Assembly (BPRA) } \\
\text { ID No. 4P5 }\end{array}$ & $11 / 75$ & Point Beach 1 Nuclear Station & Stainless steel, B glass \\
\hline
\end{tabular}


Description of Assemblies

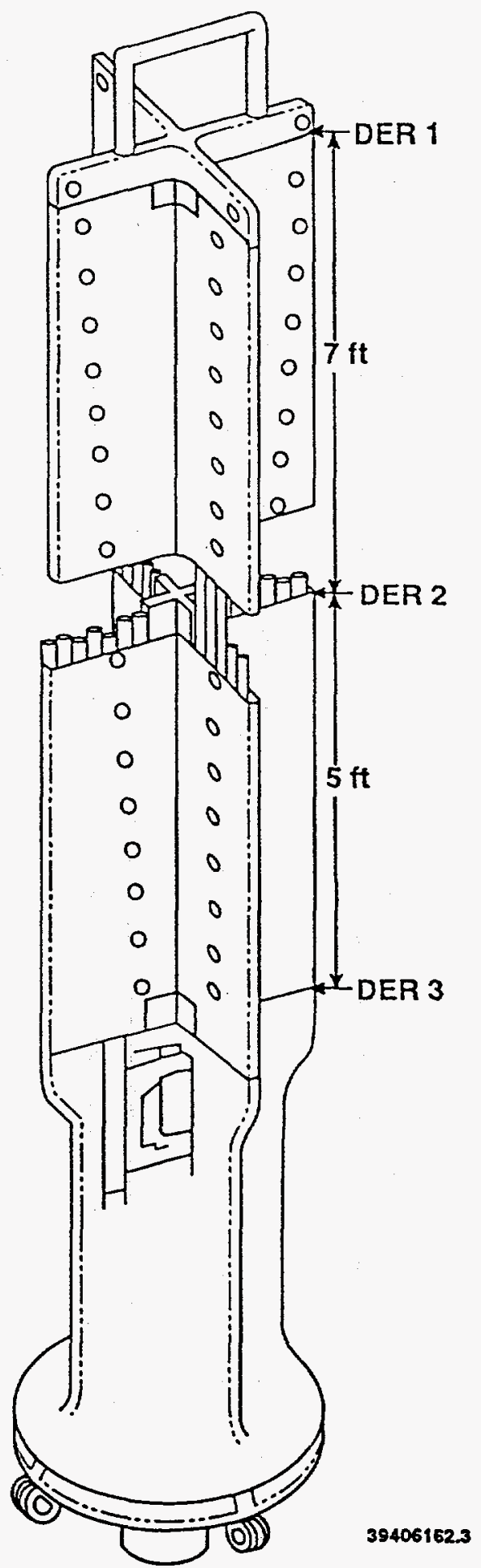

Figure 2.1 Schematic of BWR Cruciform Control Rod Showing Sampling Locations DER-1, DER-2, and DER-3. 
power level when it was fully inserted. A measure of the exposure of the CRB is given in Table 2.2 where absorber depletion is tabulated.

The stellite (high Co alloy) bearing section of the control rod was removed at the power station because of the extremely high dose rate due to ${ }^{60} \mathrm{Co}$ in this component. The material sampled and analyzed included the stainlesssteel cladding, as well as the stainless-steel tubes that contained the boron carbide material that acts as a neutron absorber.

Table 2.2 Depletion of Boron-10 in Control Rod Blade*

\begin{tabular}{|c|c|c|}
\hline Quarter & Snvts** & $\%$ Depletion \\
\hline 1 (top) & 1.85 & 30.73 \\
\hline 2 & 1.91 & 31.69 \\
\hline 3 & 1.46 & 21.16 \\
\hline 4 (bottom) & 0.48 & 7.98 \\
\hline
\end{tabular}

\subsubsection{Description of Rod Cluster Control Assembly (RCCA)}

The RCCA was obtained from a Westinghouse designed PWR operated by Wisconsin Electric at Point Beach 1 Nuclear Station. The RCCA is constructed from stainless steel and is approximately 14 feet long. There are 16 rods that are attached to the top of the assembly. Figure 2.2 is a schematic of a PWR RCCA showing sampling locations DER-7, DER-8, DER-9, and DER-10. The RCCA is of special interest, not only because of the stainless-steel cladding, but because of the solid rod of silver-indiumcadmium alloy $(80 \% \mathrm{Ag}, 15 \% \mathrm{In}$, and $5 \% \mathrm{Cd}$ ) used as a neutron absorber. The silver and cadmium can both produce long-lived neutron activation products $\left({ }^{108 \mathrm{~m}} \mathrm{Ag}\right.$ and ${ }^{113 \mathrm{~m}} \mathrm{Cd}$ ) that may be of significance from a wastemanagement perspective. The RCCA was designed to fit into a $14 \times 14$ fuel lattice.

The RCCA was exposed to 12 operating cycles and 102,767 hours of critical reactor service. It was discharged in April 1985. Migliore, et al. (1994) indicate that the RCCA was fully withdrawn at all times during full power operations. The reactor had an output of $1500 \mathrm{MWt}$ and the assembly burnup was $125,589 \mathrm{Mwd} / \mathrm{MTU}$.

\subsection{3 \\ Description of Burnable Poison Rod Assembly (BPRA)}

The BPRA was also obtained from the Point Beach 1 Nuclear Station. This is a PWR control rod assembly designed by Westinghouse. It also is about 14 feet long and constructed primarily from stainless steel. The top of the assembly includes the hold-down bar and spring. Attached to the hold-down assembly are four burnable poison rods and 12 thimble plugs. The thimble plugs are constructed of solid stainless steel while the poison rods are filled with borosilicate glass for neutron absorption. Figure 2.3 is a schematic of the BPRA. The BPRA is of interest because of the stainless-steel cladding, the solid stainless-steel thimble plugs, and the four burnable poison rods which contain cylindrical tubes of borosilicate glass to act as a burnable neutron absorber.

The exposure history of the BPRA is detailed by Migliore, et al. (1994). It was irradiated during Cycle 3 in position E22 and discharged November 16, 1975. 
Description of Assemblies

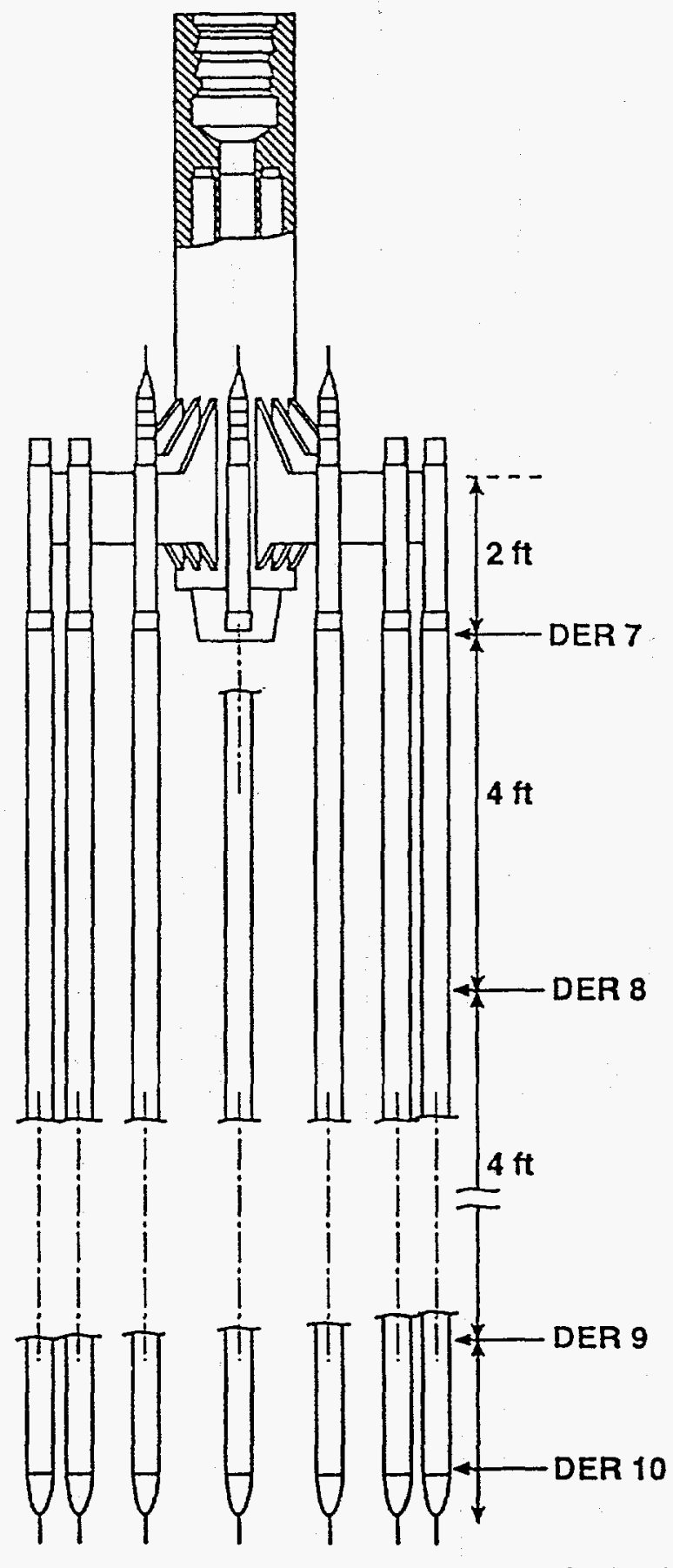

Figure 2.2 Schematic of PWR Rod Cluster Control Assembly (RCCA) Showing Sampling Locations DER-7, DER-8, DER-9, and DER-10. 
Description of Assemblies

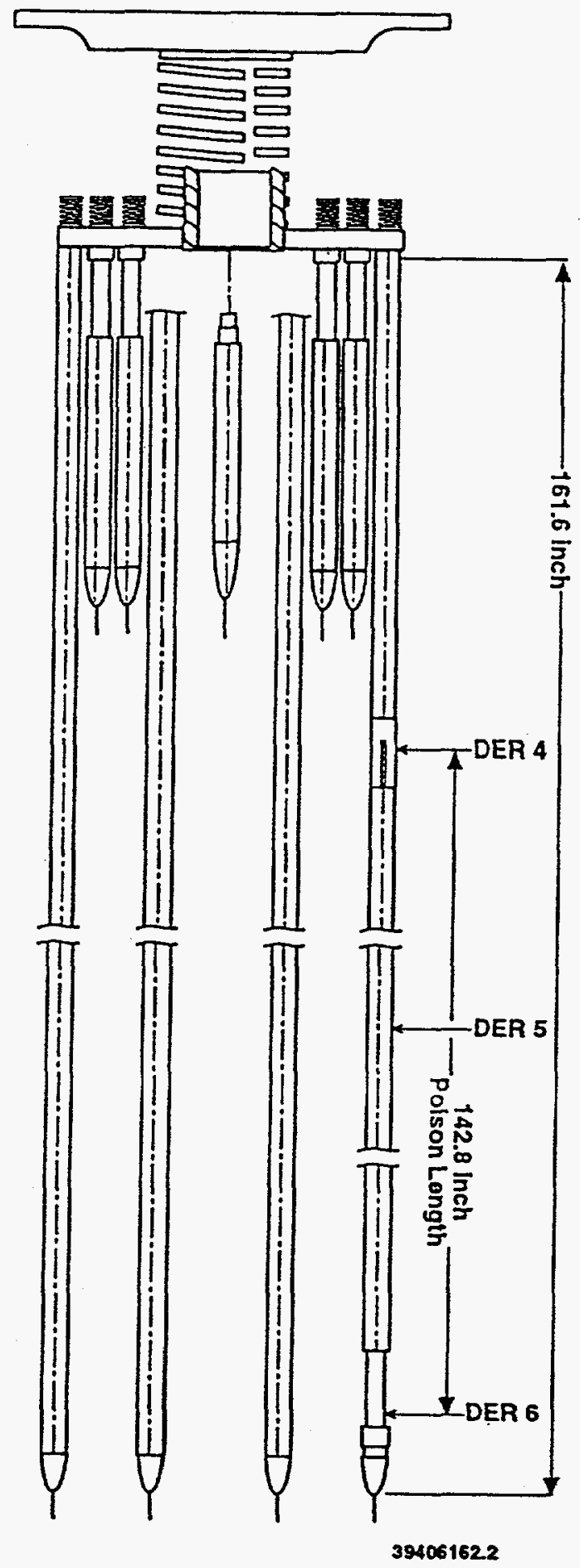

Figure 2.3 Schematic of Burnable Poison Rod Assembly (BPRA) Showing Sampling Locations for DER-4, DER-5, and DER-6 



\section{Description of Direct-Assay Methods to Determine Curie Content}

Two direct-assay methods have been employed to determine the Curie contents of the neutron-activated metal components of the spent control rod assemblies. The directassay techniques are powerful tools that can be used to determine the radionuclides specified in $10 \mathrm{CFR} 61$ for activated metal wastes, especially high-activity components such as spent control rods because of their very high dose rates (thousands of $R / h$ ). Various adaptations of the doseto-Curie conversion technique are used by the nuclear utilities and vendors, in which measured dose rates are converted into radionuclide inventories using shielding/geometry codes and correlation analyses.

\subsection{Gamma Spectrometry and Dose- to-Curie Conversions}

The first method to be described employs gamma spectrometry and dose-to-Curie conversion codes to determine the Curie content of the control rods. The technique involves the following steps: 1) gamma-ray spectrometry for qualitative analysis; 2) thermoluminescent dosimetry (TLD), followed by accurate dose-to-Curie conversion using appropriate shielding codes; and 3) correlation analysis for estimating the concentrations of non-gamma-emitting isotopes. This methodology is described in detail by Robertson, et al. (1993).

The gamma spectrometry for qualitative analysis was performed on the control rods in the 324 Building Hot Cell. Figure 3.1 is a schematic of the setup used to scan the control rods. A $1.3 \mathrm{~cm}$ diameter steel collimator tube was installed through the $1.5 \mathrm{~m}$ thick concrete wall of the hot cell. A portable intrinsic germanium gamma-ray detector was positioned at the outside end of the collimator, and the control rods were hoisted vertically past the inside end of the collimator to provide a vertical profile of the gamma-ray spectra along the length of each of the control rods. In the case of the BWR control rod, it was located almost $6 \mathrm{~m}$ away from the detector when the profile scans were obtained. For the BWR Control Rod Blade and the PWR Burnable Poison Rod Assembly, ${ }^{\circ 0} \mathrm{Co}$ was the predominant radionuclide contributing to the gamma-ray spectra, with a trace of ${ }^{54} \mathrm{Mn}$ also being present. For the PWR Rod Cluster Control Assembly, the predominant radionuclides in the gamma-ray spectrum were ${ }^{100 \mathrm{~m}} \mathrm{Ag},{ }^{110 \mathrm{~m}} \mathrm{Ag}$, and ${ }^{60} \mathrm{Co}$, in that order.

Next, dose-rate profiles were obtained by placing a string of TLD's along the length of each control rod for a short period of time (typically 10 to $30 \mathrm{~min}$ ). The TLD's were then retrieved and read. The gamma-dose-rate information along with the gamma spectrometry data were then used as input to the shielding codes (for example, MCNP - Monte Carlo Neutron and Photon transport code) to convert the dose rates into Curie contents. Once this information had been obtained for the dominant gamma-ray emitting radionuclides, the balance of the radionuclides specified in 10 CFR 61 were calculated using correlation analysis (Robertson, et al., 1993).

The computed activity content of ${ }^{60} \mathrm{Co}$ for the BWR Control Rod Blade as a function of TLD sample location is shown in Figure 3.2. A total Curie content for ${ }^{60} \mathrm{Co}$ was calculated to be $271 \mathrm{Ci}$ (on August 17, 1990).

\subsection{Integral Dose Method}

A second method, called the Integral Dose Method, was also used to determine the Curie content of the spent control rod assemblies. The measured dose rate at each TLD location along the length of the control rod is summed to give a total integrated dose for the entire control rod. The integrated dose is then converted to ${ }^{60} \mathrm{Co}$ content by applying standard dose-to-Curie conversion factors. The gamma spectrum is also used to determine the major gamma-emitting radionuclides present that would be contributing to the dose observed by the TLD's. This information is then input into an activity code that calculates the ${ }^{60} \mathrm{Co}$ concentration at the time of removal from the reactor and then calculates the Curie concentrations of the 10CFR 61 radionuclides at any date specified. Using this method, a total ${ }^{\circ 0} \mathrm{Co}$ Curie content of $282 \mathrm{Ci}$ was measured for the CRB.

\subsection{Results of the Two Direct Assay Methods}

The results of the two direct assay methods are listed in Table 3.1. Excellent agreement was obtained for the PWR Rod Cluster Control Assembly (RCCA) between the MCNP method and the Integral Dose method. In fact, there was only a $1.0 \%$ difference between the Curie contents calculated by the two methods. The agreement between the two techniques was still quite good for the BWR Control Rod Blade (CRB). There was only a $3.9 \%$ difference between the two techniques. The largest disagreement was obtained for the PWR Burnable Poison Rod Assembly (BPRA) at $12.6 \%$ difference between the MCNP results and the Integral Dose method results. 


\section{Description of Methods}

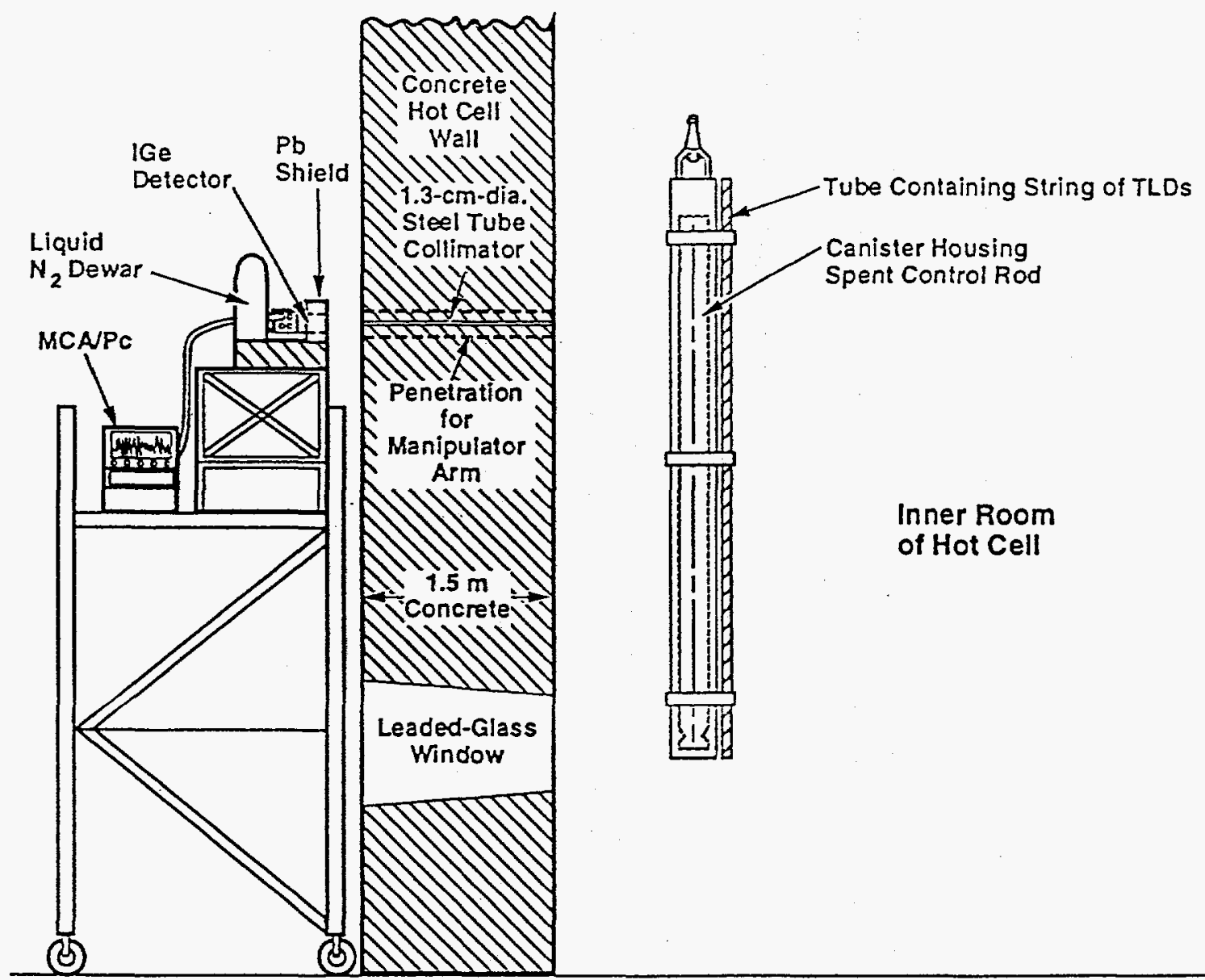

39104063.1

Figure 3.1 Schematic Elevation View of Collimator System for Direct Gamma-Ray Spectrometry of Spent Control Rods 


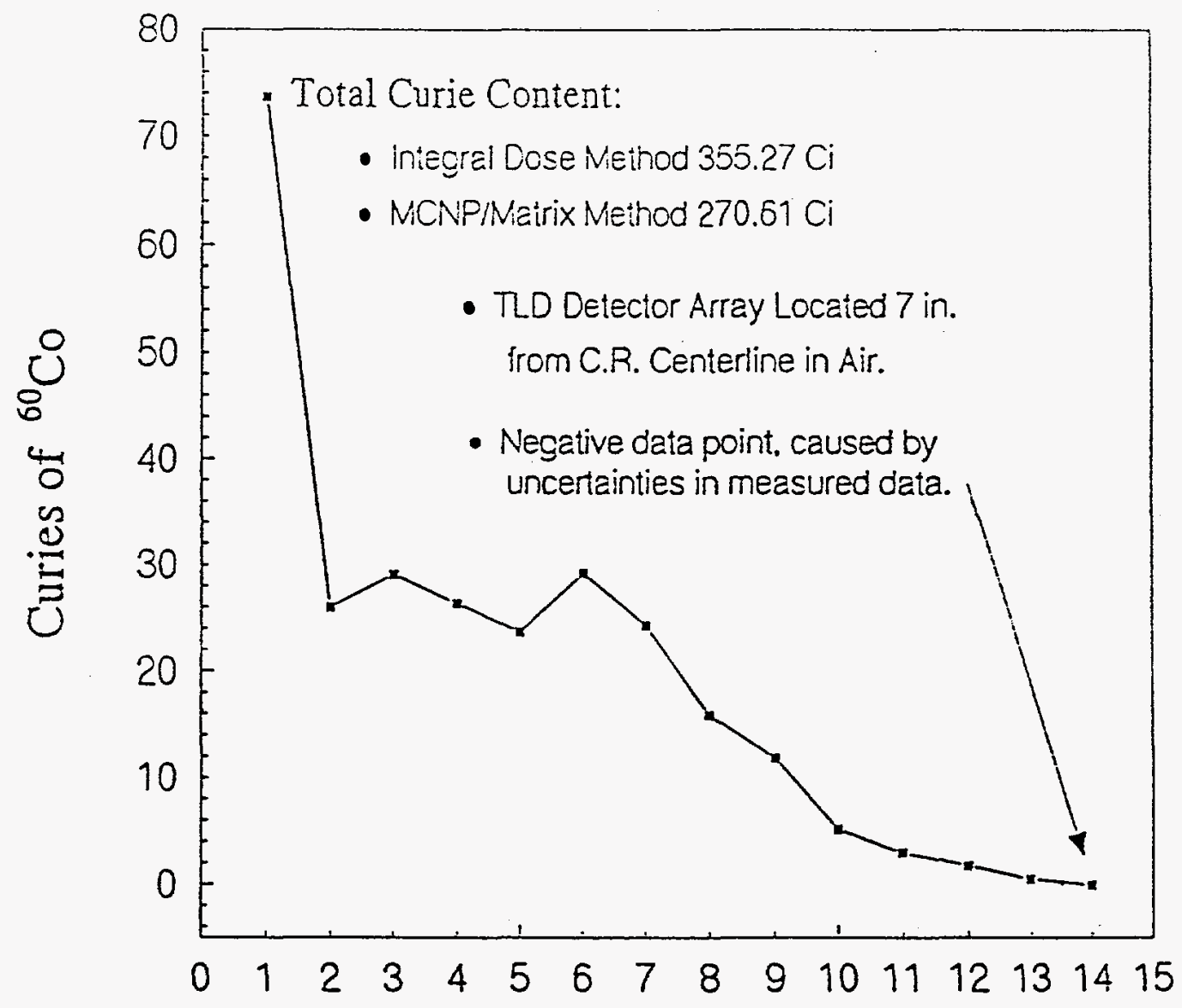

Figure 3.2 Cobalt-60 Distribution and Content of CRB (August 17, 1990). 
Description of Methods

Table 3.1 Curies of ${ }^{60} \mathrm{Co}$ Measured by Two Direct Assay Techniques in Spent Control Rods*

\begin{tabular}{lccc}
\hline Control rod & MCNP method & Integral dose & \% difference \\
\hline BWR Control Rod Blade & 271 & 282 & 3.9 \\
PWR Burnable Poison Rod Assembly & 32.6 & 37.3 & 12.6 \\
PWR Rod Cluster Control Assembly & $19.6^{* *}$ & $19.8^{* *}$ & 1.0 \\
\hline
\end{tabular}

- Activity as of $8 / 20 / 90$

** Includes $3.4 \mathrm{Ci}{ }^{\circ 0} \mathrm{Co}, 9.6 \mathrm{Ci}$ of ${ }^{1000} \mathrm{Ag}, 6.7 \mathrm{Ci}$ of ${ }^{1100} \mathrm{Ag}$ 


\section{Radiological and Stable Element Characterization of Control Rod Samples}

\subsection{Description of Samples Obtained for Radiochemical Analysis}

Actual samples of each control rod were obtained by cutting small specimens from the control rod using remote handling equipment. This work was done in the 324 Building Hot Cells because of the high dose rates associated with these control rods. For this project, typically three samples were obtained from each control rod, one at each end and one from the middle. This sampling has been described in more detail by Migliore, et al. (1994). Using the schematic of each control rod and knowing our sample number (Figures $2.1,2.2$, and 2.3), the corresponding sample obtained by Migliore, et al., may be determined.

Figure 2.1 shows the physical locations for the samples obtained from the BWR Cruciform Control Rod Blade. Each of the three samples consisted of four to six stainlesssteel tubes that were surrounded by the stainless-steel cladding of the cruciform control rod blade. The stainless steel tube samples were labeled " $a$ " through " $f$ " where up to six of the tubes were recovered from a blade, and the outside steel cladding over the tubes was labeled " $\mathrm{z}$ " cladding. Each stainless-steel tube contained compacted boron-carbide powder that served as a neutron poison. Figures 4.1 and 4.2 are pictures of the gross samples obtained for DER-2 and DER-3, respectively. Note the Ushaped stainless steel cladding that held the stainless steel tubes.

Figure 2.2 shows the sampling locations for the RCCA. In addition to the three samples DER-7, -8 , and -9 , an additional sample labeled DER-10, which was located at the most radioactive end of the rod, was obtained. These samples consisted of the stainless-steel cladding (Figure 4.3) and the solid Ag-In-Cd alloy rod (Figure 4.4). A sample of the stainless steel plug (Figure 4.5) on the end of the rod (labeled RCCA-8, right next to DER-10) was also obtained for radiochemical analysis.

Figure 2.3 shows the sampling locations for the three samples obtained from the BPRA. The samples consisted of an outer stainless-steel tube (cladding) and an inner stainless steel tube (cladding) with a cylindrical tube of borosilicate glass between the two metal layers. These samples were labeled DER-4, DER-5, and DER-6.

\subsection{Description of Sample Preparation for Radiochemical and Stable Element Analysis}

The activated metal samples were then transferred to the 325 Building Hot Cell where the individual specimens were separated into their components as much as possible. That is, for the CRB samples, the boron carbide was separated from the individual tubes. Because of the sample handling and looseness of the boron carbide powder, it was not possible to maintain the identity of the boron carbide relative to the tube that it came from. The boron carbide was collected into one composite aliquot for each sample. The stainless steel tubes were separated from the stainless steel cladding that provided the framework for the CRB. Each tube was identified with a letter designation which increased moving from the interior of the CRB to the outer edge of the blade. A small aliquot of the cladding was also obtained for analysis. For the RCCA, the stainless steel cladding was separated from the inner $\mathrm{Ag}-\mathrm{In}-\mathrm{Cd}$ rod in the 325 Building Hot Cells.

The specimens were partially decontaminated at this point by repeated acid etching and then transferred to the 329 Building for final decontamination and/or additional subsampling. The specimens from the CRB consisted of the stainless steel cladding, stainless steel cylindrical tubes, and the boron carbide powder. The specimens for the RCCA consisted of the stainless steel cladding and the solid rod of Ag-In-Cd alloy. The BPRA specimens required additional preparation in the 329 building. The cylindrical tube of borosilicate glass was separated from the inner and outer stainless-steel tubes.

The metal samples were further cleaned by repeated acid rinsing. First, the sample surfaces were cleaned to remove any fission product and activation product debris from their handling in the hot cells. This was determined by monitoring the activity of ${ }^{137} \mathrm{Cs}$ for each acid rinse solution. Once it was determined that the surfaces of the metal specimens had been completely decontaminated from hotcell debris (by the absence of ${ }^{137} \mathrm{Cs}$ in the rinse solutions), a known amount of each metal specimen was dissolved in acid. Liquid aliquots of the parent solution were then taken for analysis by gamma-spectrometry, stable element analysis by ICPMS, and analysis of non-gamma-emitting radionuclides by radiochemical separation techniques. 


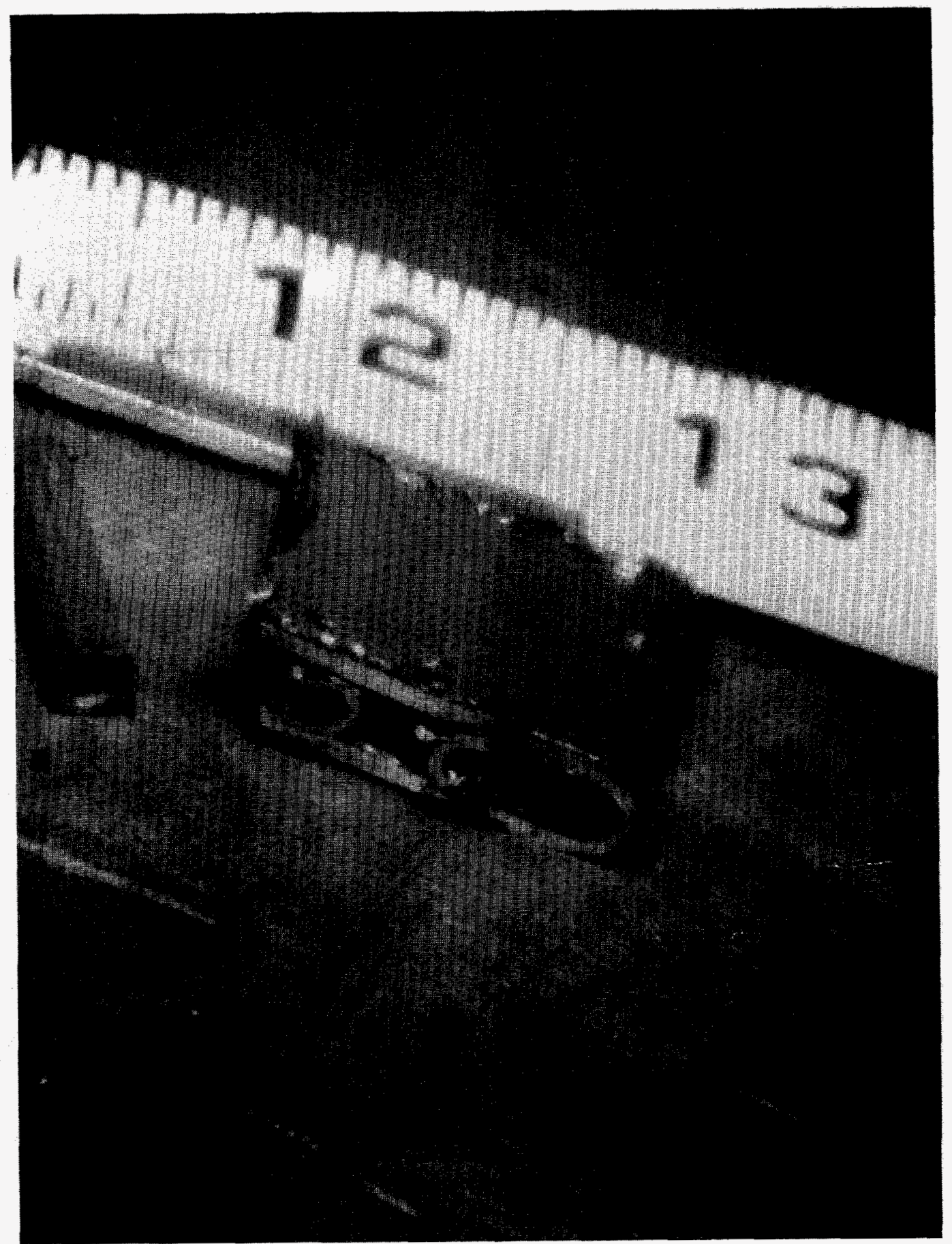

Figure 4.1 Photo of Sample DER-2 from the CRB 


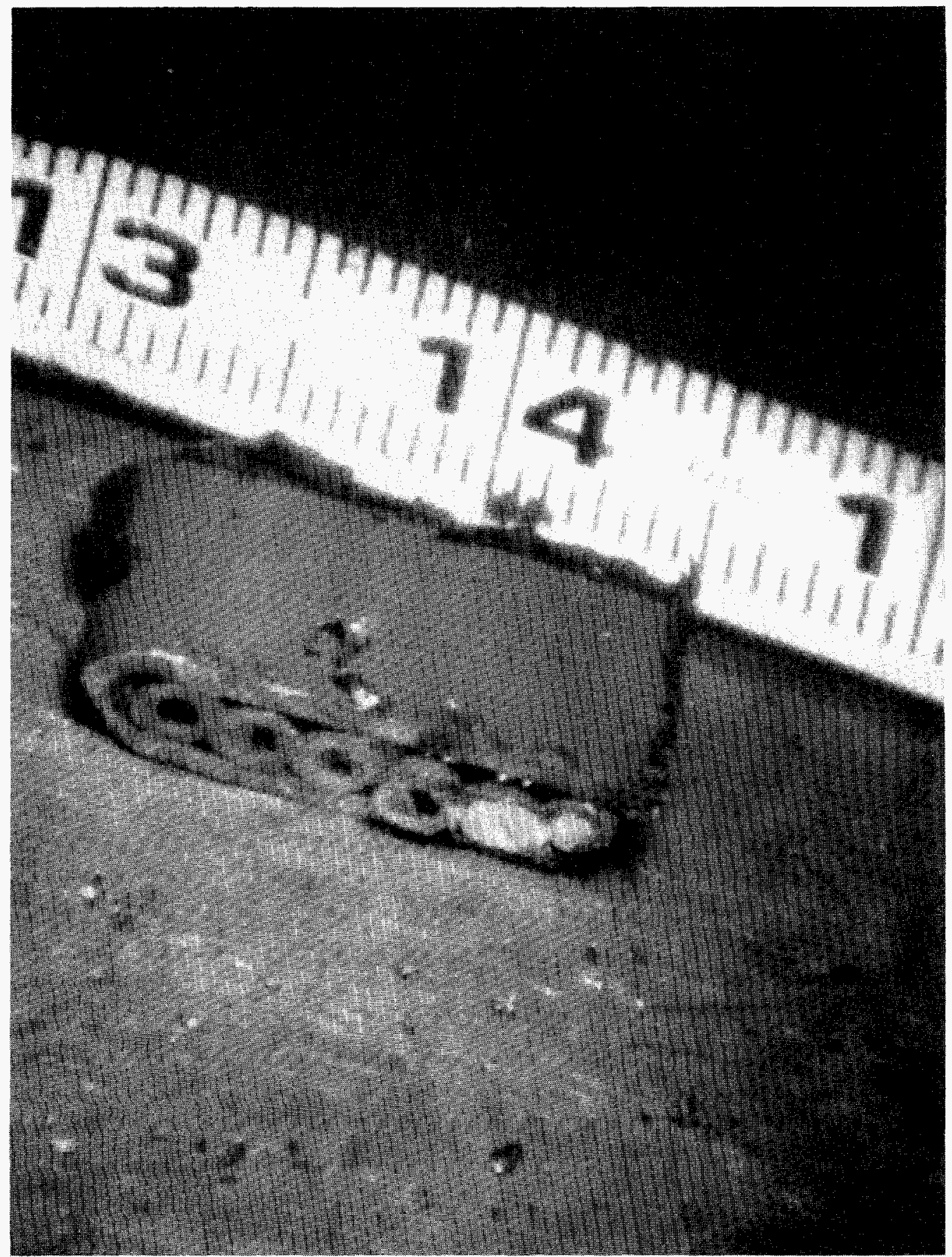

Figure 4.2 Photo of Sample DER-3 from the CRB. 
Element Characterization

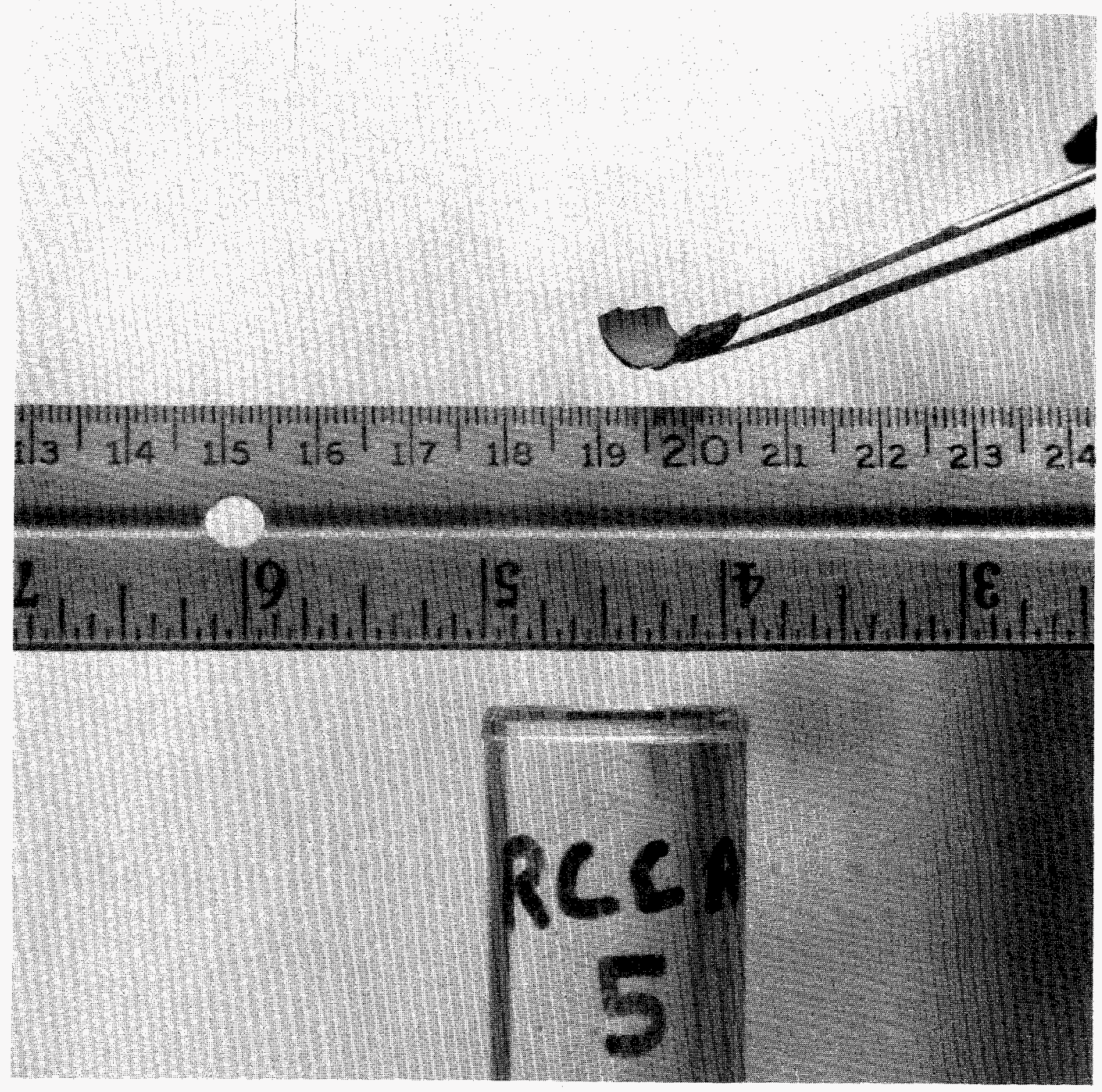

Figure 4.3 Photo of Stainless Steel Cladding for Sample RCCA-5 (similar to DER-8) from the RCCA. 
Element Characterization

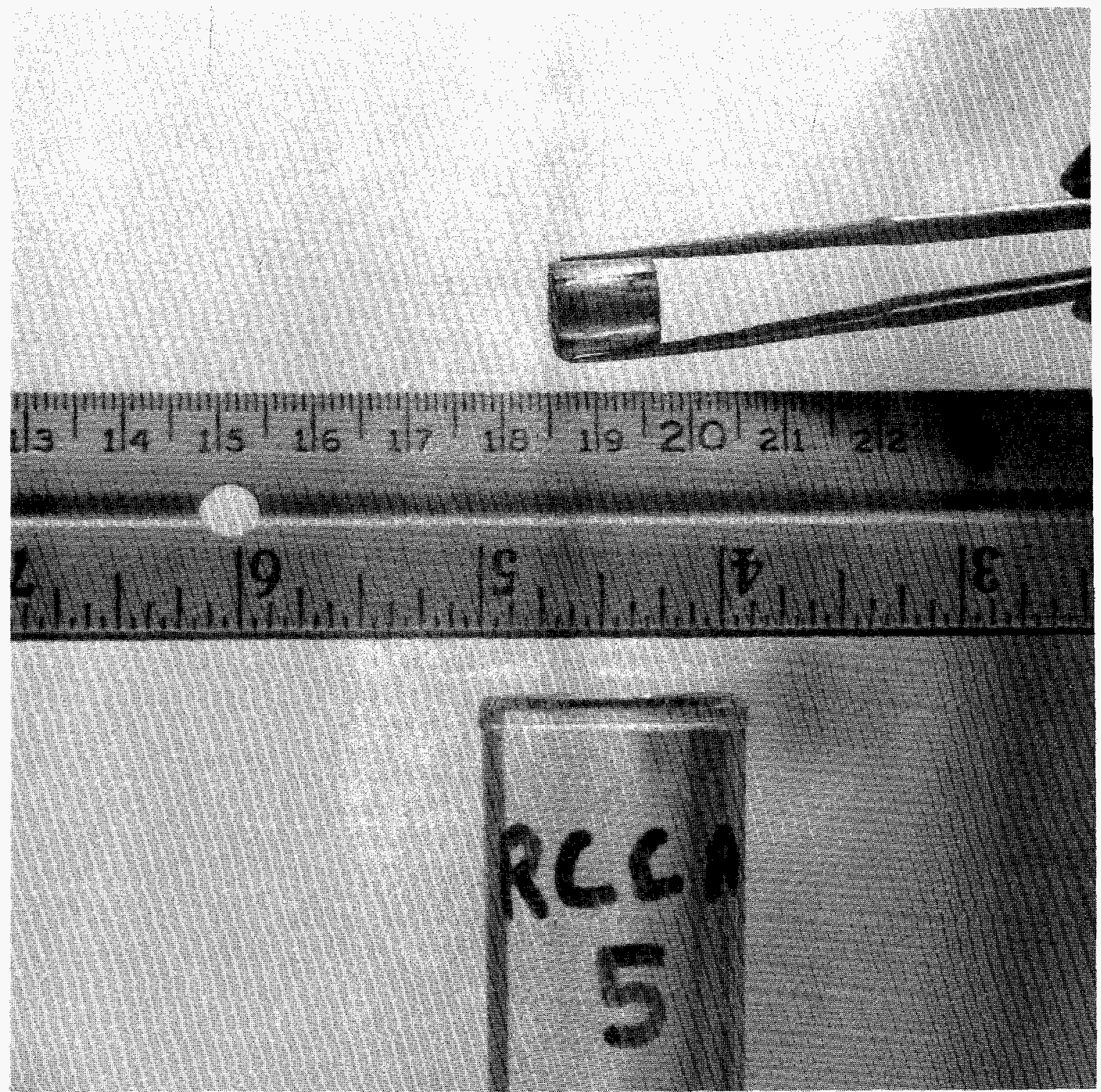

Figure 4.4 Photo of Ag-In-Cd Rod taken from Sample RCCA-5 (similar to DER-8) from the RCCA. 


\section{Element Characterization}

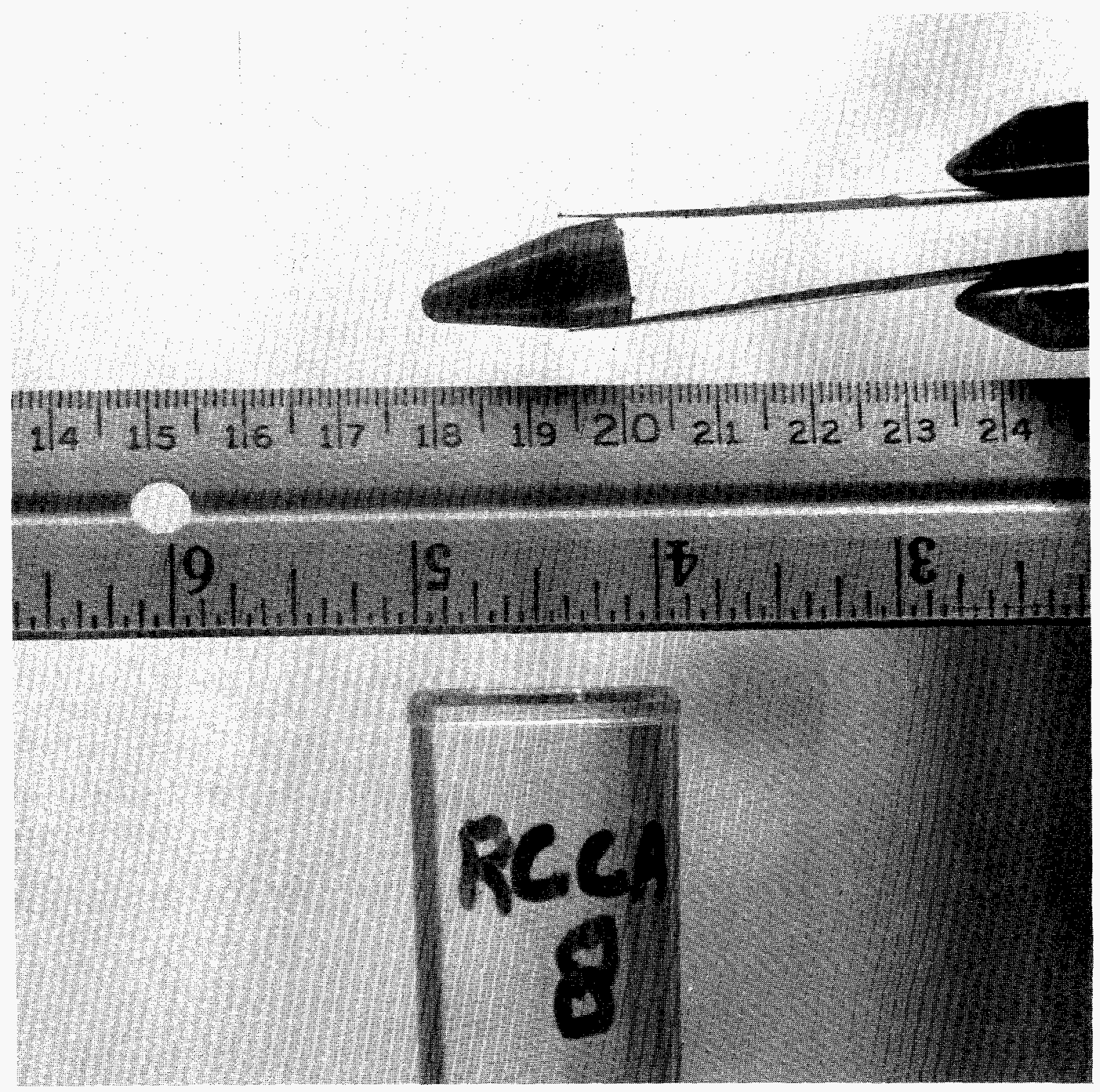

Figure 4.5 Photo of Stainless Steel End Cap for Sample RCCA-8. 


\subsection{Instrumental and Radiochemical Analysis}

Instrumental and radiochemical analyses were performed on the various samples obtained from the three control rods.

\subsubsection{Analysis of Metal Samples from the Control Rods}

The instrumental gamma spectrometric analysis was performed by obtaining known aliquots of the dissolved solutions from each metal sample and diluting it to $10 \mathrm{~mL}$ in a plastic scintillation vial. The radionuclide contents of these sample aliquots were then measured by gamma-ray spectrometry following the procedure described in Lepel (1990). A lithium-drifted germanium detector (14.3\% efficient, $76 \mathrm{cc}$ volume, $1.9 \mathrm{keV}$ FWHM for the $1332.5 \mathrm{keV}$ line of ${ }^{60} \mathrm{Co}$ ) that was coupled to a Nuclear Data multichannel analyzer was used for these analysis. The spectra were then transferred to a DEC PDP $11 / 44$ computer for data analysis using the RAYGUN code (Hensley, et al., 1988) and storage on magnetic media. The following isotopes were measured in the metals: ${ }^{54} \mathrm{Mn}$ and ${ }^{60} \mathrm{Co}$, plus ${ }^{108 \mathrm{~m}} \mathrm{Ag},{ }^{10 \mathrm{~m}} \mathrm{Ag},{ }^{152} \mathrm{Eu},{ }^{154} \mathrm{Eu}$, and ${ }^{155} \mathrm{Eu}$ in the Ag-InCd rods.

Radiochemical separation methods were used to measure ${ }^{59} \mathrm{Ni},{ }^{63} \mathrm{Ni},{ }^{93 \mathrm{~m}} \mathrm{Nb},{ }^{94} \mathrm{Nb}$, and ${ }^{93} \mathrm{Mo}$ in the metal specimens, as well as ${ }^{109} \mathrm{Cd}$ and ${ }^{113 \mathrm{~m}} \mathrm{Cd}$ in the $\mathrm{Ag}$-In-Cd rods. These radiochemical procedures are described in Appendix $\mathrm{A}$.

\subsubsection{Analysis of the Borosilicate Glass from the BPRA}

The following radionuclides were measured in the borosilicate glass by instrumental gamma-ray spectrometry: ${ }^{22} \mathrm{Na},{ }^{26} \mathrm{Al},{ }^{60} \mathrm{Co},{ }^{125} \mathrm{Sb},{ }^{134} \mathrm{Cs},{ }^{137} \mathrm{Cs},{ }^{152} \mathrm{Eu},{ }^{154} \mathrm{Eu}$, and ${ }^{155} \mathrm{Eu}$. The ${ }^{26} \mathrm{Al}$ and ${ }^{22} \mathrm{Na}$ were each determined using a triplecoincidence scheme. The ${ }^{26} \mathrm{Al}$ required the coincident detection of two 511 gamma rays and the $1809 \mathrm{keV}$ line, and the ${ }^{22} \mathrm{Na}$ required the detection of two 511 gamma rays and the $1274 \mathrm{kev}$ line.

Radiochemical separations were performed for ${ }^{238} \mathrm{Pu}$, ${ }^{239 / 240} \mathrm{Pu},{ }^{241} \mathrm{Pu},{ }^{241} \mathrm{Am}$, and ${ }^{244} \mathrm{Cm}$ in the borosilicate glass. These procedures are described in Appendix A.

\subsubsection{Analysis of the Boron Carbide from the CRB}

The following isotopes were measured in the boron carbide by instrumental gamma-ray spectrometry: ${ }^{22} \mathrm{Na},{ }^{26} \mathrm{Al},{ }^{60} \mathrm{Co}$, ${ }^{137} \mathrm{Cs}$, ${ }^{152} \mathrm{Eu}$, ${ }^{154} \mathrm{Eu}$, and ${ }^{155} \mathrm{Eu}$. The ${ }^{22} \mathrm{Na}$ and the ${ }^{26} \mathrm{Al}$ were measured using the triple-coincidence system described above for the borosilicate glass. Radiochemical separations were performed for ${ }^{94} \mathrm{Nb},{ }^{238} \mathrm{Pu},{ }^{239 / 240} \mathrm{Pu},{ }^{241} \mathrm{Pu},{ }^{241} \mathrm{Am}$, and ${ }^{244} \mathrm{Cm}$ in the boron carbide. These procedures are described in Appendix A.

\subsection{Radioanalytical Results from Three Spent Control Rods}

The radiochemical concentration data determined in the metal samples from the three control rods are listed in Tables 4.1, 4.2 and 4.3. Tables 4.4 and 4.5 list the radiochemical data observed in the boron carbide from the $\mathrm{CRB}$ and the borosilicate glass from the BPRA. All the data have been decay corrected to June 1, 1993

The following $10 \mathrm{CFR} 61$ radionuclides were determined in the Type 304 stainless steel metal samples from the CRB: ${ }^{59} \mathrm{Ni},{ }^{63} \mathrm{Ni},{ }^{60} \mathrm{Co}$, and ${ }^{94} \mathrm{Nb}$. In addition, other long-lived radionuclides, such as ${ }^{54} \mathrm{Mn},{ }^{93 \mathrm{~m}} \mathrm{Nb}$, and ${ }^{93} \mathrm{Mo}$ were determined. Cobalt- 60 was the most abundant radionuclide, followed by ${ }^{63} \mathrm{Ni}$ which was present at about $10 \%$ of the ${ }^{60} \mathrm{Co}$ concentration. The ${ }^{60} \mathrm{Co}$ overwhelmingly contributed to the gamma dose from this assembly since ${ }^{63} \mathrm{Ni}$ is a low energy pure beta emitter. The ${ }^{59} \mathrm{Ni}$ was always present at about $1 \%$ of the ${ }^{63} \mathrm{Ni}$ concentration. Niobium-93m (13.8 year half-life) was the third most abundant long-lived radionuclide, being about 300 -fold lower then the ${ }^{60} \mathrm{Co}$ concentrations. This radionuclide is produced primarily by the ${ }^{93} \mathrm{Nb}\left(n, n^{\prime}\right){ }^{93 \mathrm{~m}} \mathrm{Nb}$ reaction and to a lesser extent from the decay of ${ }^{93} \mathrm{Mo}$. The ${ }^{93} \mathrm{Mo}$ ( 3500 years half-life) is produced in relatively low concentrations by neutron activation of stable Mo present in the stainless steel at a concentration of about $2000 \mathrm{ppm}$. No long-lived fission products were present in the steel components of the CRB, but trace quantities of fission products and TRU isostopes were observed in the boron carbide material. The radionuclide concentrations in the stainless steel and boron carbide decreased about 20 to 30 -fold from the insertion ("hot") end of the assembly to the tail end. The gamma dose rate at the insertion end of the CRB peaked at about $2900 \mathrm{R} / \mathrm{h}$ at contact in August, 1990, approximately 15 years after removal from service. 
Element Characterization

Table 4.1 Radionuclide Concentrations Observed in Cruciform Control Rod Blade Samples Concentration in $\mathrm{pCi} / \mathrm{g}^{*}$

\begin{tabular}{|c|c|c|c|c|c|c|c|}
\hline Sample ID & $\mathrm{Mn}-54$ & Co-60 & $\mathrm{Ni}-59$ & $\mathrm{Ni}-63$ & $\mathrm{Nb}-93 \mathrm{~m}$ & $\mathrm{Nb}-94$ & Mo-93 \\
\hline DER-IA & $4.22 E+07$ & $1.10 \mathrm{E}+10$ & $1.01 \mathrm{E}+07$ & $9.92 \mathrm{E}+08$ & $3.02 \mathrm{E}+07$ & \multirow{8}{*}{$7.74 \mathrm{E}+05$} & $1.12 E+04$ \\
\hline DER-1B & $5.59 E+07$ & $1.32 \mathrm{E}+10$ & $1.03 \mathrm{E}+07$ & $9.95 E+08$ & $4.56 \mathrm{E}+07$ & & $1.46 \mathrm{E}+04$ \\
\hline DER-1C & $4.80 \mathrm{E}+07$ & $9.36 \mathrm{E}+09$ & $9.55 \mathrm{E}+06$ & $9.01 E+08$ & $9.41 \mathrm{E}+07$ & & $9.93 E+03$ \\
\hline DER-ID & $2.56 \mathrm{E}+07$ & $8.40 \mathrm{E}+09$ & $9.01 E+06$ & $8.68 \mathrm{E}+08$ & $2.65 \mathrm{E}+07$ & & $1.06 \mathrm{E}+04$ \\
\hline DER-IE & $4.29 E+07$ & $1.46 \mathrm{E}+10$ & $1.47 \mathrm{E}+07$ & $1.48 \mathrm{E}+09$ & $3.14 \mathrm{E}+07$ & & $2.83 E+04$ \\
\hline AVG DER-1 & $4.29 \mathrm{E}+07$ & $1.13 E+10$ & $1.07 \mathrm{E}+07$ & $1.05 E+09$ & $4.56 \mathrm{E}+07$ & & $1.49 \mathrm{E}+04$ \\
\hline \pm & $1.11 E+07$ & $2.59 \mathrm{E}+09$ & $2.27 \mathrm{E}+06$ & $2.48 \mathrm{E}+08$ & $2.81 E+07$ & & $7.69 E+03$ \\
\hline DER-12 Cladding** & $3.91 E+07$ & $8.74 \mathrm{E}+09$ & $1.27 \mathrm{E}+07$ & $1.20 \mathrm{E}+09$ & $7.32 \mathrm{E}+07$ & & $8.46 \mathrm{E}+03$ \\
\hline DER-2B & $2.67 E+07$ & $6.08 \mathrm{E}+09$ & $5.57 \mathrm{E}+06$ & $5.19 E+08$ & $1.37 \mathrm{E}+06$ & \multirow{7}{*}{$7.71 E+04$} & $2.11 \mathrm{E}+03$ \\
\hline DER-2C & $2.65 E+07$ & $7.66 \mathrm{E}+09$ & $6.50 \mathrm{E}+06$ & $6.29 E+08$ & $1.26 E+06$ & & 3. $77 \mathrm{E}+03$ \\
\hline DER-2D & $3.00 \mathrm{E}+07$ & $9.70 E+09$ & $8.17 \mathrm{E}+06$ & $7.33 E+08$ & $1.28 \mathrm{E}+06$ & & $3.02 E+03$ \\
\hline DER-2E & $2.52 \mathrm{E}+07$ & $9.38 \mathrm{E}+09$ & $1.05 \mathrm{E}+07$ & $9.71 E+08$ & $1.38 \mathrm{E}+06$ & & $2.19 \mathrm{E}+03$ \\
\hline AVG DER-2 & $2.71 \mathrm{E}+07$ & $8.21 E+09$ & $7.69 \mathrm{E}+06$ & $7.13 E+08$ & $1.32 \mathrm{E}+06$ & & $2.77 \mathrm{E}+03$ \\
\hline \pm & $2.04 \mathrm{E}+06$ & $1.68 \mathrm{E}+09$ & $2.16 \mathrm{E}+06$ & $1.93 E+08$ & $6.13 E+04$ & & $7.82 E+02$ \\
\hline DER-2Z Cladding** & $3.01 \mathrm{E}+07$ & $5.00 E+09$ & $7.79 \mathrm{E}+06$ & $7.92 \mathrm{E}+08$ & $3.17 E+06$ & & $5.40 \mathrm{E}+03$ \\
\hline DER-3A & $<1.5 \mathrm{E}+06$ & $1.81 E+08$ & $2.32 \mathrm{E}+05$ & $2.08 \mathrm{E}+07$ & $1.70 E+04$ & \multirow{9}{*}{$1.15 E+03$} & $<5.8 \mathrm{E}+02$ \\
\hline DER-3B & $<2.8 \mathrm{E}+06$ & $2.11 E+08$ & $2.77 \mathrm{E}+05$ & $2.78 \mathrm{E}+07$ & $2.61 E+04$ & & $<6.4 \mathrm{E}+02$ \\
\hline DER-3C & $<1.2 \mathrm{E}+07$ & $2.23 E+08$ & $3.07 \mathrm{E}+05$ & $2.99 \mathrm{E}+07$ & $2.57 \mathrm{E}+04$ & & $<4.1 E+02$ \\
\hline DER-3D & $<8.8 \mathrm{E}+06$ & $1.61 E+08$ & $2.90 \mathrm{E}+05$ & $2.55 \mathrm{E}+07$ & $5.62 \mathrm{E}+04$ & & $<2.9 \mathrm{E}+02$ \\
\hline DER-3E & $<1.9 E+06$ & $2.26 \mathrm{E}+08$ & $2.28 \mathrm{E}+05$ & $2.28 \mathrm{E}+07$ & $2.23 \mathrm{E}+04$ & & $<2.8 \mathrm{E}+02$ \\
\hline DER-3F & $<2.9 \mathrm{E}+06$ & $2.70 \mathrm{E}+08$ & $3.75 E+05$ & $3.63 \mathrm{E}+07$ & $2.90 E+04$ & & $<3.2 \mathrm{E}+02$ \\
\hline AVG DER-3 & $<5.0 \mathrm{E}+06$ & $2.12 E+08$ & $2.85 E+05$ & $2.72 \mathrm{E}+07$ & $2.94 E+04$ & & $<4.2 E+02$ \\
\hline \pm & & $3.81 E+07$ & $5.43 E+04$ & $5.54 E+06$ & $1.38 E+04$ & & \\
\hline DER-3Z Cladding** & $<1.4 \mathrm{E}+06$ & $1.19 \mathrm{E}+08$ & $3.49 \mathrm{E}+05$ & $2.66 E+07$ & $4.74 \mathrm{E}+04$ & & $<3.6 \mathrm{E}+02$ \\
\hline
\end{tabular}


Table 4.1 Radionuclide Concentrations Observed in Cruciform Control Rod Blade Samples (Cont'd)

Concentration in $\mathrm{pCi} / \mathrm{g}^{*}$

\begin{tabular}{|c|c|c|c|c|c|c|}
\hline Sample ID & $\mathrm{Sb}-125$ & Cs-134 & Cs- 137 & Eu-152 & Eu-154 & Eu-155 \\
\hline DER-1A & $<6.8 \mathrm{E}+07$ & $<7.0 \mathrm{E}+07$ & $<1.2 \mathrm{E}+07$ & $<7.2 \mathrm{E}+07$ & $<8.7 \mathrm{E}+07$ & $<1.1 \mathrm{E}+07$ \\
\hline DER-1B & $<8.0 \mathrm{E}+07$ & $<8.1 \mathrm{E}+07$ & $<1.4 \mathrm{E}+07$ & $<8.5 E+07$ & $<1.0 \mathrm{E}+08$ & $<1.5 \mathrm{E}+07$ \\
\hline DER-1C & $<4.7 E+07$ & $<4.8 \mathrm{E}+07$ & $<8.2 E+06$ & $<4.9 E+07$ & $<6.0 \mathrm{E}+07$ & $<8.9 E+06$ \\
\hline DER-1D & $<5.5 \mathrm{E}+07$ & $<5.6 \mathrm{E}+07$ & $<9.6 \mathrm{E}+06$ & $<5.7 \mathrm{E}+07$ & $<7.0 \mathrm{E}+07$ & $<9.2 \mathrm{E}+06$ \\
\hline DER-IE & $<9.7 \mathrm{E}+07$ & $<9.9 \mathrm{E}+07$ & $<1.7 \mathrm{E}+07$ & $<9.9 E+07$ & $<1.2 \mathrm{E}+08$ & $<1.6 \mathrm{E}+07$ \\
\hline $\begin{array}{l}\text { AVG DER-1 } \\
\quad \pm\end{array}$ & $<6.9 \mathrm{E}+07$ & $<7.1 \mathrm{E}+07$ & $<1.2 \mathrm{E}+07$ & $<7.2 \mathrm{E}+07$ & $<8.7 E+07$ & $<1.2 \mathrm{E}+07$ \\
\hline DER-1Z Cladding** & $<7.0 \mathrm{E}+07$ & $<7.1 \mathrm{E}+07$ & $<1.2 \mathrm{E}+07$ & $<6.9 \mathrm{E}+07$ & $<8.7 \mathrm{E}+07$ & $\leq 1.2 \mathrm{E}+07$ \\
\hline DER-2B & $<5.1 \mathrm{E}+07$ & $<5.3 \mathrm{E}+07$ & $<8.9 \mathrm{E}+06$ & $<5.1 \mathrm{E}+07$ & $<6.5 \mathrm{E}+07$ & $<8.6 \mathrm{E}+06$ \\
\hline DER-2C & $<5.0 \mathrm{E}+07$ & $<5.3 E+07$ & $<8.8 \mathrm{E}+06$ & $<5.1 \mathrm{E}+07$ & $<6.5 \mathrm{E}+07$ & $<8.5 E+06$ \\
\hline DER-2D & $<6.2 \mathrm{E}+07$ & $<6.3 \mathrm{E}+07$ & $<1.1 \mathrm{E}+07$ & $<6.5 \mathrm{E}+07$ & $<8.0 \mathrm{E}+07$ & $<1.0 \mathrm{E}+07$ \\
\hline DER-2E & $<4.1 E+07$ & $<4.1 E+07$ & $<7.2 \mathrm{E}+06$ & $<4.7 \mathrm{E}+07$ & $<5.3 E+07$ & $<7.7 \mathrm{E}+06$ \\
\hline $\begin{array}{l}\text { AVG DER-2 } \\
\pm\end{array}$ & $<5.1 \mathrm{E}+07$ & $<5.2 \mathrm{E}+07$ & $<9.0 \mathrm{E}+06$ & $<5.4 \mathrm{E}+07$ & $<6.6 \mathrm{E}+07$ & $<8.7 E+06$ \\
\hline DER-2Z Cladding** & $<4.6 \mathrm{E}+07$ & $<8.1 \mathrm{E}+06$ & $<4.7 E+07$ & $<4.7 \mathrm{E}+07$ & $<5.9 \mathrm{E}+07$ & $<7.7 E+06$ \\
\hline DER-3A & $<5.8 \mathrm{E}+06$ & $<6.0 \mathrm{E}+06$ & $<1.0 \mathrm{E}+06$ & $<6.4 \mathrm{E}+06$ & $<6.4 E+06$ & $<1.0 \mathrm{E}+06$ \\
\hline DER-3B & $<1.0 \mathrm{E}+07$ & $<9.2 \mathrm{E}+06$ & $<1.8 \mathrm{E}+06$ & $<1.5 \mathrm{E}+07$ & $<9.7 \mathrm{E}+06$ & $<1.8 \mathrm{E}+06$ \\
\hline DER-3C & & & & & & \\
\hline DER-3D & $<3.4 \mathrm{E}+07$ & $<2.5 E+07$ & $<5.8 E+06$ & $<5.6 \mathrm{E}+07$ & $<4.2 E+07$ & $<6.0 \mathrm{E}+06$ \\
\hline DER-3E & $<7.7 \mathrm{E}+06$ & $<8.3 E+06$ & $<1.2 E+06$ & $<7.3 \mathrm{E}+06$ & $<8.2 E+06$ & $<1.3 \mathrm{E}+06$ \\
\hline DER-3F & $<1.1 \mathrm{E}+07$ & $<1.1 \mathrm{E}+07$ & $<1.8 \mathrm{E}+06$ & $<1.2 \mathrm{E}+07$ & $<1.1 \mathrm{E}+07$ & $<2.0 \mathrm{E}+06$ \\
\hline $\begin{array}{l}\text { AVG DER-3 } \\
\pm\end{array}$ & $<1.4 \mathrm{E}+07$ & $<1.2 \mathrm{E}+07$ & $<2.3 E+06$ & $<1.9 \mathrm{E}+07$ & $<1.6 \mathrm{E}+07$ & $<2.4 \mathrm{E}+06$ \\
\hline DER-3Z Cladding** & $<5.7 E+06$ & $<5.5 \mathrm{E}+06$ & $<9.3 E+05$ & $<7.0 \mathrm{E}+06$ & $<5.2 E+06$ & $<1.1 E+06$ \\
\hline
\end{tabular}

*Activity as of June 1,1993

**The Z-cladding samples were pieces of the outer stainless steel cladding which covered the interior stainless steel tubes (samples $\mathrm{A}$ through $\mathrm{F}$ ) which contained the $\mathrm{B}_{4} \mathrm{C}$ neutron poison material (see Figure 4.2). 
Element Characterization

Table 4.2 Radionuclide Concentrations Observed in Burnable Poison Rod Assembly (BPRA)

Concentration in $\mathrm{pCi} / \mathrm{g}^{*}$

\begin{tabular}{lccccccc}
\hline Sample ID & Mn-54 & Co-60 & Ni-59 & Ni-63 & Nb-93m & Nb-94 & Mo-93 \\
\hline & & & & & & & \\
DER-4 outer** & $<1.3 \mathrm{E}+07$ & $2.83 \mathrm{E}+09$ & $2.22 \mathrm{E}+07$ & $2.32 \mathrm{E}+09$ & $1.35 \mathrm{E}+06$ & $1.63 \mathrm{E}+04$ & $5.17 \mathrm{E}+03$ \\
DER-4 inner*** & $<1.6 \mathrm{E}+06$ & $3.48 \mathrm{E}+08$ & $1.88 \mathrm{E}+07$ & $1.91 \mathrm{E}+09$ & $3.00 \mathrm{E}+06$ & $4.51 \mathrm{E}+04$ & $1.92 \mathrm{E}+04$ \\
& & & & & & & \\
DER-5 outer & $<4.2 \mathrm{E}+06$ & $3.47 \mathrm{E}+09$ & $2.46 \mathrm{E}+07$ & $2.69 \mathrm{E}+09$ & $1.67 \mathrm{E}+06$ & & $7.42 \mathrm{E}+03$ \\
DER-5 inner & $<1.4 \mathrm{E}+06$ & $4.26 \mathrm{E}+08$ & $2.20 \mathrm{E}+07$ & $2.22 \mathrm{E}+09$ & $3.66 \mathrm{E}+06$ & & $1.22 \mathrm{E}+04$ \\
& & & & & & \\
DER-6 outer & $<3.5 \mathrm{E}+06$ & $3.29 \mathrm{E}+09$ & $2.49 \mathrm{E}+07$ & $2.75 \mathrm{E}+09$ & $1.66 \mathrm{E}+06$ & & $2.53 \mathrm{E}+03$ \\
DER-6 inner & $<1.0 \mathrm{E}+06$ & $3.88 \mathrm{E}+08$ & $1.99 \mathrm{E}+07$ & $2.10 \mathrm{E}+09$ & $3.31 \mathrm{E}+06$ & & $9.89 \mathrm{E}+03$ \\
\hline
\end{tabular}

\begin{tabular}{lcccccc}
\hline Sample ID & Sb-125 & Cs-134 & Cs-137 & Eu-152 & Eu-154 & Eu-155 \\
\hline DER-4 outer & $<6.4 \mathrm{E}+07$ & $<5.8 \mathrm{E}+07$ & $<9.9 \mathrm{E}+06$ & $<2.5 \mathrm{E}+07$ & $<5.3 \mathrm{E}+07$ & $<1.8 \mathrm{E}+07$ \\
DER-4 inner & $<8.5 \mathrm{E}+06$ & $<1.3 \mathrm{E}+06$ & $<1.3 \mathrm{E}+06$ & $<3.6 \mathrm{E}+06$ & $<6.4 \mathrm{E}+06$ & $5.03 \mathrm{E}+06$ \\
& & & & & & \\
DER-5 outer & $<2.2 \mathrm{E}+07$ & $<2.0 \mathrm{E}+07$ & $<3.5 \mathrm{E}+06$ & $<7.9 \mathrm{E}+06$ & $<2.3 \mathrm{E}+07$ & $5.03 \mathrm{E}+07$ \\
DER-5 inner & $<7.4 \mathrm{E}+06$ & $<6.1 \mathrm{E}+06$ & $<1.2 \mathrm{E}+06$ & $<2.1 \mathrm{E}+06$ & $<6.5 \mathrm{E}+06$ & $<2.1 \mathrm{E}+06$ \\
& & & & & & \\
DER-6 outer & $<1.8 \mathrm{E}+07$ & $<1.7 \mathrm{E}+07$ & $<2.9 \mathrm{E}+06$ & $<7.4 \mathrm{E}+06$ & $<2.0 \mathrm{E}+07$ & $5.40 \mathrm{E}+06$ \\
DER-6 inner & $<5.5 \mathrm{E}+06$ & $<4.6 \mathrm{E}+06$ & $<8.7 \mathrm{E}+05$ & $<1.3 \mathrm{E}+06$ & $<5.1 \mathrm{E}+06$ & $4.98 \mathrm{E}+06$ \\
\hline
\end{tabular}

* Activity as of June 1, 1993

** - Samples of the outer stainless steel tube which served as the outer cladding of the borosilicate glass poison tube

***- Samples of the inner stainless steel tube which served as the inner cladding of the borosilicate glass poison tube 
Element Characterization

Table 4.3 Radionuclide Concentrations Observed in Reactor Rod Cluster Control Assembly (RCCA) Samples Concentration in $\mathrm{pCi} / \mathrm{g}$ (as of $6 / 1 / 93$ )

Type 304 Stainless Steel Cladding Samples, Ag-In-Cd Alloy, and Stainless SteelControl Rod Tip (RCCA-8 ss)

\begin{tabular}{|c|c|c|c|c|c|c|c|c|c|c|}
\hline Sample ID & $\mathrm{Na}-22$ & $\mathrm{AJ}=26$ & $M n-54$ & $\mathrm{Co}-60$ & Ni-59 & $\mathrm{Ni}-63$ & $\mathrm{Nb}-93 \mathrm{~m}$ & $\mathrm{Nb}-94$ & Mo-93 & Ag- $108 \mathrm{~m}$ \\
\hline $\begin{array}{l}\text { DER-7 ss } \\
\text { DER-7 Ag-In-Cd }\end{array}$ & & & $<14$ & $\begin{array}{l}1.22 \mathrm{E}+03 \\
3.79 \mathrm{E}+02\end{array}$ & $<26$ & $5.87 \mathrm{E}+02$ & & & & $5.4 \bar{E}+03$ \\
\hline $\begin{array}{l}\text { DER-8 ss } \\
\text { DER-8 Ag-In-Cd }\end{array}$ & & & $<62$ & $\begin{array}{l}2.67 \mathrm{E}+03 \\
9.71 \mathrm{E}+02\end{array}$ & 22 & $1.43 E+03$ & & & & $1.1 \bar{E}+04$ \\
\hline $\begin{array}{l}\text { DER-9 ss } \\
\text { DER-9 Ag-In-Cd }\end{array}$ & $<4$ & $\therefore 4$ & $2.18 E+02$ & $\begin{array}{l}3.33 \mathrm{E}+05 \\
7.09 \mathrm{E}+03\end{array}$ & $2.69 \mathrm{E}+03$ & $2.46 E+05$ & & & & $1.1 \overline{\mathrm{E}}+06$ \\
\hline $\begin{array}{l}\text { DER-10 A ss } \\
\text { DER-10 A Ag-In-Cd }\end{array}$ & $<2.2 \mathrm{E}+04$ & $\because 1.4 \mathrm{E}+04$ & $\begin{array}{l}1.1 E+07 \\
3.1 E+07\end{array}$ & $\begin{array}{l}2.99 \mathrm{E}+10 \\
1.68 \mathrm{E}+09\end{array}$ & $\begin{array}{l}2.87 \mathrm{E}+07 \\
4.70 \mathrm{E}+02\end{array}$ & $\begin{array}{l}2.93 E+09 \\
6.31 E+04\end{array}$ & $\begin{array}{l}3.60 \mathrm{E}+07 \\
8.08 \mathrm{E}+04\end{array}$ & $5.44 \mathrm{E}+05$ & $2.07 E+04$ & $2.1 \overline{4 E}+10$ \\
\hline $\begin{array}{l}\text { DER-10 B ss } \\
\text { DER-10 B Ag-In-Cd }\end{array}$ & & & $\begin{array}{l}\because 1.1 \mathrm{E}+08 \\
-4.4 \mathrm{E}+07\end{array}$ & $\begin{array}{l}3.75 \mathrm{E}+10 \\
2.97 \mathrm{E}+09\end{array}$ & $\begin{array}{l}4.16 \mathrm{E}+07 \\
1.70 \mathrm{E}+03\end{array}$ & $\begin{array}{l}4.15 E+09 \\
1.01 E+05\end{array}$ & $2.09 \mathrm{E}+07$ & & $\begin{array}{l}2.31 E+04 \\
<1.3 E+02\end{array}$ & $\begin{array}{l}8.92 \mathrm{E}+07 \\
2.73 \mathrm{E}+10\end{array}$ \\
\hline RCCA - 8 ss* & & & $1.11 \mathrm{E}+07$ & $6.49 E+09$ & $7.18 \mathrm{E}+07$ & $8.24 E+09$ & $1.19 \mathrm{E}+06$ & & $1.44 E+04$ & \\
\hline
\end{tabular}

\begin{tabular}{|c|c|c|c|c|c|c|c|c|c|}
\hline Sample ID & $\mathrm{Ag}-110 \mathrm{~m}$ & Cd-109 & Cd-113m & $\mathrm{Sb}-125$ & Cs-134 & Cs-137 & Eu-152 & Eu-154 & Eu-155 \\
\hline $\begin{array}{l}\text { DER-7 ss } \\
\text { DER-7 Ag-In-Cd }\end{array}$ & $1.55 \mathrm{E}+02$ & & & & $\begin{array}{l}<74 \\
<40\end{array}$ & $\begin{array}{l}<13 \\
<7\end{array}$ & $\begin{array}{l}-110 \\
-36\end{array}$ & $\begin{array}{l}<94 \\
<180\end{array}$ & $\begin{array}{l}<22 \\
<12\end{array}$ \\
\hline $\begin{array}{l}\text { DER-8 ss } \\
\text { DER-8 Ag-In-Cd }\end{array}$ & $3.82 \mathrm{E}+02$ & & & 214 & $\begin{array}{c}<.7 E+02 \\
<53\end{array}$ & $\begin{array}{l}<56 \\
<9\end{array}$ & $\begin{array}{c}<6.0 E+02 \\
<43\end{array}$ & $\begin{array}{c}3.5 E+02 \\
370\end{array}$ & $\begin{array}{l}<81 \\
<15\end{array}$ \\
\hline $\begin{array}{l}\text { DER-9 ss } \\
\text { DER-9 Ag-In-Cd }\end{array}$ & $3.96 \mathrm{E}+04$ & $8.59 E+03$ & $5.15 E+05$ & $<2.7 \mathrm{E}+03$ & $\begin{array}{l}<2.8 \mathrm{E}+03 \\
-3.6 \mathrm{E}+02\end{array}$ & $\begin{array}{c}<4.6 \mathrm{E}+02 \\
<65\end{array}$ & $\begin{array}{l}<2.6 \mathrm{E}+03 \\
<1.9 \mathrm{E}+02\end{array}$ & $\begin{array}{c}<3.3 E+03 \\
3240\end{array}$ & $\begin{array}{l}460 \\
215\end{array}$ \\
\hline $\begin{array}{l}\text { DER-10 A ss } \\
\text { DER-10 A Ag-ln-Cd }\end{array}$ & $1.48 \mathrm{E}+09$ & $6.85 E+06$ & $4.93 E+08$ & $\begin{array}{l}<4.4 \mathrm{E}+07 \\
<2.9 \mathrm{E}+08\end{array}$ & $\begin{array}{l}<4.8 E+07 \\
<2.0 E+08\end{array}$ & $\begin{array}{l}<7.2 E+06 \\
<3.4 E+07\end{array}$ & $\begin{array}{l}<4.0 \mathrm{E}+07 \\
<1.2 \mathrm{E}+08\end{array}$ & $\begin{array}{l}<5.3 E+07 \\
<8.7 E+08\end{array}$ & $\begin{array}{l}<7.3 E+06 \\
<6.5 E+07\end{array}$ \\
\hline $\begin{array}{l}\text { DER-10 B ss } \\
\text { DER-10 B Ag-in-Cd }\end{array}$ & $2.32 \mathrm{E}+09$ & $1.42 \mathrm{E}+07$ & $8.68 \mathrm{E}+08$ & $\begin{array}{l}<4.2 \mathrm{E}+08 \\
<4.0 \mathrm{E}+08\end{array}$ & $\begin{array}{l}<4.5 \mathrm{E}+08 \\
<3.0 \mathrm{E}+08\end{array}$ & $\begin{array}{l}<6.8 \mathrm{E}+07 \\
<4.9 \mathrm{E}+07\end{array}$ & $\begin{array}{l}<3.8 \mathrm{E}+08 \\
<1.8 \mathrm{E}+08\end{array}$ & $\begin{array}{l}<4.9 E+08 \\
<1.4 E+09\end{array}$ & $\begin{array}{l}<6.9 \mathrm{E}+07 \\
<8.7 \mathrm{E}+07\end{array}$ \\
\hline $\mathrm{RCCA}-8 \mathrm{ss}$ & & & & $<5,9 \mathrm{E}+07$ & $<5.2 \mathrm{E}+07$ & $<9,4 E+06$ & $<1.5 E+07$ & $<6.0 \mathrm{E}+07$ & $1.01 e+08$ \\
\hline
\end{tabular}

*A sample of RCCA-8, the stainless steel tip end of the insertion end of RCCA was sampled by Migliori, et al., 1994 and shared with us for radiochemical analyses and comparison of results. 
Element Characterization

Table 4.4 Radionuclide Concentrations in Boron Carbide Material from Cruciform Control Rod Blade (CRB) Samples Concentration in $\mathrm{pCi} / \mathrm{g}$ (as of 6/1/93)

\begin{tabular}{lcccccccc}
\hline Sample ID & Na-22 & Al-26 & Mn-54 & Co-60 & Nb-94 & Sb-125 & Cs-134 & Cs-137 \\
\hline DER-1 & $<1.6 \mathrm{E}+04$ & & $1.87 \mathrm{E}+05$ & $1.06 \mathrm{E}+07$ & $<2.6 \mathrm{E}+04$ & $<1.4 \mathrm{E}+05$ & $<1.4 \mathrm{E}+05$ & $8.69 \mathrm{E}+04$ \\
DER-2 & $<49$ & $<92$ & $1.86 \mathrm{E}+05$ & $5.71 \mathrm{E}+06$ & $<1.3 \mathrm{E}+04$ & $<7.0 \mathrm{E}+04$ & $<7.1 \mathrm{E}+04$ & $2.67 \mathrm{E}+04$ \\
DER-3 & $<41$ & $<84$ & $<5.4 \mathrm{E}+03$ & $5.68 \mathrm{E}+05$ & $<3.6 \mathrm{E}+03$ & $<2.2 \mathrm{E}+04$ & $<1.5 \mathrm{E}+04$ & $1.99 \mathrm{E}+05$ \\
\hline
\end{tabular}

\begin{tabular}{|c|c|c|c|c|c|c|c|c|}
\hline Sample ID & Eu-152 & Eu-154 & Eu-155 & Pu-238 & $\mathrm{Pu}-39 / 240$ & $\mathrm{Pu}-241$ & Am-241 & $\mathrm{Cm}-244$ \\
\hline DER-1 & $4.09 E+04$ & $8.56 \mathrm{E}+04$ & $<6.3 \mathrm{E}+04$ & $1.64 E+04$ & $6.34 E+03$ & $4.65 \mathrm{E}+05$ & $6.80 E+03$ & $1.25 \mathrm{E}+04$ \\
\hline DER-2 & $4.50 \mathrm{E}+04$ & $4.82 \mathrm{E}+04$ & $3.1 \mathrm{E}+04$ & & & & & \\
\hline DER-3 & $<1.7 \mathrm{E}+04$ & $<1.6 \mathrm{E}+04$ & $<8.0 \mathrm{E}+04$ & & & & & \\
\hline
\end{tabular}

Table 4.5 Radionuclide Concentrations Observed in Borosilicate Glass Specimens from the Burnable Poison Rod Assembly (BPRA) Samples

Concentration in $\mathrm{pCi} / \mathrm{g}$ (as of $6 / 1 / 93$ )

\begin{tabular}{lcccccccc}
\hline Sample ID & Na-22 & Al-26 & Mn-54 & Co-60 & Sb-125 & Ba-133 & Cs-134 & Cs-137 \\
\hline DER-4 & $4.85 \mathrm{E}+02$ & $<4.1$ & $<1.8 \mathrm{E}+03$ & $9.96 \mathrm{E}+05$ & $4.96 \mathrm{E}+03$ & $1.55 \mathrm{E}+04$ & $6.60 \mathrm{E}+03$ & $2.17 \mathrm{E}+04$ \\
DER-5 & $5.85 \mathrm{E}+02$ & $<6.6$ & $<1.9 \mathrm{E}+03$ & $1.15 \mathrm{E}+06$ & $7.35 \mathrm{E}+03$ & $1.38 \mathrm{E}+04$ & $6.96 \mathrm{E}+03$ & $2.76 \mathrm{E}+04$ \\
DER-6 & $6.89 \mathrm{E}+02$ & -5.2 & $<\mathrm{LE}+03$ & $101 \mathrm{E}+06$ & $6.79 \mathrm{E}+03$ & $1.29 \mathrm{E}+04$ & $7.49 \mathrm{E}+03$ & $2.40 \mathrm{E}+04$ \\
\hline
\end{tabular}

\begin{tabular}{lcccccccc}
\hline Sample ID & Eu-152 & Eu-154 & Eu-155 & Pu-238 & Pu-239/240 & Pu-241 & Am-241 & Cm-244 \\
\hline DER-4 & $2.03 \mathrm{E}+04$ & $4.62 \mathrm{E}+05$ & $1.47 \mathrm{E}+05$ & & & & & \\
DER-5 & $8.15 \mathrm{E}+03$ & $4.80 \mathrm{E}+05$ & $1.49 \mathrm{E}+05$ & & & & & \\
DER-6 & $1.67 \mathrm{E}+04$ & $4.74 \mathrm{E}+05$ & $1.52 \mathrm{E}+05$ & $1.02 \mathrm{E}+02$ & $5.73 \mathrm{E}+02$ & $6.51 \mathrm{E}+04$ & $2.55 \mathrm{E}+03$ & $1.08 \mathrm{E}+02$ \\
\hline
\end{tabular}


The boron carbide from the BWR control rod was dominated by ${ }^{60} \mathrm{Co}$, but also observed by instrumental analysis was ${ }^{137} \mathrm{Cs}$, ${ }^{152} \mathrm{Eu}$, and ${ }^{154} \mathrm{Eu}$. Radiochemical determinations also showed the presence of ${ }^{238} \mathrm{Pu},{ }^{239 / 240} \mathrm{Pu}$, ${ }^{24 \mathrm{I}} \mathrm{Pu},{ }^{24 \mathrm{l}} \mathrm{Am}$, and ${ }^{244} \mathrm{Cm}$.

The Ag-In-Cd control rod was unique in its elemental makeup, and consequently, the presence of ${ }^{108 \mathrm{~m}} \mathrm{Ag},{ }^{110 \mathrm{~m}} \mathrm{Ag}$, ${ }^{109} \mathrm{Cd}$, and ${ }^{113 \mathrm{~m}} \mathrm{Cd}$ was also determined. Indium does not produce any long-lived neutron activation product radioisotopes. It is important to note that the activity of ${ }^{108 \mathrm{~m}} \mathrm{Ag}$ was as great or greater than the activity of ${ }^{60} \mathrm{Co}$. Silver- $108 \mathrm{~m}$, with a half-life of 130 years, will be the most abundant radionuclide in this type of control rod (RCCA) for hundreds of years, and will need to be considered in the disposal of these types of control rods. Silver-108 decays mainly by electron capture accompied by the emission of three relatively high energy gamma rays $(439,614$, and 722 $\mathrm{keV}$ ) each at $91 \%$ relative intensity, and therefore has a relatively high gamma dose conversion factor. On a per gram basis, the concentration of ${ }^{108 \mathrm{~m}} \mathrm{Ag}$ in this alloy is comparable to the ${ }^{60} \mathrm{Co}$ concentrations in the stainless steel cladding, but the mass of the $\mathrm{Ag} / \mathrm{In} / \mathrm{Cd}$ alloy greatly exceeds that of the stainless steel cladding. Therefore, the ${ }^{108 \mathrm{~m}} \mathrm{Ag}$ will be the dominant gamma dose-contributing radionuclide in this type of control rod assembly for many hundreds of years. Silver-108m is not addressed in 10CFR61, so it cannot be considered in waste classification assessments for this assembly.

The RCCA was fully withdrawn at all times during full power operations and only the first few tens of $\mathrm{cm}$ on the insertion end of the RCCA were highly neutron activated. The gamma dose rate at the insertion end peaked at about $290 \mathrm{R} / \mathrm{h}$ at contact in August 1990.

The Ag-In-Cd alloy in the RCCA also contained two longlived $\mathrm{Cd}$ neutron activation products, ${ }^{109} \mathrm{Cd}$ ( 453 days halflife) and ${ }^{113 \mathrm{~m}} \mathrm{Cd}$ (13.7 years half-life). The ${ }^{113 \mathrm{~m}} \mathrm{Cd}$, because of its greater abundance and longer half-life is the more important from waste disposal considerations. The ${ }^{113 \mathrm{~m}} \mathrm{Cd}$ decays by emission of a medium energy $(590 \mathrm{keV})$ beta particle and a very low relative intensity $264 \mathrm{keV}$ gamma ray from a $0.1 \%$ isomeric transistion. The ${ }^{113 m} \mathrm{Cd}$ concentrations in the neutron poison alloy of the $\mathrm{CRB}$ were about 30 -fold lower than the ${ }^{108 m} \mathrm{Ag}$ concentrations.

The PWR Burnable Poison Rod Assembly, composed of stainless steel clad borosilicate glass, likewise contained predominantly ${ }^{60} \mathrm{Co}$ produced from $1600 \mathrm{ppm}$ of cobalt present in the steel. This steel likewise contained similar amounts of ${ }^{63} \mathrm{Ni},{ }^{93 \mathrm{~m}} \mathrm{Nb},{ }^{99} \mathrm{Ni}$, and ${ }^{94} \mathrm{Nb}$, relative to the ${ }^{60} \mathrm{Co}$, as observed in the CRB. The concentrations of the activation products were rather uniformly distributed over the length of the neutron-absorbing section of the BPRA.

The gamma dose rate over this section was about $120 \mathrm{R} / \mathrm{h}$ at contact in August, 1990. The borosilicate glass found in the BPRA was dominated by ${ }^{60} \mathrm{Co}$ activity, and the radioisotopes ${ }^{125} \mathrm{Sb},{ }^{134} \mathrm{Cs},{ }^{137} \mathrm{Cs},{ }^{152} \mathrm{Eu},{ }^{154} \mathrm{Eu}$, and ${ }^{155} \mathrm{Eu}$ were also determined instrumentally. In addition, ${ }^{238} \mathrm{Pu},{ }^{239 / 240} \mathrm{Pu}$, ${ }^{241} \mathrm{Am}$ and ${ }^{244} \mathrm{Cm}$ were determined by radiochemical methods. These would appear to be present as the result of uranium impurities in the glass. All of the radionuclides in the glass contributed insignificantly to the waste classification of the BPRA.

\subsection{Stable Element Analysis by ICP/MS}

Knowledge of the chemical composition of the various components found in the control rod assemblies is necessary if one wants to predict the neutron activation products present after some period of neutron exposure. Therefore, dissolved aliquots of the metal specimens from the control rods, dissolved aliquots of the boron carbide collected from the CRB samples, and dissolved aliquots of the borosilicate glass were analyzed for their major, minor, and trace elements. Because these materials had already been irradiated, it was not a simple task to determine the chemical composition because of the requirement to handle high-dose rate materials. At PNL, an inductively coupled plasma/mass spectrometer (ICP/MS) has been modified to accommodate radioactive materials for multi-element analyses (Wyse 1993). Representative samples of the type 304 stainless steel obtained from the cladding of the control rods were chosen as well as an aliquot from each CRB sample that contained boron carbide and each BPRA that contained the borosilicate glass. Of concern, was the possibility of burnup of some of the elements that might alter the analytical results. This depletion would vary with each control rod and each sample because of the varying neutron exposure both due to time of exposure and location relative to the reactor core.

Briefly, the ICP/MS is operated by taking a liquid aliquot and aspirating it through a pneumatic nebulizer which mixes it with argon to form an aerosol. The aerosol is injected into the inductively coupled plasma where the plasma atomizes and ionizes the aerosol. This ion beam is then focused and sent through a quadrapole mass spectrometer which separates the ions according to mass per unit charge $(\mathrm{m} / \mathrm{z})$. Ions are detected with an electron multiplier and by varying the radio frequency/magnetic fields of the quadrapole, the masses of interest can be scanned. The concentration results are obtained by ratioing count rates for known isotopic ratios to the count rates obtained for the unknown samples. Therefore, it is very 
important that the ICP/MS analyst not choose an isotope for the standard that becomes depleted after neutron exposure in the reactor core. Also, one wants the quantity of a element at the beginning of exposure, not at some later time because that is what is needed for predictive modeling.

The major, minor, and trace elements that were measured in the type 304 stainless steel samples from each assembly and the Ag-In-Cd absorber in the RCCA samples are listed in Table 4.6. Evans, et al. (1984) reported a composition summary of Type 304 stainless steel samples obtained from a number of commercial reactors. The reported average concentrations for $\mathrm{Cr}, \mathrm{Mn}, \mathrm{Fe}, \mathrm{Ni}$, and $\mathrm{Mo}$ were $18.4 \pm$ $1.1 \%, 1.53 \pm 0.28 \%, 70.6 \pm 2.6 \%, 10.0 \pm 0.7 \%$, and $0.26 \pm$ $0.15 \%$, respectively. Table 4.6 shows considerable variability in the concentrations observed for $\mathrm{Cr}, \mathrm{Mn}, \mathrm{Fe}$, $\mathrm{Ni}$, and Mo from one set of control rod samples to another.

\subsubsection{Type 304 Stainless Steel Samples from the CRB, BPRA, and RCCA}

The measured concentration results for the type 304 stainless steel samples obtained from the three control rods are listed in Table 4.6. There appears to be reasonable agreement with the data reported by Evans et al. (1988) for 304 stainless steel compared to that of the CRB although it appears that the concentrations of $\mathrm{Fe}$ and $\mathrm{Ni}$ in the $\mathrm{CRB}$ are slightly higher. The mass balance appears reasonable. The BPRA samples appear to have a higher concentration of $\mathrm{Cr}$ and Ni compared to the data reported by Evans et al. (1988), thus resulting in mass balances of 112 and 130 . The fact that the concentration of Fe in the DER- 6 outer sample is less than that of the DER- 6 inner is consistent with the theory that the outer tube was exposed to a higher neutron flux compared to the inner tube because of the borosilicate glass (neutron poison) tube between the inner and outer stainless steel tubes. The RCCA samples were high in $\mathrm{Cr}$ and $\mathrm{Fe}$ compared to the ranges reported by Evans et al., (1988). In fact, the mass balances for these two samples were 121 and $134 \%$.

\subsubsection{Ag-In-Cd Metal Sample from the RCCA}

The composition of the absorber used in the RCCA has been reported to be $80 \% \mathrm{Ag}, 15 \% \mathrm{In}$, and $5 \% \mathrm{Cd}$. Table 4.6 lists the major, minor, and trace elements found in the Ag-In-Cd rod. The measured results were 93\% and $83 \%$ $\mathrm{Ag}$ in samples from DER-7 and -9 . The measured In was $16 \%$ for both samples and the measured $\mathrm{Cd}$ was about $5.4 \%$. The mass balances were $114.5 \%$ and $105.5 \%$, respectively.

\subsubsection{Boron Carbide from the Control Rod Blade (CRB) Samples}

The measured data for the boron carbide is listed in Table 4.7. It was not possible to measure the $C$ content in these samples since the $C$ analyzer had been removed from the hot cell. The concentration of $\mathrm{B}$ was not determined. However, there were small amounts of $\mathrm{Al}, \mathrm{Mn}, \mathrm{Co}$, and $\mathrm{Ba}$ measured in the $\mathrm{B}_{4} \mathrm{C}$. Of these, the most abundant was $\mathrm{Co}$, being present at about $3 \%$.

\subsubsection{Borosilicate Glass from the Burnable Poison Rod Assembly (BPRA) Samples}

Some of the major, minor, and trace elements found in the borosilicate glass are reported in Table 4.7. The four dominant elements measured were $\mathrm{Al}, \mathrm{Na}, \mathrm{B}$, and $\mathrm{Li}$. The neutron absorbing elements were the $\mathrm{B}$ and $\mathrm{Li}$.

In addition, ${ }^{10} \mathrm{~B}$ and ${ }^{11} \mathrm{~B}$ were measured in the glass samples to obtain their isotopic ratios. It has been suggested that the ratio ${ }^{10} \mathrm{~B} /{ }^{11} \mathrm{~B}$ would be a good indicator of the neutron fluence that the highly irradiated metals were exposed to. The ratio of ${ }^{10} \mathrm{~B} /{ }^{11} \mathrm{~B}$ would be an indicator of the thermal neutron exposure. The isotopic ratio $\left({ }^{10} \mathrm{~B} /{ }^{11} \mathrm{~B}\right)$ for normally abundant ${ }^{10} \mathrm{~B}$ and ${ }^{11} \mathrm{~B}$ is 0.248 . In samples of the glass for DER-4, DER-5, and DER- 6 , the ${ }^{10} \mathrm{~B} /{ }^{1 /} \mathrm{B}$ ratios were measured to be $0.014 \pm 0.002,0.007 \pm 0.001$, and $0.011 \pm$ 0.002 , respectively, indicating substantial burnup.

\subsection{Comparison to Other Reported Radioanalytical Measurements}

As mentioned in the introduction, this program was related to a DOE-sponsored program that was designed to measure a limited number of nuclides in the control rod specimens. The DOE data are reported in a document titled "Non-Fuel Assembly Components: 10 CFR 61.55 Classification for Waste Disposal" by R. J. Migliore, et al. (1994). Migliore et al. reported concentration data for only six radionuclides $\left({ }^{14} \mathrm{C},{ }^{60} \mathrm{Co},{ }^{59} \mathrm{Ni},{ }^{63} \mathrm{Ni},{ }^{94} \mathrm{Nb}\right.$, and $\left.{ }^{99} \mathrm{Tc}\right)$ and only for the stainless steel cladding on each assembly. Table 4.8 lists their data along with our data for comparison of analytical results. This work has determined four of the nuclides that were also determined by Migliore et al. (1994). 
Table 4.6 Major, Minor, and Trace Elements Determined in Metal Samples

Concentration in ug/g

\begin{tabular}{|c|c|c|c|c|c|c|c|c|}
\hline Sample ID & $\mathrm{Cr}$ & Mn & $\mathrm{Fe}$ & Co & $\mathrm{Ni}$ & $\mathrm{Cu}$ & $\mathrm{Zn}$ & $\mathrm{Zr}$ \\
\hline \multicolumn{9}{|c|}{ Cruciform Control Rod Blade (CRB) - Stainless Steel } \\
\hline $\begin{array}{l}\text { DER-1E } \\
\quad \pm\end{array}$ & $1.51 \mathrm{E}+05$ & $7.37 \mathrm{E}+03$ & $5.93 \mathrm{E}+05$ & $2.95 \mathrm{E}+03$ & $9.79 \mathrm{E}+04$ & $\begin{array}{l}4.10 \mathrm{E}+03 \\
1.52 \mathrm{E}+03\end{array}$ & $\begin{array}{l}1.64 \mathrm{E}+03 \\
1.21 \mathrm{E}+03\end{array}$ & $2.90 \mathrm{E}+03$ \\
\hline $\begin{array}{l}\text { DER-3D } \\
\quad \pm\end{array}$ & $2.19 \mathrm{E}+05$ & $2.05 \mathrm{E}+04$ & $7.71 \mathrm{E}+05$ & $2.87 \mathrm{E}+03$ & $1.18 \mathrm{E}+05$ & 4.23E+03 & $\begin{array}{l}2.03 E+03 \\
4.36 E+02\end{array}$ & $\begin{array}{l}4.25 E+03 \\
1.58 E+03\end{array}$ \\
\hline $\begin{array}{l}\text { DER-3D (Dup) } \\
\quad \pm\end{array}$ & $2.12 \mathrm{E}+05$ & $1.76 \mathrm{E}+04$ & $7.71 \mathrm{E}+05$ & $2.46 \mathrm{E}+03$ & $1.14 \mathrm{E}+05$ & 4.17E+03 & $\begin{array}{l}5.50 \mathrm{E}+02 \\
5.38 \mathrm{E}+02\end{array}$ & $4.97 \mathrm{E}+02$ \\
\hline $\begin{array}{l}\text { DER-3E } \\
\quad \pm\end{array}$ & $2.00 \mathrm{E}+05$ & $9.42 \mathrm{E}+03$ & $7.43 E+05$ & $3.70 \mathrm{E}+03$ & $1.14 \mathrm{E}+05$ & $4.57 \mathrm{E}+03$ & $\begin{array}{l}7.67 \mathrm{E}+02 \\
4.56 \mathrm{E}+02\end{array}$ & $5.27 \mathrm{E}+02$ \\
\hline $\begin{array}{c}\text { DER-3Z } \\
\pm\end{array}$ & $1.91 \mathrm{E}+05$ & $2.10 \mathrm{E}+04$ & $\begin{array}{l}7.10 \mathrm{E}+05 \\
9.68 \mathrm{E}+04\end{array}$ & $2.27 \mathrm{E}+03$ & $1.13 \mathrm{E}+05$ & $3.51 \mathrm{E}+03$ & $3.12 \mathrm{E}+03$ & $\begin{array}{l}1.51 E+03 \\
5.56 E+02\end{array}$ \\
\hline \multicolumn{9}{|c|}{ Burnable Poison Rod Assembly (BPRA) - Stainless Steel } \\
\hline $\begin{array}{l}\text { DER-4 outer } \\
\quad \pm\end{array}$ & $2.65 \mathrm{E}+05$ & $1.92 \mathrm{E}+04$ & $7.03 \mathrm{E}+05$ & $1.3 \mathrm{IE}+03$ & $1.26 \mathrm{E}+05$ & $1.16 \mathrm{E}+03$ & $7.56 \mathrm{E}+02$ & $1.62 \mathrm{E}+02$ \\
\hline $\begin{array}{l}\text { DER-6 outer } \\
\pm\end{array}$ & $2.42 E+05$ & $2.11 \mathrm{E}+04$ & $7.09 \mathrm{E}+05$ & $1.61 \mathrm{E}+03$ & $1.38 \mathrm{E}+05$ & $1.15 \mathrm{E}+03$ & $<9.96 \mathrm{E}+00$ & $\begin{array}{l}3.98 \mathrm{E}+01 \\
1.39 \mathrm{E}+01\end{array}$ \\
\hline DER-6 inner & $2.27 \mathrm{E}+05$ & $1.91 \mathrm{E}+04$ & $7.85 \mathrm{E}+05$ & $1.90 \mathrm{E}+03$ & $1.57 \mathrm{E}+05$ & $2.13 E+03$ & $1.94 \mathrm{E}+03$ & $2.86 \mathrm{E}+02$ \\
\hline \multicolumn{9}{|c|}{ Reactor Rod Cluster Control Assembly (RCCA) - Stainless Steel (ss) and Ag-In-Cd Alloy (Ag) } \\
\hline $\begin{array}{l}\text { DER-7 ss } \\
\pm\end{array}$ & $2.83 \mathrm{E}+05$ & $2.07 \mathrm{E}+04$ & $7.53 \mathrm{E}+05$ & 8.47E+02 & $1.45 \mathrm{E}+05$ & $1.36 \mathrm{E}+03$ & $<9.92 \mathrm{E}+00$ & $3.89 \mathrm{E}+01-$ \\
\hline $\begin{array}{l}\text { DER-9 ss } \\
\quad \pm\end{array}$ & $3.35 \mathrm{E}+05$ & $2.00 \mathrm{E}+04$ & $8.01 \mathrm{E}+05$ & $6.02 \mathrm{E}+02$ & $1.47 \mathrm{E}+05$ & $1.56 \mathrm{E}+03$ & $1.30 \mathrm{E}+03$ & $\begin{array}{l}1.19 E+02 \\
4.28 E+01\end{array}$ \\
\hline $\begin{array}{l}\text { DER-7 Ag } \\
\quad \pm\end{array}$ & $<1.55 \mathrm{E}+00$ & $<1.55 \mathrm{E}+00$ & $1.55 \mathrm{E}+01$ & $6.13 \mathrm{E}+01$ & $7.54 \mathrm{E}+02$ & $8.04 E+02$ & $3.79 \mathrm{E}+02$ & $7.00 \mathrm{E}+00$ \\
\hline $\begin{array}{c}\text { DER-9 Ag } \\
\quad \pm\end{array}$ & $2.16 \mathrm{E}+00$ & $2.16 \mathrm{E}+00$ & $2.16 \mathrm{E}+01$ & $6.86 \mathrm{E}+01$ & $9.32 E+02$ & $9.19 E+02$ & $4.60 \mathrm{E}+02$ & $\begin{array}{l}1.29 \mathrm{E}+01 \\
4.96 \mathrm{E}+00\end{array}$ \\
\hline $\begin{array}{c}\text { DER-9 Ag (Dup) } \\
\pm\end{array}$ & $<.16 E+00$ & $<2.16 \mathrm{E}+00$ & $2.16 \mathrm{E}+01$ & $6.82 \mathrm{E}+01$ & $1.20 \mathrm{E}+03$ & $8.72 E+02$ & $3.84 E+02$ & $\begin{array}{l}9.49 \mathrm{E}+00 \\
3.88 \mathrm{E}+00 \\
\end{array}$ \\
\hline
\end{tabular}


Element Characterization

Table 4.6 Major, Minor, and Trace Elements Determined in Metal Samples (Cont'd)

Concentration in $\mathrm{ug} / \mathrm{g}$

\begin{tabular}{|c|c|c|c|c|c|c|c|c|}
\hline Sample ID & $\mathrm{Nb}$ & Mo & $\mathrm{Ag}$ & $\mathrm{Cd}$ & In & Sn & $\mathrm{Sb}$ & $\mathbf{P b}$ \\
\hline \multicolumn{9}{|c|}{ Cruciform Control Rod Blade (CRB) } \\
\hline $\begin{array}{c}\text { DER-1E } \\
\pm\end{array}$ & $<1.01 \mathrm{E}+02$ & $8.83 \mathrm{E}+02$ & $<1.01 E+02$ & & & $\begin{array}{l}1.11 E+02 \\
8.04 E+01\end{array}$ & $<1.01 \mathrm{E}+02$ & $\begin{array}{l}2.20 \mathrm{E}+03 \\
1.08 \mathrm{E}+03\end{array}$ \\
\hline $\begin{array}{l}\text { DER-3D } \\
\quad \pm\end{array}$ & $<5.98 \mathrm{E}+01$ & $1.79 E+03$ & $<5.98 \mathrm{E}+01$ & & & $8.73 E+01$ & $<5.98 \mathrm{E}+01$ & $\begin{array}{l}6.34 \mathrm{E}+02 \\
3.71 \mathrm{E}+02\end{array}$ \\
\hline $\begin{array}{l}\text { DER-3D (Dup) } \\
\quad \pm\end{array}$ & $<5.98 \mathrm{E}+01$ & $1.71 \mathrm{E}+03$ & $<5.98 E+01$ & & & $9.80 \mathrm{E}+01$ & $<5.98 \mathrm{E}+01$ & $\begin{array}{l}3.47 \mathrm{E}+02 \\
1.14 \mathrm{E}+02\end{array}$ \\
\hline $\begin{array}{l}\text { DER-3E } \\
\quad \pm\end{array}$ & $<5.85 \mathrm{E}+01$ & $2.22 \mathrm{E}+03$ & $<5.85 \mathrm{E}+01$ & & & $\begin{array}{l}4.68 E+01 \\
2.11 E+02\end{array}$ & $<5.85 \mathrm{E}+01$ & $\begin{array}{l}2.20 \mathrm{E}+04 \\
7.84 \mathrm{E}+03\end{array}$ \\
\hline $\begin{array}{c}\text { DER-3Z } \\
\pm\end{array}$ & $8.06 \mathrm{E}+01$ & $2.65 \mathrm{E}+03$ & $8.06 \mathrm{E}+01$ & & & $<8.06 \mathrm{E}+01$ & $<8.06 \mathrm{E}+01$ & $\begin{array}{l}5.32 E+02 \\
8.39 E+02\end{array}$ \\
\hline \multicolumn{9}{|c|}{ Burnable Poison Rod Assenbly (BPRA) } \\
\hline $\begin{array}{l}\text { DER-4 outer } \\
\quad \pm\end{array}$ & $<1.34 \mathrm{E}+01$ & $9.20 \mathrm{E}+02$ & $1.34 \mathrm{E}+01$ & & & $8.86 \mathrm{E}+01$ & $<1.34 \mathrm{E}+01$ & $\begin{array}{l}6.43 E+01 \\
2.33 E+02\end{array}$ \\
\hline $\begin{array}{l}\text { DER-6 outer } \\
\pm\end{array}$ & $9.96 \mathrm{E}+00$ & $1.20 \mathrm{E}+03$ & $\begin{array}{l}1.07 E+04 \\
5.98 E+03\end{array}$ & & & $\begin{array}{l}1.29 E+01 \\
6.08 E+01\end{array}$ & $<9.96 \mathrm{E}+00$ & $<9.96 \mathrm{E}+00$ \\
\hline DER-6 inner & $7.55 \mathrm{E}+01$ & $1.77 \mathrm{E}+03$ & $1.00 \mathrm{E}+05$ & & & $\begin{array}{l}2.79 E+02 \\
1.13 E+02\end{array}$ & $-7.55 \mathrm{E}+01$ & $<7.55 \mathrm{E}+01$ \\
\hline \multicolumn{9}{|c|}{ Reactor Rod Cluster Control Assembly (RCCA) } \\
\hline $\begin{array}{c}\text { DER-7 ss } \\
?\end{array}$ & $9.92 \mathrm{E}+00$ & $2.67 E+03$ & $\begin{array}{l}6.40 \mathrm{E}+03 \\
1.98 \mathrm{E}+03\end{array}$ & & & $7.12 \mathrm{E}+01$ & $<9.92 \mathrm{E}+00$ & $\begin{array}{l}1.59 E+01 \\
7.24 E+01\end{array}$ \\
\hline $\begin{array}{c}\text { DER-9 ss } \\
\pm\end{array}$ & $<1.53 \mathrm{E}+01$ & $2.42 \mathrm{E}+03$ & $\begin{array}{l}2.95 E+04 \\
9.79 E+03\end{array}$ & & & $\begin{array}{l}1.06 \mathrm{E}+02 \\
3.36 \mathrm{E}+01\end{array}$ & $<1.53 \mathrm{E}+01$ & $\begin{array}{l}1.83 E+02 \\
8.56 E+01\end{array}$ \\
\hline $\begin{array}{l}\text { DER-7 Ag } \\
\quad \pm\end{array}$ & $<.55 \mathrm{E}+00$ & $\begin{array}{l}1.55 \mathrm{E}+00 \\
4.04 \mathrm{E}+00\end{array}$ & $9.28 \mathrm{E}+05$ & $5.30 \mathrm{E}+04$ & $1.62 \mathrm{E}+05$ & $2.07 \mathrm{E}+01$ & $<1.55 \mathrm{E}+00$ & $4.56 \mathrm{E}+01$ \\
\hline $\begin{array}{l}\text { DER-9 Ag } \\
\quad \pm\end{array}$ & $<2.16 \mathrm{E}+00$ & $\begin{array}{l}2.07 \mathrm{E}+01 \\
9.71 \mathrm{E}+00\end{array}$ & $8.37 \mathrm{E}+05$ & $5.35 E+04$ & $1.62 \mathrm{E}+05$ & $\begin{array}{l}1.60 \mathrm{E}+01 \\
5.18 \mathrm{E}+00\end{array}$ & $<2.16 \mathrm{E}+00$ & $2.33 E+01$ \\
\hline DER-9 Ag(Dun) & $\leq 2.16 \mathrm{E}+00$ & $\leq 2.16 \mathrm{E}+01$ & $8.20 \mathrm{E}+05$ & $5.67 \mathrm{E}+04$ & $164 \mathrm{E}+05$ & $1.56 \mathrm{E}+01$ & $\angle 2.16 \mathrm{E}+00$ & $3.97 E+01$ \\
\hline
\end{tabular}


Table 4.7 Selected Major, Minor, and Trace Elements in Boron Carbide and Borosilicate Glass Samples

Concentration in $\mathrm{ug} / \mathrm{g}$

\begin{tabular}{|c|c|c|c|c|c|c|c|c|c|c|}
\hline Sample ID & $\mathrm{Li}$ & $\mathrm{Be}$ & $\mathrm{B}$ & $\mathrm{Na}$ & $\mathrm{Al}$ & Mn & Co & $\mathrm{Ba}$ & $\mathrm{Eu}$ & Sm \\
\hline \multicolumn{11}{|c|}{ Cruciform Control Rod Blade (CRB) - Boron Carbide } \\
\hline DER-IBC & & & & & $\begin{array}{l}7.27 \mathrm{E}+02 \\
1.85 \mathrm{E}+02\end{array}$ & $\begin{array}{l}7.13 E+00 \\
5.96 E+00\end{array}$ & $3.02 \mathrm{E}+04$ & $\begin{array}{l}7.29 E+00 \\
5.03 E+00\end{array}$ & $\begin{array}{l}<1 \\
<1\end{array}$ & $\begin{array}{l}<1 \\
<1\end{array}$ \\
\hline \multicolumn{3}{|l|}{ DER-2BC } & & & $1.15 \mathrm{E}+03$ & $6.06 \mathrm{E}+01$ & $2.98 \mathrm{E}+04$ & $1.70 \mathrm{E}+01$ & $<1$ & 1.5 \\
\hline \multicolumn{11}{|l|}{ DER-3BC } \\
\hline \multicolumn{11}{|c|}{ Burnable Poison Rod Assembly (BPRA) - Borosilicate Glass } \\
\hline DER $4 \mathrm{G}$ & $7.57 \mathrm{E}+03$ & 1 & $3.83 \mathrm{E}+04$ & $3.28 \mathrm{E}+04$ & $1.60 \mathrm{E}+04$ & $4.26 \mathrm{E}+00$ & $<\mathbf{l}$ & $1.31 \mathrm{E}+01$ & $<1$ & $<1$ \\
\hline \pm & $1.08 \mathrm{E}+03$ & & & & & $9.57 \mathrm{E}-01$ & & & & \\
\hline DER-5G & $9.20 \mathrm{E}+03$ & $2.53 E+00$ & $4.72 E+04$ & $2.15 E+04$ & $3.81 E+04$ & $1.11 E+01$ & $1.20 \mathrm{E}+00$ & $1.63 E+01$ & $<1$ & $<1$ \\
\hline \pm & & $1.04 E+00$ & & & & & $4.00 \mathrm{E}-01$ & & & \\
\hline \multicolumn{11}{|l|}{ DER-6G } \\
\hline & $1.15 E+04$ & $9.22 \mathrm{E}+00$ & $3.52 E+04$ & $1.62 E+04$ & $3.49 \mathrm{E}+04$ & $0.00 \mathrm{E}+00$ & $<1$ & $2.11 \mathrm{E}+01$ & $<1$ & $<1$ \\
\hline \pm & & $1.50 \mathrm{E}+01$ & & & & & & & & \\
\hline
\end{tabular}


Table 4.8 Comparison of Our Data to Reported Data* for the Metal Cladding on the Control Rod Assemblies Activity in $\mathrm{Ci} / \mathrm{g}$

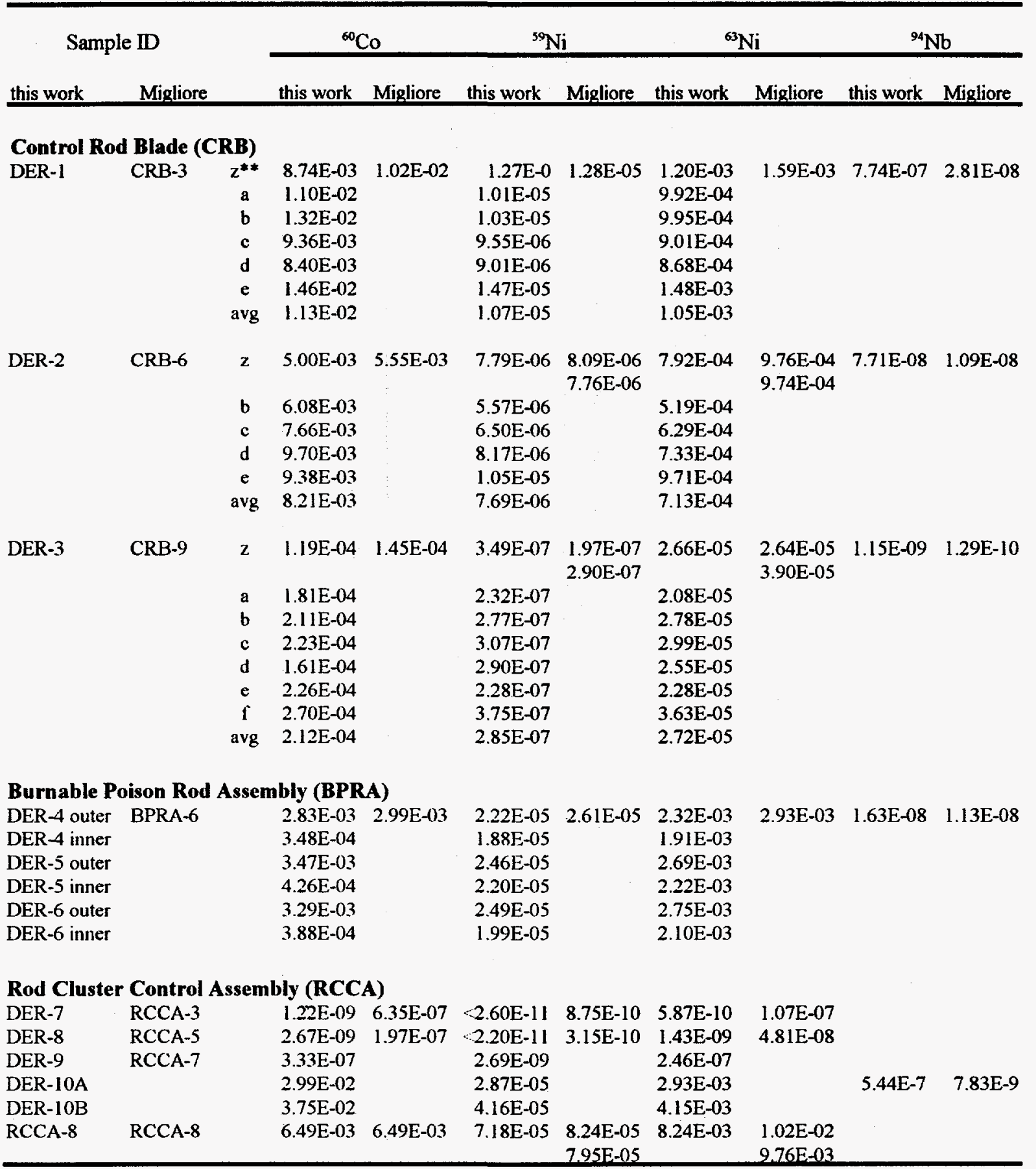

*Reported data is that of Migliore et al., 1994.

**" $\mathrm{z}$ " stands for metal cladding which is what Migliore et al analyzed. Samples a-f are the stainless steel tubes that were contained within the metal cladding. 
In general there was excellent agreement between the results we reported and those reported by Migliore et al. (1994), with agreement being in the range of $1 \%$ to $25 \%$, except for ${ }^{94} \mathrm{Nb}$ where our overall results average about 23 times higher. For example, the control rod blade activity data show excellent agreement between the two sets of results, except for the ${ }^{94} \mathrm{Nb}$ where our results averaged about 14 times higher. Migliore et al. (1994), only analyzed the cladding that surrounded the stainless steel tubes that were within the CRB, and this corresponds to sample " $\mathrm{z}$ " that we reported. In addition, we also have data for a number of stainless steel tubes that were within the CRB and these are samples labeled " $a$ " through " $\mathrm{f}$ " (four to six tubes were sampled). These data are also presented in Table 4.8.

There was only one sample for comparison of results for the BPRA. Our sample DER-5-outer corresponds to the reported data for sample BPRA-6. Again, there is excellent agreement for all radionuclides, including ${ }^{94} \mathrm{Nb}$.

However, there was disagreement in the values observed in the RCCA specimens sampled from the low activity end of the rod. It is believed that this difference was due to the fact that we took great care in conducting numerous dcontaminating and cleaning steps for our samples prior to analysis, while it appears that there was still some fission and activation product contamination derived from the hot cell environment where the samples were prepared. For the one sample with high activity (RCCA-8), there was excellent agreement between the results, but at the low activity end of the RCCA our ${ }^{60} \mathrm{Co}$ and ${ }^{63} \mathrm{Ni}$ values were 200 to 500 times lower than those reported by Migliori, et al. (1994), indicating contamination of their samples. 


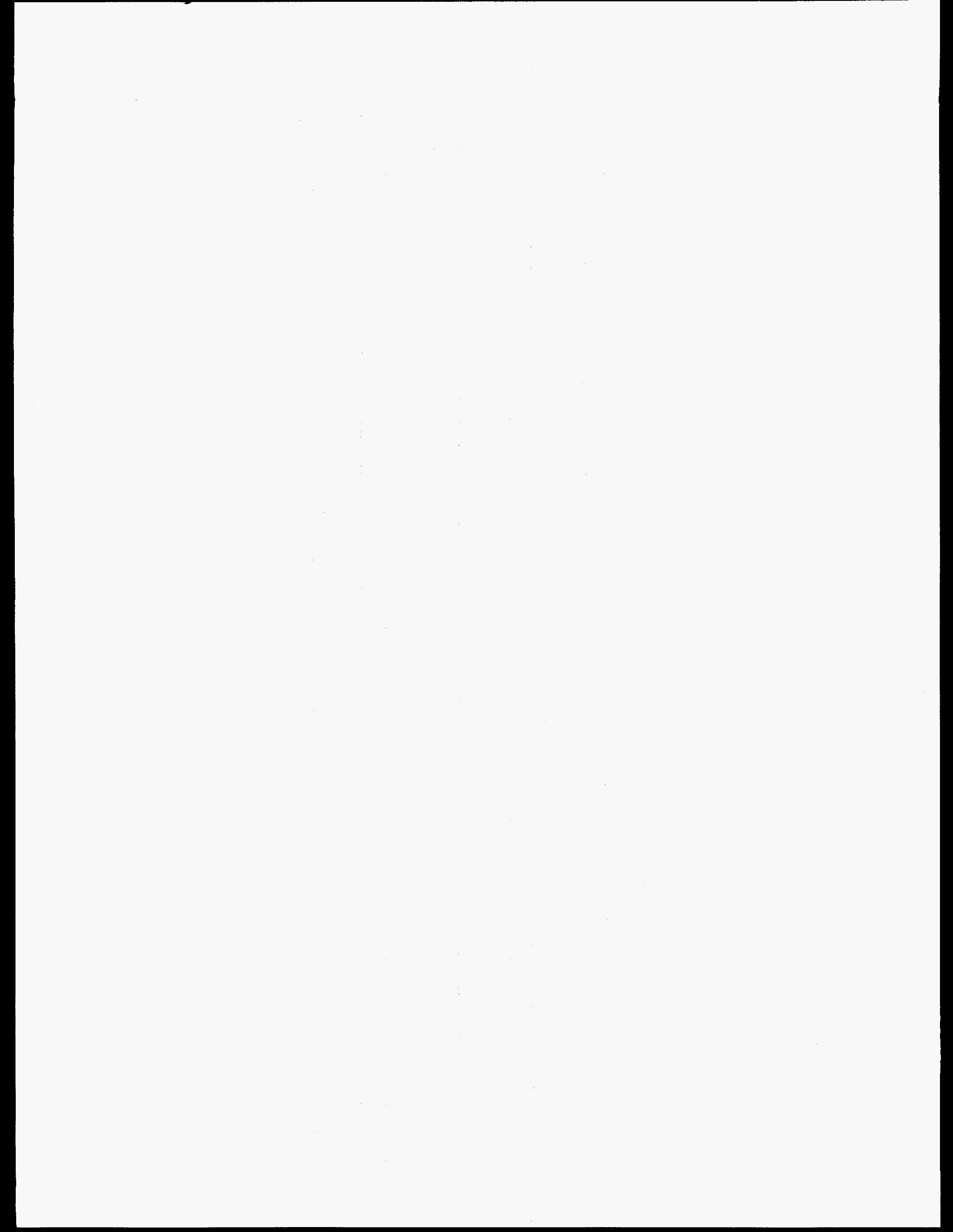




\section{Comparison of Empirical versus Calculated Radionuclide Inventories}

\subsection{Calculation of Curie Content from Empirical Results}

Following the empirical determination of the radionuclides present in the control rods, calculations were performed to determine the total Curie content of each type of control rod assembly.

An example illustrating the calculation of total Curie content for the Control Rod Blade follows. The length of the control rod of interest is 143 in. Each control rod contains 84 tubes with a diameter of 0.138 in and wall thickness of 0.025 in. The density of type 304 stainless steel is $8.0 \mathrm{~g} / \mathrm{cm}^{3}$. The total mass of each rod was calculated to be $240 \mathrm{~g}$ or $20.2 \mathrm{~kg}$ for the 84 rods in the assembly.

Experimentally, samples were taken from three locations along the length of the CRB. These are noted on the schematic of the CRB (Figure 2.1). If this was the only data available, the $C R B$ would be divided into three segments and the Curie content calculated for each segment based on the measured data. However, it was possible to calculate a finer grid using the data obtained from the TLD measurements taken for the direct assay measurements described in Section 3 . It should be noted that this process must be performed for each material found and analyzed in the CRB. Thus, calculations were performed for the stainless steel outer cladding, the inner cylindrical stainless steel tubes containing the boron carbide, and the boron carbide contained within the cylindrical tubes to obtain the total Curie content of the CRB.

The ${ }^{60} \mathrm{Co}$ activity determined for each TLD was tabulated for each location along the control rod. Then the measured activity at the three known locations was ratioed to the corresponding TLD ${ }^{60} \mathrm{Co}$ data and the ${ }^{60} \mathrm{Co}$ activities were interpolated for other TLD measurement locations. $\mathrm{A}^{60} \mathrm{Co}$ activity was then obtained for each of the TLD measurement locations along the $\mathrm{CRB}$. Then, assuming that each segment was $20 \mathrm{~g}$, the ${ }^{60} \mathrm{Co}$ activity per segment per tube was calculated. This value was then multiplied by 84 to get the total activity for all of the stainless steel rods and was determined to be $122.9 \mathrm{Ci}$ as of June $1,1993$.

A similar calculation was performed for the stainless steel that acted as a cladding sheath around the cylindrical rods. Documentation of the CRB assembly indicated that it weighed 218 pounds or $98.9 \mathrm{~kg}$. The weight of the $\mathrm{B}_{4} \mathrm{C}$ contained within the tubes was calculated to be $5.18 \mathrm{~kg}$ (density of $\mathrm{B}_{4} \mathrm{C}$ is $1.76 \mathrm{~g} / \mathrm{cm}^{3}$ ), and the tubes themselves weighed $20.2 \mathrm{~kg}$. Assuming the remaining weight is due to the stainless steel sheath, the weight of the sheath was 73.5 $\mathrm{kg}$.

Again, using the TLD data and our measured activity data, the activity of ${ }^{60} \mathrm{Co}$ was interpolated between the measured locations. Using the process described above, the total ${ }^{60} \mathrm{Co}$ activity was calculated to be $159.5 \mathrm{Ci}$ for the sheath.

A similar calculation was also performed for the $\mathrm{B}_{4} \mathrm{C}$ powder that was collected. The activity of ${ }^{\circ 0} \mathrm{Co}$ contained in the $\mathrm{B}_{4} \mathrm{C}$ within the 84 rods was calculated to be $0.024 \mathrm{Ci}$.

The total calculated ${ }^{60} \mathrm{Co}$ activity as of June 1,1993 was 282.4 Ci for the entire Control Rod Blade, excluding the top stellite section and the botttom velocity limiter.

Similar calculations were made for the Burnable Poison Rod Assembly (BPRA) which yielded a ${ }^{60} \mathrm{Co}$ Curie content of $20 \mathrm{Ci}$. Similar calculations were also made for the reactor Rod Cluster Control Assembly (RCCA). A value of ${ }^{60} \mathrm{Co}$ was calculated but it was also necessary to calculate the activities of ${ }^{110 \mathrm{~m}} \mathrm{Ag}$ and ${ }^{108 \mathrm{~m}} \mathrm{Ag}$. The assumption was made that the $\mathrm{Ag}$ isotopes correlate with the ${ }^{60} \mathrm{Co}$ activity so that the TLD data could be used in the calculations. The calculated concentrations were 7.3 Curies of ${ }^{60} \mathrm{Co}, 10.8 \mathrm{Ci}$ of ${ }^{108 \mathrm{~m}} \mathrm{Ag}$, and 1.1 Ci of ${ }^{110 \mathrm{~m}} \mathrm{Ag}$ as of June 1, 1993.

Table 5.1 shows the Curie content results obtained from our empirical data compared to the Curie contents obtained by the two direct-assay methods. The activity of the BWR CRB and the PWR BPRA was dominated by ${ }^{60} \mathrm{Co}$. The agreement observed for the BWR CRB between the empirically measured values and the results for the two direct-assay methods is quite good; 282 Curies empirically measured versus 246 Curies (Integral Dose Method) or 187 Curies (MCNP Method) by the direct-assay techniques. The agreement for the PWR BPRA empirical (20 Curies) versus direct-assay measurement (22 Curies for Integral Dose or 23 Curies for the MCNP method) was remarkably good. This good agreement lends confidence to the direct-assay methodology used to nondestructively determine the Curie contents of highly radioactive metal-waste components.

The calculation of the total Curie content of the RCCA was a bit more difficult since the activity was not dominated by just the ${ }^{60} \mathrm{Co}$, but also significant concentrations of ${ }^{108 \mathrm{~m}} \mathrm{Ag}$ and ${ }^{110 m} \mathrm{Ag}$ needed to be calculated. In addition, there was a very sharp gradient in activity at the tip of the control rod as observed in the activity data for sample DER-9 and DER$10 \mathrm{~A}$ and $\mathrm{B}$. The total Curie conent of gamma-emitting radionuclides of this control rod as of June 1, 1993 
Table 5.1 Comparison of Radionuclide Contents in Spent Control Rods by Direct Assay and Samplinq/Analysis Methods (Inventories in Curies)*

\begin{tabular}{|c|c|c|c|c|c|}
\hline \multirow[t]{2}{*}{ Method } & \multirow{2}{*}{$\begin{array}{l}\text { BWR Cruciform } \\
\text { Control Rod Blade } \\
{ }^{60} \mathrm{Co}\end{array}$} & \multirow{2}{*}{$\begin{array}{l}\text { PWR Burnable Poison } \\
\text { Control Rod } \\
{ }^{60} \mathrm{Co}\end{array}$} & \multicolumn{3}{|c|}{$\begin{array}{c}\text { PWR Rod Cluster Control } \\
\text { Assembly }\end{array}$} \\
\hline & & & ${ }^{60} \mathrm{Co}$ & ${ }^{108 m} \mathrm{Ag}$ & ${ }^{110 \mathrm{~m}} \mathrm{Ag}$ \\
\hline Empirical & 282 & 20 & 7.3 & 10.8 & 1.1 \\
\hline \multicolumn{6}{|l|}{ Direct Assay } \\
\hline ---Integral dose & 246 & 22 & 2.6 & 10.6 & 0.4 \\
\hline ---MCNP Method & 187 & 23 & 2.3 & 9.4 & 0.4 \\
\hline
\end{tabular}

*Activities decay corrected to June I, 1993.

calculated from the empirical data, yielded a value of 19.2 Curies ( $7.3 \mathrm{Ci}^{60} \mathrm{Co}, 10.8 \mathrm{Ci}^{108 \mathrm{~m}} \mathrm{Ag}$, and $1.1 \mathrm{Ci}^{110 \mathrm{~m}} \mathrm{Ag}$ ) versus $13.6 \mathrm{Ci}\left(2.6 \mathrm{Ci}{ }^{60} \mathrm{Co}, 10.6 \mathrm{Ci}{ }^{108 \mathrm{~m}} \mathrm{Ag}\right.$, and $0.4 \mathrm{Ci}$ ${ }^{110 \mathrm{~m}} \mathrm{Ag}$ ) for the direct assay Integral Dose Method, or 12.1 $\mathrm{Ci}\left(2.3 \mathrm{Ci}{ }^{60} \mathrm{Co}, 9.4 \mathrm{Ci}^{108 \mathrm{~m}} \mathrm{Ag}\right.$, and $\left.0.4 \mathrm{Ci}^{110 \mathrm{~m}} \mathrm{Ag}\right)$ for the direct-assay MCNP Method.

\subsection{Comparison of Empirical vs. Calculated Radionuclide Concentrations in Control Rods}

The empirically determined Curie content from this work and Migliore et al. (1994) has been tabulated for ${ }^{60} \mathrm{Co},{ }^{59} \mathrm{Ni}$, ${ }^{63} \mathrm{Ni}$, and ${ }^{94} \mathrm{Nb}$ in Tables 5.2, 5.3, 5.4, and 5.5. In addition to the empirical results, the Tables also include the results obtained by Migliore et al. (1994) when using predictive methodologies such as ORIGEN2 and MCNP. Since the dominant radionuclide activities observed in the control rods was from the type 304 stainless steel used for the cladding and tubing of these control rods, the results of Migliore et al. (1994) for the Curie contents are consistent with our results, with one exception. The contribution of the Ag from the Ag-In-Cd absorber needs to be considered when one is calculating the Curie contents of the RCCA. Since ${ }^{108 m} \mathrm{Ag}$ has a half-life of 130 years, it will become the dominant dose-contributing radionuclide for hundreds of years in this type of control rod assembly.

Our empirical data in Tables 5.2, 5.3, 5.4, and 5.5 has been converted from activity per gram of metal to activity per cubic meter of metal to enable the comparison to the ORIGEN2 and MCNP results which were reported in $\mathrm{Ci} / \mathrm{m}^{3}$ of metal in Migliore et al. (1994). The conversion factor was the density of type 304 stainless steel, $8.00 \mathrm{~g} / \mathrm{cm}^{3}$. As noted earlier, there was good agreement between our experimental results and that presented by Migliore et al. (1994) for the stainless steel samples. The ORIGEN2 results for the CRB was generally lower than the expermental values except for the bottom 1/4 where the calculated results were higher. The BPRA comparison showed an ORIGEN result that was 1.5-2 times the empirically determined value. The RCCA comparison showed that the ORIGEN2 results were about 4 times lower compared to the empirical measurements.

Our empirical results can be compared to the MCNP results for the BPRA sample 6. The MCNP result was lower than the empirical data by about a factor of 3.5. The empirical results for the RCCA samples were also compared to the MCNP result. The MCNP result was low compared to the laboratory results by a factor of 3.6 . 
Table 5.2 Comparison of Empirical and Calculated Curie Contents for ${ }^{60} \mathrm{Co}$

\begin{tabular}{|c|c|c|c|c|c|c|c|}
\hline \multicolumn{8}{|c|}{ Activity in $\mathrm{Ci} / \mathrm{m}^{3}$} \\
\hline & & \multicolumn{6}{|c|}{ Migliore et al. (1994) } \\
\hline \multicolumn{2}{|c|}{ This work } & \multicolumn{2}{|c|}{ Laboratory Results } & \multicolumn{2}{|c|}{ ORIGEN2 - Calculated } & \multicolumn{2}{|c|}{ MCNP - Calculated } \\
\hline Sample ID & Activity & Sample ID & Activity & Sample ID & Activity & Sample ID & Activity \\
\hline & & \multicolumn{4}{|c|}{ Control Rod Blade Assembly (CRB) } & & \\
\hline DER-1 (z) & $7.00 \mathrm{E}+04$ & $\mathrm{C}-3$ & $8.16 \mathrm{E}+04$ & CRB Top 1/4 & $1.95 E+04$ & & \\
\hline DER-2(z) & $4.00 \mathrm{E}+04$ & $\mathrm{C}-6$ & $4.44 \mathrm{E}+04$ & CRB 3rd 1/4 & $1.61 \mathrm{E}+04$ & & \\
\hline \multirow[t]{3}{*}{ DER-3(z) } & $9.52 E+02$ & C-9 & $1.16 \mathrm{E}+03$ & CRB Bottom $1 / 4$ & $5.97 \mathrm{E}+03$ & & \\
\hline & & C-9 (duplicate) & $1.11 \mathrm{E}+03$ & & & & \\
\hline & & \multicolumn{4}{|c|}{ Burnable Poison Rod Assembly (BPRA) } & & \\
\hline \multirow[t]{2}{*}{ DER-5 outer } & $2.78 \mathrm{E}+04$ & BPRA-6 & $2.39 \mathrm{E}+04$ & BPRA-6 & $4.00 E+04$ & BPRA-6 & $7.06 \mathrm{E}+03$ \\
\hline & & \multicolumn{4}{|c|}{ Reactor Rod Cluster Control Assembly (RCCA) } & & \\
\hline DER-7 ss & $9.76 \mathrm{E}-03$ & RCCA-3 & $5.08 \mathrm{E}+00$ & RCCA & $5.84 \mathrm{E}+05$ & & \\
\hline DER-8 ss & $2.14 \mathrm{E}-02$ & RCCA-5 & $1.58 \mathrm{E}+00$ & & & & \\
\hline DER-9 ss & $2.66 \mathrm{E}+00$ & $\mathrm{RCCA}-7$ & & & & & \\
\hline RCCA-8 & $5.19 E+04$ & RCCA-8 & $5.19 \mathrm{E}+04$ & & & $\mathrm{RCCA}-8$ & $1.43 E+04$ \\
\hline
\end{tabular}

Table 5.3 Comparison of Empirical and Calculated Curie Contents for ${ }^{59} \mathrm{Ni}$

\begin{tabular}{|c|c|c|c|c|c|c|c|}
\hline \multicolumn{8}{|c|}{ Activity in $\mathrm{Ci} / \mathrm{m}^{3}$} \\
\hline & & \multicolumn{6}{|c|}{ Migliore et al } \\
\hline \multicolumn{2}{|c|}{ This work } & \multicolumn{2}{|c|}{ Laboratory Results } & \multicolumn{2}{|c|}{ ORIGEN2 - Calculated } & \multicolumn{2}{|c|}{ MCNP - Calculated } \\
\hline Sample ID & Activity & Sample ID & Activity & Sample ID & Results & Sample ID & Results \\
\hline \multicolumn{8}{|c|}{ Control Rod Blade Assembly (CRB) } \\
\hline DER-1(z) & $1.02 \mathrm{E}+02$ & $\mathrm{C}-3$ & $1.02 \mathrm{E}+02$ & CRB Top 1/4 & $1.79 E+01$ & & \\
\hline DER-2(z) & $6.23 \mathrm{E}+01$ & C-6 & $6.47 \mathrm{E}+01$ & CRB 3rd I/4 & $1.35 \mathrm{E}+01$ & & \\
\hline & & C-6 (duplicate) & $6.21 \mathrm{E}+01$ & & & & \\
\hline DER-3(z) & 2.79 & C-9 & $1.58 \mathrm{E}+00$ & CRB Bottom $1 / 4$ & 4.08 & & \\
\hline & & C-9 (duplicate) & $2.32 \mathrm{E}+00$ & & & & \\
\hline \multicolumn{8}{|c|}{ Burnable Poison Rod Assembly (BPRA) } \\
\hline DER-5 outer & $1.97 E+02$ & BPRA-6 & $2.09 \mathrm{E}+02$ & BPRA- 6 & $2.51 \mathrm{E}+02$ & BPRA-6 & $2.27 \mathrm{E}+01$ \\
\hline \multicolumn{8}{|c|}{ Reactor Rod Cluster Control Assembly (RCCA) } \\
\hline DER-7 ss & $<2.1 \mathrm{E}-04$ & RCCA-3 & $7.00 \mathrm{E}-03$ & $\mathrm{RCCA}$ & $1.18 \mathrm{E}+03$ & & \\
\hline DER-8 ss & $<1.8 \mathrm{E}-04$ & RCCA-5 & $2.52 \mathrm{E}-03$ & & & & \\
\hline DER-9 ss & $2.15 \mathrm{E}-02$ & RCCA-7 & & & & & \\
\hline RCCA-8 & $5.74 \mathrm{E}+02$ & RCCA-8 & $6.59 \mathrm{E}+02$ & & & RCCA -8 & 4.52E+01 \\
\hline
\end{tabular}


Table 5.4 Comparison of Empirical and Calculated Curie Contents for ${ }^{63} \mathrm{Ni}$

Activity in $\mathrm{Ci} / \mathrm{m}^{3}$

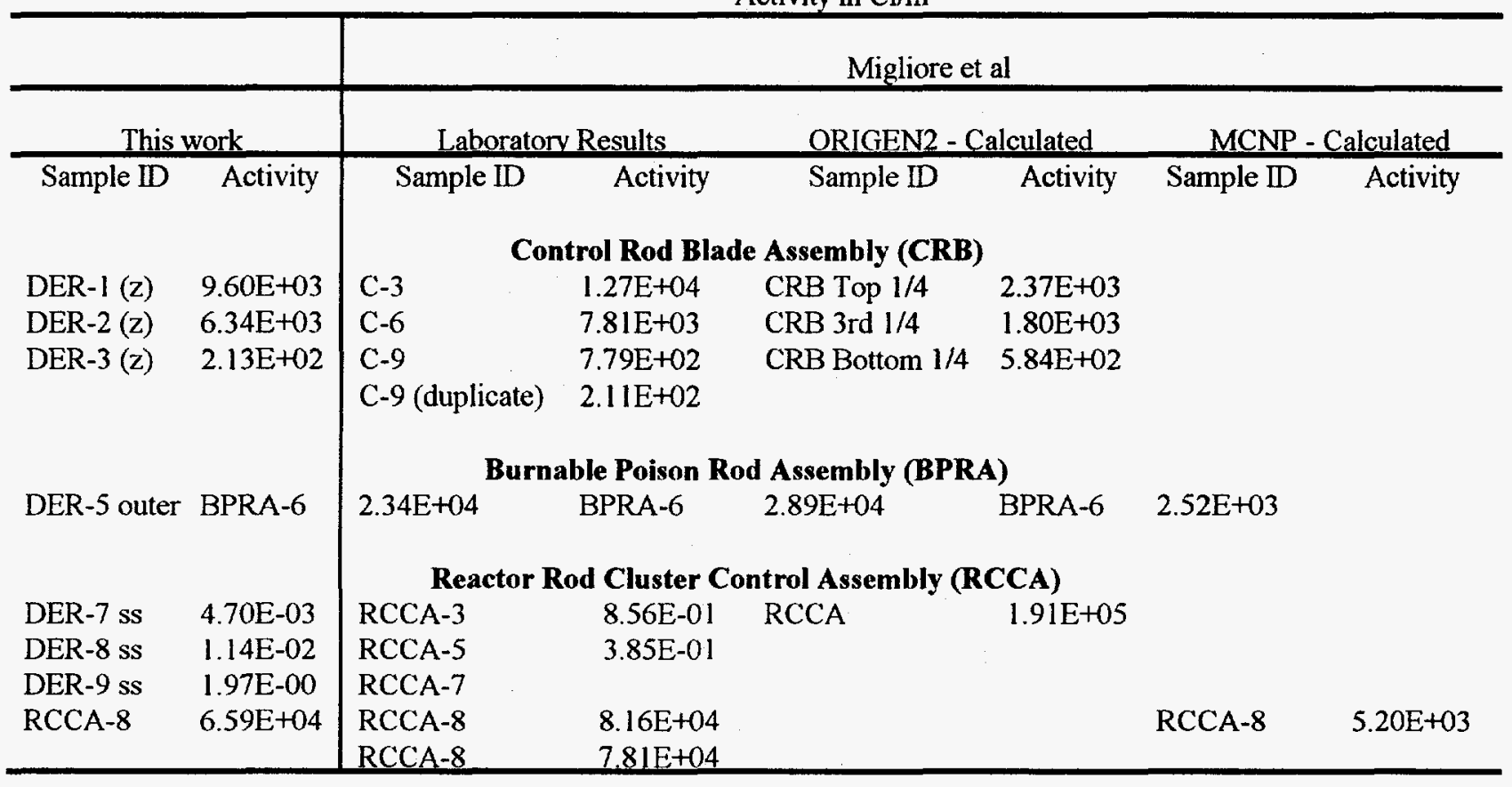

Table 5.5 Comparison of Empirical and Calculated Curie Contents for ${ }^{94} \mathrm{Nb}$.

\begin{tabular}{|c|c|c|c|c|c|c|c|}
\hline \multicolumn{8}{|c|}{ Activity in $\mathrm{Ci} / \mathrm{m}^{3}$} \\
\hline & & \multicolumn{6}{|c|}{ Migliore et al } \\
\hline \multicolumn{2}{|c|}{ This work } & \multicolumn{2}{|c|}{ Laboratory Results } & \multicolumn{2}{|c|}{ ORIGEN2 - Calculated } & \multicolumn{2}{|c|}{ MCNP - Calculated } \\
\hline Sample ID & Activity & Sample ID & Activity & Sample ID & Activity & Sample ID & Activity \\
\hline \multicolumn{8}{|c|}{ Control Rod Blade Assembly (CRB) } \\
\hline DER-1(c) & $6.20 \mathrm{E}-00$ & $\mathrm{C}-3$ & $2.25 \mathrm{E}-01$ & CRB Top $1 / 4$ & $6.59 \mathrm{E}-02$ & & \\
\hline DER-2(c) & $6.20 \mathrm{E}-01$ & C- 6 & $8.72 \mathrm{E}-02$ & CRB 3rd $1 / 4$ & 4.97E-02 & & \\
\hline DER-3(c) & $9.20 \mathrm{E}-03$ & C-9 & $1.03 E-03$ & CRB Bottom $1 / 4$ & $1.50 \mathrm{E}-02$ & & \\
\hline & & C-9 (duplicate) & 2.30E-03 & & & & \\
\hline \multicolumn{8}{|c|}{ Burnable Poison Rod Assembly (BPRA) } \\
\hline DER-4 outer & $1.30 \mathrm{E}-01$ & BPRA-6 & $9.04 \mathrm{E}-02$ & BPRA-6 & 4.14E-01 & BPRA-6 & 4.53E-02 \\
\hline \multicolumn{8}{|c|}{ Reactor Rod Cluster Control Assembly (RCCA) } \\
\hline DER-10A & 4.35E+00 & $\mathrm{RCCA}-8$ & $6.26 \mathrm{E}-02$ & $\mathrm{RCCA}$ & $9.98 \mathrm{E}-01$ & $\mathrm{RCCA}-8$ & $1.46 \mathrm{E}-02$ \\
\hline
\end{tabular}




\section{Radioactive Waste Disposal Considerations}

The report by Migliore et al. (1994) has provided a very detailed analysis of these three spent control rod assemblies (or Non-Fuel Assemblies (NFA)) with respect to their classification according to 10 CFR Part 61.55. The report has discussed the use of volume averaging for disposing of these spent control rods. It also notes "...that some NFA components may not need to be classified. Many NFA components, such as the BPRA and RCCA, fit into a fuel assembly. If a host assembly is available, it would likely be most effective to dispose of them together, since spent fuel assemblies are considered high-level waste and will have their own repository. However, there will not always be a host assembly for every NFA component requiring disposal. In addition, many NFA components, such as the CRB, do not fit within an assembly. In these cases, it is necessary to perform the proper classification."

Based on the analysis in the Migliore et al, report, wherein only the cladding (stainless steel) and some other structural pieces were analyzed, each of the spent control rod assemblies has been classified according to 10 CFR Part 61.55. Their conclusions for the BPRA were that the top fourth of the assembly (hold down assembly and thimble plugs) would be considered Greater than Class C (GTCC) and the three equal sections of the poison rods would be Class $\mathrm{C}$ waste. If all four sections were placed in one package, the package would be classified as Class $\mathrm{C}$.

The RCCA was divided into four sections for classification purposes with the top three sections being classified as Class $\mathrm{A}$ (maybe Class B depending on the short-lived nuclides present) and the bottom section classified as Class $\mathrm{C}$. If all four sections were packaged together, the package would be considered Class $\mathrm{C}$.

The CRB, if divided into four sections, would have the top three sections classified as Class $\mathrm{C}$ and the bottom section that included the velocity limiter as Class A (maybe Class B). If the four sections were packaged together, the package would be considered Class $\mathrm{C}$.

Our analytical data, since it agrees very well with that of Migliore et al. (1994) for the cladding on the spent fuel assemblies, would support their conclusions for the waste classifications for the CRB and the BPRA. The activity content of the boron carbide in the CRB and the glass from the BPRA did not contribute significantly to the activity levels of these assemblies.

However, the presence of ${ }^{108 \mathrm{~m}} \mathrm{Ag}$ in the Ag-In-Cd absorber rod of the RCCA was not acknowledged in the Migliore et al report. Our calculations for the neutron absorber portion of the RCCA indicate a total Curie content on June 1, 1993 of 19.2 Curies. The contribution of ${ }^{60} \mathrm{Co}$ was $7.3 \mathrm{Ci}$, that of ${ }^{108 \mathrm{~m}} \mathrm{Ag}$ was $10.8 \mathrm{Ci}$, and that of ${ }^{110 \mathrm{~m}} \mathrm{Ag}$ was $1.1 \mathrm{Ci}$. Therefore, the dominant activity on June 1, 1993 was due to the ${ }^{108 \mathrm{~m}} \mathrm{Ag}$. Since the ${ }^{108 \mathrm{~m}} \mathrm{Ag}$ has a $130 \mathrm{yr}$ half-life, it will also be the dominant activity even after 100 years of decay. The only other isotope that was measured that would be present in significant quantities after 100 years of decay is ${ }^{63} \mathrm{Ni}$. Since the activity of ${ }^{63} \mathrm{Ni}$ in pCi/g is a factor of 10 less than that of ${ }^{108 \mathrm{~m}} \mathrm{Ag}$, one predicts that the ${ }^{108 \mathrm{~m}} \mathrm{Ag}$ will be the dominant activity with time. Figure 6.1 illustrates the change in activity with time for these four isotopes. The absolute values of ${ }^{60} \mathrm{Co},{ }^{108 \mathrm{~m}} \mathrm{Ag}$, and ${ }^{110 \mathrm{~m}} \mathrm{Ag}$ were those calculated from the empirical data at the time of the removal of the assembly from the reactor core. For ${ }^{63} \mathrm{Ni}$, a value of 1 was chosen because the empirically determined values of ${ }^{63} \mathrm{Ni}$ were about a factor of 10 lower than the determined values for ${ }^{108 \mathrm{~m}} \mathrm{Ag}$.

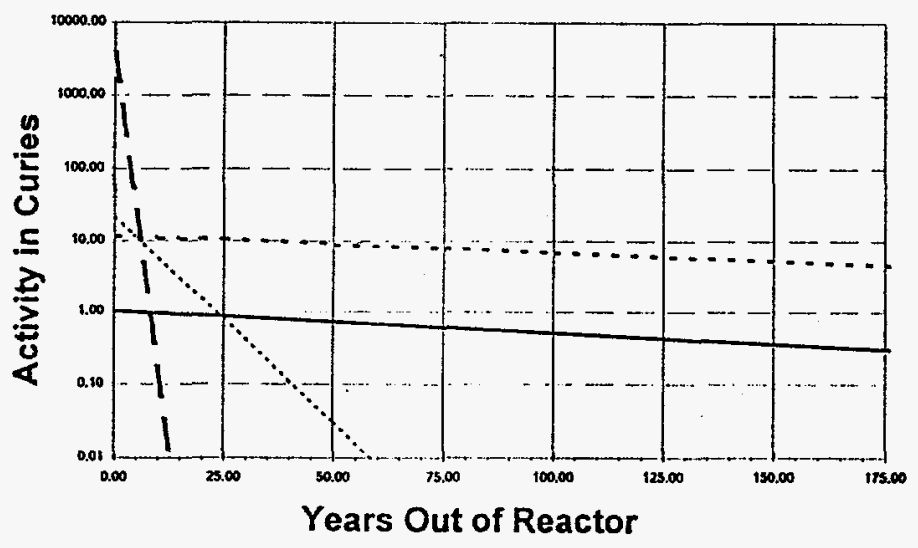

$\ldots \ldots \mathrm{Co}-60--\mathrm{Ag}-10 \mathrm{Bm}-\mathrm{Ag}-110 \mathrm{~m}-\mathrm{Ni}-63$

Figure 6.1 Decrease in Concentration with Time for Dominant Isotopes in RCCA 



\section{Summary and Conclusions}

Three different types of control rods were obtained for direct assay measurements and for empirical sampling and analysis. They were: 1) a BWR CRB which consisted of stainlesssteel inner tubes and cladding and a neutron poison consisting of boron carbide, 2) a PWR RCCA which consisted of stainless-steel cladding and Ag-In-Cd neutron absorber rods, and 3) a PWR BPRA which consisted of an inner and outer stainless steel tube housing a borosilicate glass tube which served as a neutron poison. Samples were obtained from at least three locations on each control rod, and the radionuclide contents were determined. In the stainless-steel tubes and cladding, the 1O CFR Part 61.55 radioisotopes ${ }^{60} \mathrm{Co},{ }^{59} \mathrm{Ni},{ }^{63} \mathrm{Ni}$, and ${ }^{94} \mathrm{Nb}$ were determined as well as ${ }^{54} \mathrm{Mn}$, ${ }^{93 \mathrm{~m}} \mathrm{Nb}$, and ${ }^{93} \mathrm{Mo},{ }^{125} \mathrm{Sb},{ }^{134} \mathrm{Cs},{ }^{137} \mathrm{Cs},{ }^{152} \mathrm{Eu}$, ${ }^{154} \mathrm{Eu}$, and ${ }^{135} \mathrm{Eu}$. In addition, the RCCA also contained ${ }^{108 \mathrm{~m}} \mathrm{Ag},{ }^{110 \mathrm{~m}} \mathrm{Ag},{ }^{109} \mathrm{Cd}$, and ${ }^{113 m} \mathrm{Cd}$ in the $\mathrm{Ag}-\mathrm{In}-\mathrm{Cd}$ absorber rod.

Selected samples from each spent control rod assembly were analyzed for their stable element content. The major and minor elements were determined and compared to known compositions for type 304 stainless steel since this was the material used for the cladding and other metal pieces. Our data was consistently high (plus 5\% to $34 \%$ ) in the mass balance that was calculated.

The BWR Control Rod Blade, composed of stainless steelclad boron carbide, contained predominantly ${ }^{60} \mathrm{Co}$, which was produced by neutron activation of the nominally $2800 \mathrm{ppm}$ of stable cobalt present in the steel. Nickel- $63,{ }^{93 \mathrm{~m}} \mathrm{Nb}$, and ${ }^{59} \mathrm{Ni}$ were the next most abundant long-lived activation products, being about 10 -fold, 300 -fold, and 1000-fold lower, respectively, in concentration compared to ${ }^{60} \mathrm{Co}$. The ${ }^{94} \mathrm{Nb}$ concentrations averaged about 50 -fold lower than those for ${ }^{43} \mathrm{~m} \mathrm{Nb}$. The concentrations of the activation products decreased approximately 50 -fold from the insert end to the tail end of the neutron-absorbing section of the CRB. The gamma dose rate at the insertion end of the CRB peaked at about $2900 \mathrm{R} / \mathrm{h}$ at contact in August, 1990 approximately two years after removed from service. The boron carbide neutron absorber material in the CRB contained relatively low concentrations of all radionuclides, and this material contributed insignificantly to the total radionuclide inventory for the CRB.

The PWR Burnable Poison Rod Assembly, composed of stainless steel-clad borosilicate glass, likewise contained predominantly ${ }^{60} \mathrm{Co}$, produced from the $1600 \mathrm{ppm}$ of cobalt present in the steel. This steel likewise contained similiar amounts of ${ }^{63} \mathrm{Ni},{ }^{93 \mathrm{~m}} \mathrm{Nb}$, ${ }^{59} \mathrm{Ni}$, and ${ }^{94} \mathrm{Nb}$, relative to the ${ }^{60} \mathrm{Co}$, as observed in the CRB. The concentrations of the activation products were rather uniformly distributed over the length of the neutron-absorbing section of the BPRA. The gamma dose rate over this section was about $120 \mathrm{R} / \mathrm{h}$ at contact in August, 1990, approximately 15 years after removal from service.

The PWR Rod Cluster Control Assembly is composed of stainless steel-clad rods of an alloy made of $80 \% \mathrm{Ag}, 15 \% \mathrm{In}$, and $5 \% \mathrm{Cd}$ for absorbing neutrons. The radionuclide composition of this assembly is unique, in that the most abundant long-lived radionuclide was ${ }^{108 \mathrm{~m}} \mathrm{Ag}$. Silver- $108 \mathrm{~m}$ has a half-life of 130 years and decays mainly by electron capture accompanied by the emission of three relatively high energy coincident gamma rays $(439,614$, and $722 \mathrm{keV})$ each of $91 \%$ relative intensity. On a per gram basis, the concentration of ${ }^{108 \mathrm{~m}} \mathrm{Ag}$ in this alloy is comparable to the ${ }^{60} \mathrm{Co}$ concentrations in the stainless steel cladding, but the mass of the $\mathrm{Ag} / \mathrm{h} / \mathrm{Cd}$ alloy greatly exceeds that of the stainless steel cladding. Therefore, the ${ }^{108 \mathrm{~m}} \mathrm{Ag}$ will be the dominant gamma dose-contributing radionuclide in this type of control rod assembly for many hundreds of years. Silver- $108 \mathrm{~m}$ is not addressed in 10CFR61, so it cannot be considered in waste classification assessments for this assembly. The RCCA was fully withdrawn at all times during full power operations and only the first few tens of $\mathrm{cm}$ on the insertion end of the RCCA were highly neutron activated. The gamma dose rate at the insertion end peaked at about $290 \mathrm{R} / \mathrm{h}$ at contact in August, 1990, approximately 10 years after removal from service.

It was possible to directly compare radionuclide measurements for several activation products $\left({ }^{60} \mathrm{Co},{ }^{63} \mathrm{Ni}\right.$, ${ }^{59} \mathrm{Ni}$, and ${ }^{94} \mathrm{Nb}$ ) with samples taken from approximately the same locations on the rod assemblies by another group at PNL (Migliori, et al., 1994). The results of this intercomparison were very good, with general agreement being in the range of $1 \%$ to $25 \%$, except for ${ }^{94} \mathrm{Nb}$ where our results averaged about 23 times higher.

Direct assay measurements of the three spent control rod assemblies were conducted in the hot cell facilities at PNL. This technique, which was described in detail in, Robertson, et. al (1993), consists of: 1) direct gamma ray spectrometry to identify those radionuclides contributing to the gamma dose rate, 2) thermoluminescent dosimetry (TLD) to measure the gamma dose rate along the length of the control rod, 3) dose-to-Curie conversion using appropriate shielding/geometry codes, and 4) correlations (scaling) to the ${ }^{60} \mathrm{Co}$ to estimate the concentrations of other 10CFR61 radionuclides in the assemblies. The results of the direct assay measurements were only $10 \%$ lower than the empirical measurements for the CRB and the BPRA. The laboratory value for ${ }^{108 \mathrm{~m}} \mathrm{Ag}$, which was the most abundant radionuclide in the RCCA and contributed to most of the gamma dose, was only $2 \%$ higher than the direct assay results, but the ${ }^{60} \mathrm{Co}$ 
and ${ }^{110 \mathrm{~m}} \mathrm{Ag}$ laboratory values for the RCCA were a factor of 2.8 higher than the direct assay results. This generally good agreement between the laboratory versus the direct assay measurements of the radionuclide contents of spent control rod assemblies lends confidence that the direct assay methodologies can provide very accurate determinations of the radionuclide inventories of spent control rod assemblies and other types of highly neutron-activated metal wastes.

Calculated radionuclide inventories for these spent control rod assemblies were also determined by a reactor physics group at PNL using both ORIGEN2 and MCNP modeling, and their results were compared with our laboratory measurements. Neutronics modeling calculations are especially difficult to perform for spent control rod assemblies because of the large quantities of neutron absorbing materials in the rods and the uncertainties in their exact position relative to the reactor core over their operational history. The objective of this comparison was to determine how accurate the calculations were relative to the laboratory measurements (assumed to be the more accurate of the two methods). This comparison showed that for the $\mathrm{CRB}$ our laboratory values for ${ }^{60} \mathrm{Co},{ }^{63} \mathrm{Ni}$, and ${ }^{59} \mathrm{Ni}$ were about 3 to 5 times higher than the calculated values at the insert ("hot") end of the assembly, and at the "cold" end of the assembly our laboratory values were 0.15 to 0.68 times the calculated values. For the BPRA, our laboratory ${ }^{60} \mathrm{Co}$ values were 3.9 times higher than the calculated values, and the laboratory ${ }^{63} \mathrm{Ni}$ and ${ }^{59} \mathrm{Ni}$ values were 0.78 and 0.73 times the calculated values. For the insert end of the RCCA, our laboratory ${ }^{60} \mathrm{Co},{ }^{63} \mathrm{Ni}$, and ${ }^{59} \mathrm{Ni}$ values were $3.6,12.7$, and 12.6 times higher, respectively, than the calculated values. These comparisons confirm the difficulty in calculating the radionuclide inventories in spent control rod assemblies. It appears that generally it is possible to perform radionuclide inventory calculations that are within a factor of about 5 of the true values, but occasionally, differences exceeding a factor of ten were observed. Obviously, the direct assay techniques are preferable to the calculational methods for estimating radionuclide inventories of spent control rod assemblies.

The radionuclide inventories of the three spent control rod assemblies were assessed to provide a 10CFR6I waste classification of these materials. If concentration averaging over the entire assemblies is performed, as allowed in 10CFR61.55, then each of the assemblies would be classified as Class C low-level waste, even though the "hot" ends of the $\mathrm{CRB}$ and BPRA approached or slightly exceeded the Class $\mathrm{C}$ limit. Nickel-63, followed by ${ }^{94} \mathrm{Nb}$, were the classificationcontrolling radionuclides. Since the concentrations of these radionuclides are so close to the Class $\mathrm{C}$ limit for the these types of activated-metal waste it is important that the determination of their radionuclide contents be determined as accurately as possible.

The information and data bases that have been generated during these radionuclide characterization studies have provided a more comprehensive and reliable assessment of the radiological factors associated with the decommissioning of nuclear reactor power stations. 


\section{References}

10 CFR 61. 1991. U.S. Nuclear Regulatory Commission, "Licensing Requirements for Land Disposal of Radioactive Wastes." U.S. Code of Federal Regulations.

53 FR 24018-56. June 27, 1988. "General Requirements for Decommissioning Nuclear Facilities" Final Rule, 10 CFR Parts 30, 40,50, 51, 70, and 72. Federal Register.

54 FR 22578-27583. May 1989. "Disposal of Radioactive Waste." Final Rule. 10 CFR 61. I.C.

Abel, K H., et al. 1986. Residual Radionuclide Contamination Within and Around Commercial Nuclear Power Plants. NUREG/CR-4289, U.S. Nuclear Regulatory Commission, Washington D.C.

Evans, J. C., E. A. Lepel, R. W. Sanders, C. L. Wilkerson, W. Silker, C. W. Thomas, K. H. Abel, and D. E. Robertson, 1984. Long-Lived Activation Products in Reactor Materials. NUREG/CR-3474. Prepared for the U.S. Nuclear Regulatory Commission by Pacific Northwest Laboratory, Richland, Washington.

Evans, J. C., E. A. Lepel; R. W. Sanders, C. W. Thomas, D. E. Robertson, 1988. "Long-Lived Activation Products in Light-Water Reactor Construction Materials: Implications for Decommissioning." Radioactive Waste Management Nuclear Fuel Cvcle. 11 (1), pp. 1-39.

Hensley, W. K., E. A. Lepel, M. E. Yuly, K. H. Abel. 1988 "Adaptation and Implementation of the RAYGUN Gammaray Analayis Code on the IBM PC." Journal of Radioanalytical and Nuclear Chemistry, 124(2), pp. 481499.

Konzek, G. J., J. D. Ludwick, W. E. Kennedy, and R. I. Smith. 1982. Technology, Safetv, and Costs of Decommissioning Reference Nuclear Research and Test Reactors. NUREG/CR-1756, Vols. I and 2. Prepared for the U.S. Nuclear Commission by Pacific Northwest Laboratory, Richland, Washington.

Lepel, E. A. 1990. "Procedure for Gamma Counting and Data Reduction in the Low-Level Counting Room, 329 Building." PNL-ALO-464. In Analytical Chemistry Laboratory Procedure Compendium. PNL-MA-599, Pacific Northwest Laboratory, Richland, Washington.

Luksic, A. T., et al. 1986. Spent Fuel Disassemblv Hardware and Other Non-Fuel Bearing Components: Characterization, Disposal Cost Estimates, and Proposed Repository Acceptance Requirements. PNL-6046, Pacific Northwest Laboratory. Richland, Washington.
Migliore, R. J., B. D. Reid, S. K. Fadeff, K. A. Fauley, U. P. Jenquin. 1994. Non-Fuel Assembly Components: $10 \mathrm{CFR}$ 61.55 Classification for Waste Disposal. PNL-

10103/UC520. Pacific Northwest Laboratory, Richland, Washington.

Murphy, E. S. and G. M. Holter. 1982. Technology, Safety, and Costs of Decommissioning Reference Light Water Reactors Following Postulated Accidents. NUREG/CR2601, Vols. I and 2. Prepared for the U.S. Nuclear Regulatory Commission by Pacific Northwest Laboratory, Richland. Washington.

Oak, H. D., G. M. Holter, W. E. Kennedy, Jr., and G. J. Konzek. 1980. Technology, Safety, and Costs of Decommissioning a Reference Boiling Water Reactor Power Station. NUREG/CR-0672, Vols. 1 and 2. Prepared for the U.S. Nuclear Regulatory Commission by Pacific Northwest Laboratory, Richland, Washington.

Rohertson, D. E., C. W. Thomas, N. L. Wynhoff, and D. L. Haggard. 1993. Radionuclide Characterization of Reactor Decommissioning Waste and Neutron Activated Metals.NUREG/DR5894, PNL-8106, U. S. Nuclear Regulatory Commission, Washington, D.C.

Robertson, D. E., C. W. Thomas, N. L. Wynhoff, and D. C. Hetzer. 1991. Radionuclide Characterization of Reactor Decommissioning Waste and Spent Fuel Assemblv Hardware. NUREG/CR-5343,PNL-6806, U.S. Nuclear Regulatory Commission, Washington D.C.

Robertson, D. E., C. W. Thomas, N. L. Wynhoff, and D. C. Hetzer. 1990. "Characterization of Long-Lived Activation Products in Spent Fuel Assembly Hardware and Reactor Pressure Vessel Steel." Nuclear Engineering Design. 118, pp. 463-486

Robertson, D. E., et al. 1984. Residual Radionuclide Contamination Within and Around Nuclear Power Plants: Origin, Distribution, Inventory, and Decommissioning Assessment." Radioactive Waste Management Nuclear Fuel Cycle 5, pp. 285-310.

Smith, R. I, G. J. Konzek, and W. E. Kennedy,-Jr. 1978. Technology. Safetv, and Costs of Decommissioning a Reference Pressurized Water Reactor Power Station. NUREG/CR-0130, Vols. 1 and 2, prepared for the U.S. Nuclear Regulatory Commission by Pacific Northwest Laboratory, Richland, Washington. 


\section{References}

Westinghouse Hanford Company. 1988. Safetv Analyses

Report for Packaging--Shippingport Reactor Pressure Vessel and Neutron Shield Tank Assembly. Docket Number 87-79515, SSDP-0050, Westinghouse Hanford Company, Richland, Washington.

Wittenbrock, N. G. 1982. Technology. Safetv. and Costs of Decommissioning Nuclear Reactors at Multiple-Reactor Stations. NUREG/CR-1755. Prepared for the U.S. Nuclear Regulatory Commission by Pacific Northwest Laboratory, Richland, Washington.

Wyse, E. J. 1993. "Inductively Coupled Plasma-Mass Spectrometric (ICP-MS) Analysis." PNL-ALO-280, Rev. I. Analytical Chemistry Laboratory Procedure Compendium. PNL-MA-599, Pacific Northwest Laboratory, Richland, Washington. 
Appendix A: Summary of PNL Radiochemical Procedures for 10 CFR Part 61 and Selected Radionuclides 



\section{A.1 Aluminum-26}

Aluminum-26 in aliquots of borosilicate glass from burnable poison rods is measured by instrumental analysis. A triple coincident gamma-ray spectrometric technique is used which measures both 511 -keV gamma photons from positron annihilation and the $1809-\mathrm{keV}$ gamma photon.

\section{A.2 Cadmium-109,-113m}

Cadmium-109,-113m are measured in the Ag-Cd-In alloy of rod cluster control assemblies (RCA) by treating aliquots of nitric acid dissolutions of the alloy with repeated silver chloride precipitate scavenging steps. The supernates from each aliquot are combined and evaporated to dryness. The residues are dissolved in dilute $\mathrm{HBr}$-nitric acid solution and passed through anion columns. The columns are washed and the cadmium is eluted with $2 \mathrm{M}$ nitric acid. The eluates are evaporated to dryness, the residues are dissolved in $\mathrm{NH}_{4} \mathrm{OH}$ and adjusted to $\mathrm{pH} 8$ with $\mathrm{HCl} / \mathrm{NaOH}$. Cadmium sulfide is precipitated with thioacetamide, filtered, and dried. Cadmium-109 is determined by gamma spectrometry and ${ }^{133 n} \mathrm{Cd}$ is determined by beta absorption counting.

\section{A.3 Molybdenum-93}

Molybdenum- 93 is measured in reactor hardware samples by scavenging acid dissolution aliquots repeatedly with $\mathrm{Fe}-\mathrm{Co}-$ $\mathrm{Ni}-\mathrm{Nb}$ hydroxide precipitates from a weak sodium hydroxide solution containing a trace of $\mathrm{NaNO}_{2}$. Molybdenum is then precipitated as lead molybdate. Molybdenum-93 is determined using a thin-window intrinsic germanium detector through measurement of the niobium daughter $\mathrm{x}$ rays. Yields are determined by using ${ }^{99} \mathrm{Mo}$ tracer.

\section{A.4 Nickel-59,-63}

Nickel radionuclides are separated from reactor waste by successive steps of chelating iron with citric acid and precipitating the nickel as dimethylglyoxime. The final dimethylglyoxime precipitate is weighed and mounted for measurement of the ${ }^{59} \mathrm{Ni}$ x-rays with a low energy gamma spectrometer. The precipitate is then carefully dissolved in nitric acid and taken to dryness. The residue is dissolved in weak $\mathrm{HCl}$ and prepared for beta counting in a liquid scintillation spectrometer for ${ }^{63} \mathrm{Ni}$. Yields are determined gravimetrically.

\section{A.5 Niobium-93m,-94}

Niobium-93m,-94 are measured in neutron-activated reactor hardware, after dissolution of the metal samples, by precipitation of niobic oxide in concentrated nitric acid. Both stable niobium carrier and ${ }^{95} \mathrm{Nb}$ tracer are added during the separation. Niobium-94 is measured by gamma-ray spectrometric techniques while ${ }^{93 m} \mathrm{Nb}$ is determined by measuring the niobium $x$-rays using a thin window intrinsic germanium detector. Yields are determined by measuring the ${ }^{95} \mathrm{Nb}$ tracer by gamma-ray spectrometry.

\section{A.7 Transuranics}

Isotopes of americium, curium, and plutonium are separated from acid dissolutions of reactor samples. Aliquots are spiked with ${ }^{242} \mathrm{Pu}$ and ${ }^{243} \mathrm{Am}$ as yield tracers. The solutions are adjusted to $2 \mathrm{M} \mathrm{HNO}_{3}$ and iron and ascorbic acid are added to complex and reduce iron to $\mathrm{Fe}(\mathrm{II})$. TRU-Spec ${ }^{\mathrm{TM}}$ resin columns containing octyl(phenyl)-N, N-diisobutylcarbamoylmethylphosphine oxide are equilibrated with $2 \mathrm{M}$ $\mathrm{HNO}_{3}$ and the samples are passed through the columns. After washing the columns, americium and curium are respectively eluted with $9 \mathrm{M} \mathrm{HCl}$ and $4 \mathrm{M} \mathrm{HCl}$. Plutonium is eluted with $4 \mathrm{M} \mathrm{HCl}^{3 / 40} 1 \mathrm{M}$ hydroquinone. Small amounts of $\mathrm{Nd}$ carrier are added to the plutonium and americiumcurium fractions and the fluorides are precipitated and counted by alpha energy analysis. 


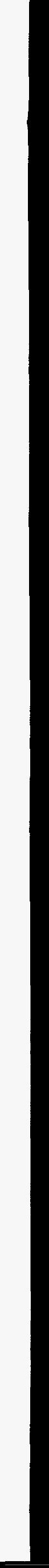




\begin{tabular}{|c|c|}
\hline $\begin{array}{l}\text { U.S. NUCLEAR REGULATORY COMMISSION } \\
\text { BIBLIOGRAPHIC DATA SHEET } \\
\text { (See instructions on the reverse) }\end{array}$ & \multirow{2}{*}{ 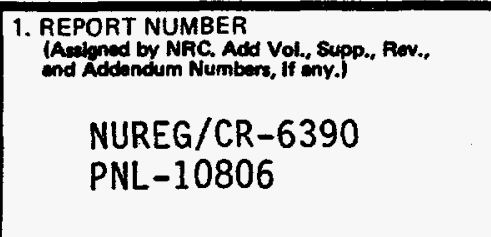 } \\
\hline \multirow{4}{*}{$\begin{array}{l}\text { 2. TITLE AND SUBTITLE } \\
\text { Radiological Characterization of Spent Control Rod Assemblies }\end{array}$} & \\
\hline & 3. DATE REPORT PUBLISHED \\
\hline & \begin{tabular}{|l|l|} 
MONTH & $1995^{\text {YEAR }}$ \\
October & 199
\end{tabular} \\
\hline & $\begin{array}{l}\text { 4. FINOR GRANT NUMBER } \\
\text { B2880 }\end{array}$ \\
\hline \multirow{2}{*}{$\begin{array}{l}\text { 5.AUTHOR(S) } \\
\text { E.A. Lepel, D.E. Robertson, C.W. Thomas, S.L. Pratt, } \\
\text { D.L. Haggard }\end{array}$} & $\begin{array}{l}\text { 6. TYPE OF REPORT } \\
\text { Technical }\end{array}$ \\
\hline & 7. PERIOD COVERED (Inclusive Dates) \\
\hline \multirow{2}{*}{\multicolumn{2}{|c|}{$\begin{array}{l}\text { 8. PERFORMING ORGANIZATION - NAME AND ADDRESS IIf NRC, provide Division, Office or Region, U.S. Nuclear Regulatory Commission, and mailing address; if contractor, provide } \\
\text { name and masiling oddress/ } \\
\text { Pacific Northwest Laboratory } \\
\text { Richl and, WA } 99352\end{array}$}} \\
\hline & \\
\hline \multicolumn{2}{|c|}{ 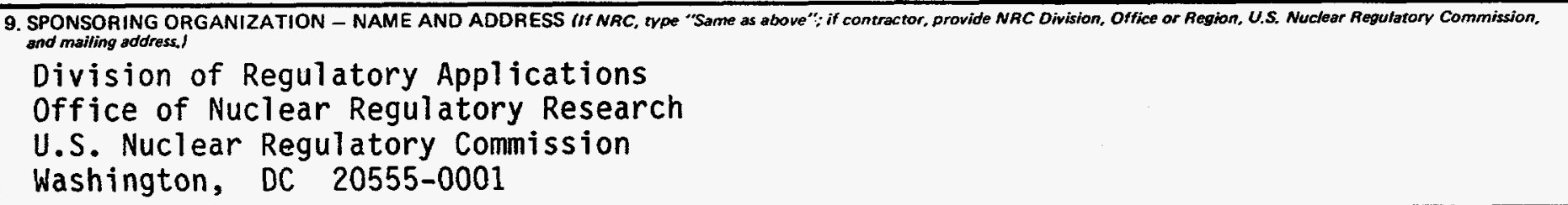 } \\
\hline \multicolumn{2}{|c|}{ 10. SUPPLEMENTARY NOTES } \\
\hline \multicolumn{2}{|c|}{$\begin{array}{l}\text { This ABSTACT (200 words or lest } \\
\text { waste classification assessments, of BWR and PWR spent control rod assemblies. The radionuclide } \\
\text { inventories of these spent control rods were determined by three separate methodologies, including } \\
\text { 1) direct assay techniques, } 2 \text { ) calculational techniques, and } 3 \text { ) by sampling and laboratory radiochemical } \\
\text { analyses. For the BWR control rod blade (CRB) and PWR burnable poison rod assembly (BPRA), }{ }^{60} \mathrm{Co} \\
\text { and }{ }^{63} \mathrm{Ni} \text {, present in the stainless steel cladding, were the most abundant neutron activation products. The } \\
\text { most abundant radionuclide in the PWR rod cluster control assembly (RCCA) was }{ }^{108 m} \mathrm{Ag}(130 \text { yr halflife) } \\
\text { produced in the Ag-In-Cd alloy used as the neutron poison. This radionuclide will be the dominant } \\
\text { contributor to the gamma dose rate for many hundreds of years. The results of the direct assay methods } \\
\text { agree very well ( } \pm 10 \% \text { ) with the sampling/radiochemical measurements. The results of the calculational } \\
\text { methods agreed fairly well with the empirical measurements for the BPRA, but often varied by a factor of } \\
5 \text { to } 10 \text { for the CRB and the RCCA assemblies. If concentration averaging and encapsulation, as allowed } \\
\text { by } 10 \mathrm{CFR} 61.55 \text {, is performed, then each of the entire control assemblies would be classified as Class C } \\
\text { low-level radioactive waste. }\end{array}$} \\
\hline \multirow{6}{*}{$\begin{array}{l}\text { 12. KEY WORDS/DESCR!PTORS (List words or phrases that will assist researchers in locating the report.) } \\
\text { decommisioning, control rods, radionucl ide characterization, } \\
\text { low-level waste }\end{array}$} & $\begin{array}{l}\text { 13. AVAILABILTY STATEMENT } \\
\text { unl imited }\end{array}$ \\
\hline & 14. SECURITY CLASSIFICATION \\
\hline & $\begin{array}{l}\text { (This Pagel } \\
\text { unclass if ied }\end{array}$ \\
\hline & $\begin{array}{l}\text { This Report } \\
\text { unclass if ied }\end{array}$ \\
\hline & 15. NUMBER OF PAGES \\
\hline & 16. PRICE \\
\hline
\end{tabular}

